\title{
Petrology of the high-Mg tonalites and dioritic enclaves of the ca. 2130 Ma Alto Maranhão suite: Evidence for a major juvenile crustal addition event during the Rhyacian orogenesis, Mineiro Belt, southeast Brazil
}

\author{
Luís Antônio Rosa Seixas ${ }^{\mathrm{a}, *}$, Jacques-Marie Bardintzeff ${ }^{\mathrm{b}, \mathrm{c}, \mathrm{d}}$, \\ Ross Stevenson ${ }^{\mathrm{d}}$, Bernard Bonin ${ }^{\mathrm{b}}$ \\ a Departamento de Geologia, Universidade Federal de Ouro Preto, Morro do Cruzeiro, CEP 35400-000 Ouro Preto, Brazil \\ b Université Paris-Sud, Laboratoire IDES, UMR8148, F-91405 Orsay Cedex, France \\ c Université Cergy-Pontoise, IUFM, F-95000 Cergy-Pontoise, France \\ ' GEOTOP Université du Québec à Montréal, P.O. Box 8888, Station Centre Ville, Montréal, Québec H3C 3P8, Canada
}

\section{A R T I C L E I N F O}

\section{Article history:}

Received 3 May 2013

Received in revised form

16 September 2013

Accepted 18 September 2013

Available online 5 October 2013

\section{Keywords:}

Paleoproterozoic

$2130 \mathrm{Ma}$

Mantle wedge melting

High-Mg tonalites and diorites

Brazil

\begin{abstract}
A B S T R A C T
Combined field observations, petrography, mineral chemistry, geochemistry, Nd isotopes and U-Pb zircon data are presented for the ca. 2130 Ma Alto Maranhão suite. The suite, composed by allanite-bearing biotite hornblende tonalites and commingled dioritic mafic magmatic enclaves (MME), occupies an estimated area of $>300 \mathrm{~km}^{2}$ in the southern Quadrilátero Ferrífero region, Minas Gerais, Brazil. Tonalites and commingled MME are medium-K rocks, with high-Mg (Mg-number $\geq 0.46)$ and high-Cr ( $\geq 55 \mathrm{ppm})$ contents. They are also enriched in large-ion lithophile elements (LILE, Sr, Ba), some high-field-strength elements (HFSE, Th, U), and light rare earth elements (REE), but depleted in $\mathrm{Nb}$, Ta, and heavy REE. $T_{\mathrm{DM}}$ model ages for tonalites and MME are similar and range from 2.3 to $2.4 \mathrm{Ga}$. The $\varepsilon_{\mathrm{Nd}}(t)$ values are grouped around chondritic values $(=0 \pm 1.0$ ). Field relations and geochemical data indicate that tonalites and commingled dioritic MME crystallized as synchronous independent magma pulses, with limited mixing. Both magmas are compositionally equivalent to high-Mg andesites in modern subduction zones, implying that the suite was issued from the partial melting of a mantle wedge metasomatised to different degrees by slab-derived melts. Geobarometry (aluminium-in-hornblende) indicates crystallization at mid-crustal depths (i.e. 0.59-0.42 GPa). The igneous suite evolved by fractional crystallization of hornblende, biotite and accessory minerals (zircon, apatite, allanite and Fe-Ti oxide). The ubiquitous occurrence of hornblende and allanite in tonalites and dioritic MME suggests that this mineral pair was largely responsible for the observed changes of light REE/heavy REE and Eu/Eu* ratios within the members of the suite. The geographical extent $\left(>1000 \mathrm{~km}^{2}\right.$ ) and Paleoproterozoic ages of the Alto Maranhão suite (ca. $\left.2130 \mathrm{Ma}\right)$ and associated granitoids of the Mineiro Belt (2.1-2.2 Ga) constitute a major event of juvenile addition to the continental crust in the context of the southern São Francisco craton, and the ca. 2.2-2.1 Ga Rhyacian orogenesis of the South American platform. The age and general geochemical characteristics of the Alto Maranhão suite and its emplacement after a ca. $2.35 \mathrm{Ga}$ juvenile, tholeiitic-source derived high-Al TTG suite, indicate a tectonic setting akin to that of Late-Archaean high-Mg granitoids.
\end{abstract}

(c) 2013 Elsevier B.V. All rights reserved.

\section{Introduction}

Juvenile tonalites are commonly found as members of two main suites in the early earth crustal growth processes (Martin et al., 2005): (i) high-aluminium tonalite-trondhjemite-granodiorite suites (high-Al TTG), and (ii) high-Mg monzodiorite to granodiorite suites. The resemblance of parental magmas of the latter

\footnotetext{
* Corresponding author. Tel.: +55 313559 1600; fax: +55 3135591606 .

E-mail address: luseixas@degeo.ufop.br (L.A.R. Seixas).
}

suites with high-Mg andesitic volcanic rocks of the Setouchi belt, Japan (sanukites, Tatsumi and Ishizaka, 1982), lead to the term sanukitoid to be coined for such suites (Shirey and Hanson, 1984). Both high-Al TTG and high-Mg granitoid suites are particularly representative of Archaean crustal growth processes, with well constrained examples on different cratons (e.g. Amazonian, Oliveira et al., 2011; Pilbara, Smithies and Champion, 2000; Superior province, Stevenson et al., 1999; Karelian, Heilimo et al., 2010; and Darwhar, Moyen et al., 2001). Extensive petrological data demonstrate that high-Al TTG suites derive from partial melting of tholeiitic metabasaltic rocks leaving garnet amphibolite and 
eclogite residues (Drummond and Defant, 1990; Rapp and Watson, 1995; Clemens et al., 2006; Seixas et al., 2012). The wholly more mafic compositions of high-Mg granitoid suites, which commonly include diorites and/or monzodiorites, lead authors to suggest that their parental magmas were derived directly from the melting of enriched mantle peridotite (Stern and Hanson, 1991; Stevenson et al., 1999). High-Mg granitoid suites are enriched in LILE (e.g., $\mathrm{Sr}$ and $\mathrm{Ba}$ ) and show incompatible trace elements content typical of arc-like magmas (Martin et al., 2010). LILE enrichment, in conjunction with depleted mantle-like Nd isotopic ratios, suggests that the mantle source was melted after having been metasomatised by melt and/or fluid (Stern and Hanson, 1991; Stevenson et al., 1999; Lobach-Zhuchenko et al., 2008). Additionally, Rapp et al. (2010) reproduced liquids of sanukitoid composition through melting of mantle peridotite modified by reaction with melts of high-Al TTG composition.

This article presents new field, mineralogical, whole-rock geochemical, U-Pb and Nd-isotope data for a ca. $2130 \mathrm{Ma}$ high-Mg tonalitic suite - the Alto Maranhão suite. This suite is an important component of the Mineiro Belt, a $>1000 \mathrm{~km}^{2}$, mainly $2.2-2.1 \mathrm{Ga}$ orogenic belt bordering the Archaean nucleus of the southern São Francisco craton in the southern Quadrilátero Ferrífero region, Minas Gerais, southeast Brazil (Fig. 1). The age and geochemistry of the Alto Maranhão suite provide new constraints on granitoid petrogenesis and crustal growth during the Rhyacian Orogeny, an important post-Archaean Precambrian crustal growth episode of the South American platform (Cordani and Sato, 1999; Almeida et al., 2000; Condie et al., 2009; Brito Neves, 2011).

\section{Analytical methods}

Microprobe analyses were done at Université Paris-Sud (Centre Scientifique d'Orsay) and Université Pierre et Marie Curie, France, with a CAMECA SX 50. Selected measurements of the major elements and REE contents on allanite, apatite and zircon were performed at the Geosciences Institute, Lausanne University, Switzerland, using a JEOL 8200 Superprobe. The general operating procedures were a $15 \mathrm{kV}$ accelerating voltage, a $20 \mathrm{nA}$ beam current, and using natural and synthetic minerals as standards. Scanning electron microscopy auxiliar to opaque mineralogy investigation was done at Microlab (Ouro Preto Federal University, UFOP), using a JEOL 5510 equipment. Whole rock powder ICP-OES and ICP-MS analysis were obtained at CRPG (Nancy, France), ACME and ACTLABS (both in Canada). The digestion technique employs a lithium metaborate/tetraborate fusion. The resultant molten bead is rapidly digested in a weak nitric acid solution. Zircon U-Pb (ID-TIMS) isotope analyses were made at UnB Geochronology Laboratory (Brasília University, Brazil). Zircon concentrates were extracted from ca. $10 \mathrm{~kg}$ rock sample using a Frantz magnetic separator. Mineral concentrates were hand-picked under a binocular microscope to obtain fractions of similar size, shape and colour. Zircon fractions were dissolved in concentrated $\mathrm{HF}$ and $\mathrm{HNO}_{3}$ (according a ratio of $\mathrm{HF}: \mathrm{HNO}_{3}$ 4:1) using microcapsules in Parr-type bombs. A mixed ${ }^{205} \mathrm{~Pb}-{ }^{235} \mathrm{U}$ spike was used. Chemical extraction followed standard anion exchange technique, using Teflon micro columns, following procedures modified from Krogh (1973). Pb and $U$ were loaded together on single Re filaments with $\mathrm{H}_{3} \mathrm{PO}_{4}$ and $\mathrm{Si}$ gel, and isotopic analyses were carried out on a Finnigan MAT-262 multi-collector mass spectrometer equipped with secondary electron multiplierion counting. Procedure blanks for $\mathrm{Pb}$, at the time of analyses, were better than $20 \mathrm{pg}$. Data reduction and age calculation were performed using the PBDAT (Ludwig, 1993) and ISOPLOT-Ex (Ludwig, 2001a,b) software. Whole rock Sm-Nd isotopic analyses were made at the GEOTOP Research Center (Montreal, Canada). Samples for $\mathrm{Sm}-\mathrm{Nd}$ isotope analyses were dissolved in a $\mathrm{HF}-\mathrm{HNO}_{3}$ mixture in high-pressure Teflon vessels. A ${ }^{150} \mathrm{Nd}-{ }^{149} \mathrm{Sm}$ tracer was added to determine Nd and Sm concentrations. The REE were then purified by cation exchange chromatography, and Sm and $\mathrm{Nd}$ were subsequently separated following the procedure of Richard et al. (1976). The total procedural blanks are less than $150 \mathrm{pg}$. Sm and $\mathrm{Nd}$ analyses were done using a triple filament assembly in a VGSector-54 mass spectrometer. Nd and Sm isotopes were measured in dynamic and static modes, respectively. Repeated measurements of the JNdi- $1 \mathrm{Nd}$ standard (Tanaka et al., 2000) yielded a value of ${ }^{143} \mathrm{Nd} /{ }^{144} \mathrm{Nd}=0.512106 \pm 7(n=37)$. Sm and Nd concentrations and ${ }^{147} \mathrm{Sm} /{ }^{144} \mathrm{Nd}$ ratios have an accuracy of $0.5 \%$ that corresponds to an average error on the initial $\varepsilon_{\mathrm{Nd}}$ value of \pm 0.5 epsilon units.

\section{Sampling and petrography}

The Alto Maranhão suite is located within the Mineiro Belt on the southern edge of the Quadrilátero Ferrífero region of Minas Gerais, southeastern Brazil (Fig. 1c). The geology and classification of the tonalitic, trondhjemitic and granodioritic plutons within the Mineiro Belt were discussed in Seixas et al. (2012). This study concentrates on samples of tonalites and related dioritic MME from the northern part of the belt and near the village of Alto Maranhão (corresponding to T15 and T7 work station in Fig. 1c). They are distinguished from the surrounding granitoid rocks by more mafic compositions, intrinsic mingling relationship with dioritic MME (Fig. 2), and high-Mg suite affinities, as it will be shown in the following sections of this paper. For these reasons, the term Alto Maranhão suite is preferred instead of Alto Maranhão pluton and/or batholith used to designate $2.1 \mathrm{Ga}$ tonalitic rocks in this region (Noce et al., 2000; Seixas et al., 2000). Therefore, this term is used to encompass both tonalites and related dioritic MME. Based on these criteria, the investigated suite is distributed over an estimated minimum area of $300 \mathrm{~km}^{2}$ (Fig. 1c). The main rock-types of the Alto Maranhão suite are modal tonalite for the granitoids and diorite to quartz diorite for the MME (Fig. 2a). They are represented, respectively, by samples T1-T15 and E1-E9 (Fig. 1c). Modal compositions of representative samples are presented in Table 1. From geographical point of view the samples of this study could be grouped in the tonalites and enclaves of the eastern/southeastern sector (E1/E2 and T3/T4+T2/T5); northern sector (E4/E7/E9 and T7/T15 and T10) and the plutonic massive of the samples E3/E5/E6 and T6/T13; northwestern (T1); western (E8 and T8/T14) and the elongated body with the samples T9/T11; and finally the southern sample T12.

Both the tonalites and dioritic MME of the suite share the same mineral components (Table 1). Tonalites are medium-grained, equigranular to seriate, massive to foliated, and commonly contain $>15-35 \mathrm{vol} \%$ [hornblende + biotite], with $\mathrm{Hbl} / \mathrm{Bt}$ ratios ranging from a maximum value of 1.6 (T1) to a lower value of 0.6 , however with most of values between $1.0 \pm 0.2$ (Fig. 2b). K-feldspar (microcline variety) occurs as an interstitial minor phase in some tonalite samples ( $<5 \%$ modal), or is absent (Fig. 2a). Dioritic MME are invariably found in tonalite host-rocks as lenticular, round-to-amoeboid centimetric to decimetric individual enclaves, or as enclave swarms, and/or as tabular to irregularly shaped syn-magmatic metre-sized bodies (e.g. E1/E2 and E8 outcroppings). Tonalites and dioritic MME commonly present mingling structures, as exemplified in Fig. 2d-h. In addition, structures like MME pillowing and tonalitic back-veining are found in a few localities, both indicative of the probable locus for the syn-magmatic dioritic magma conduits intruded into the resident tonalitic chambers (e.g., T3, T13 and E8, Fig. 2f; magma mingling concepts as in Didier and Barbarin, 1991). Dioritic MME are generally fine-grained (average grain size from $\sim 0.1$ up to $1.5 \mathrm{~mm}$ ), more mafic, with $\geq 40$ up to $70 \mathrm{vol} \%$ 


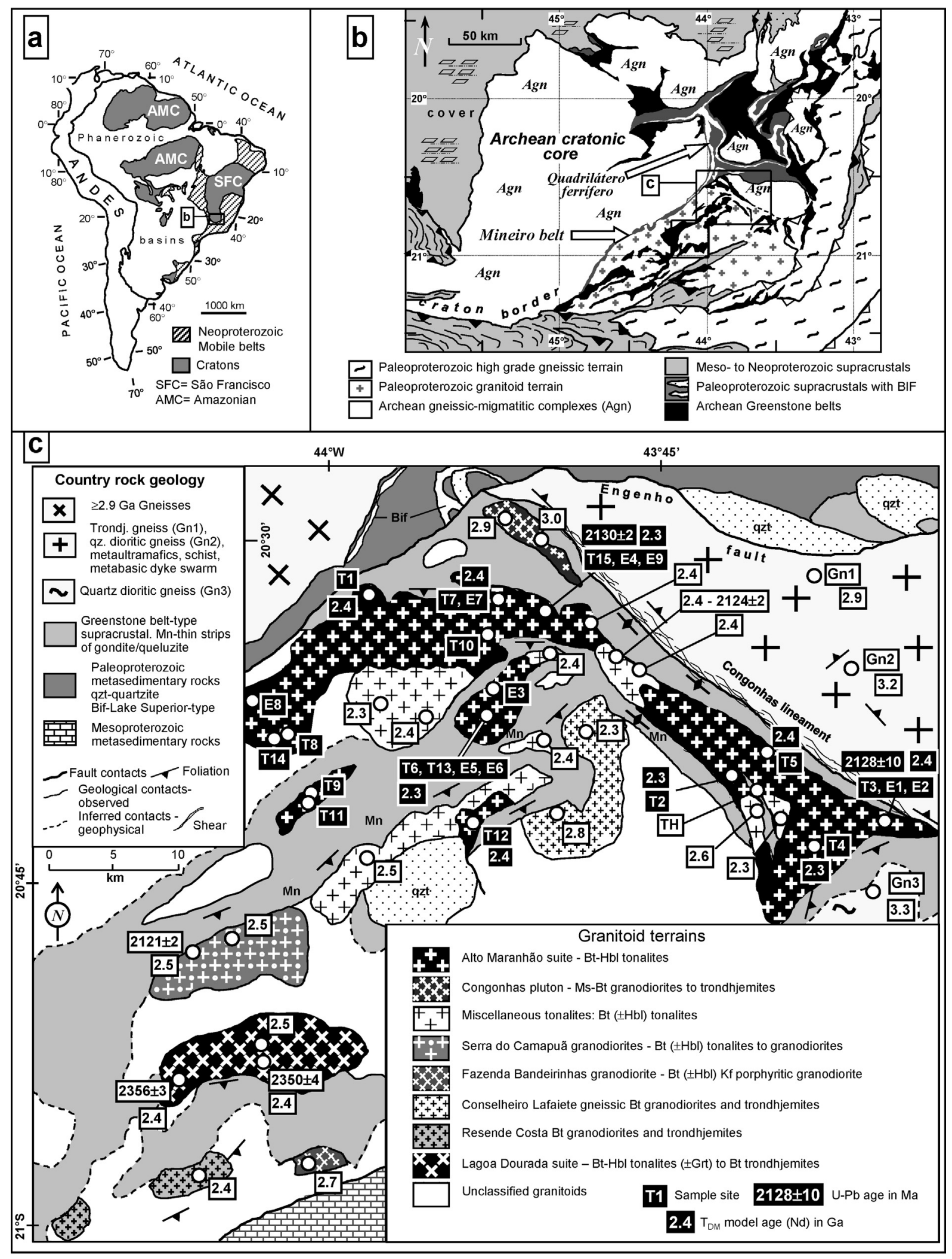

Fig. 1. Location of Paleoproterozoic granitoids of Mineiro Belt in the São Francisco craton (SFC). Adapted from Seixas et al. (2012) and references therein. (a) The SFC in relation to the major tectonic units of South America. (b) Location of the Mineiro Belt within the southern SFC. (c) Sampling localities of tonalites (T1-T15) and dioritic MME (E1-E9) investigated in this study. U-Pb zircon crystallization ages of selected granitoid suites (in million years, Ma) and Nd model ages (in billion years, Ga) are shown within boxes. The Alto Maranhão locality lies between T15 and T7 sampling stations. 
(a)

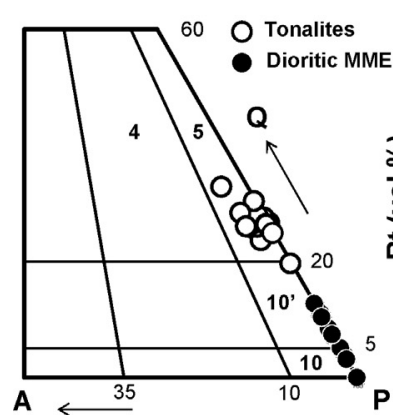

(b)

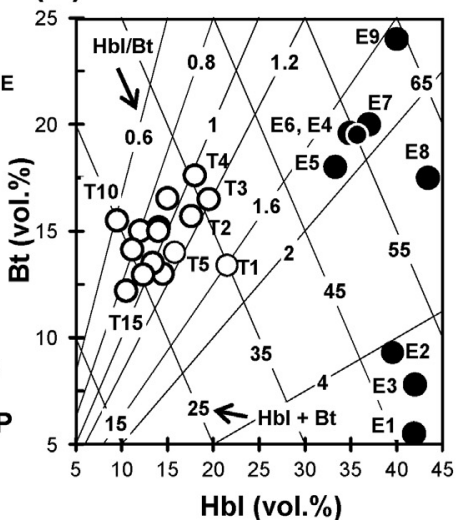

(c)

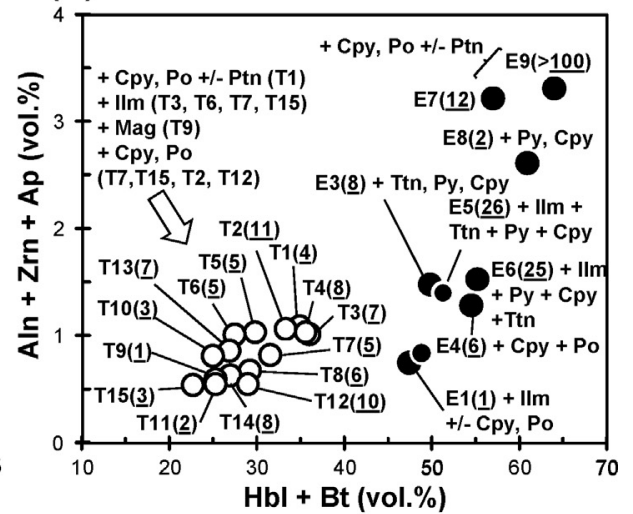

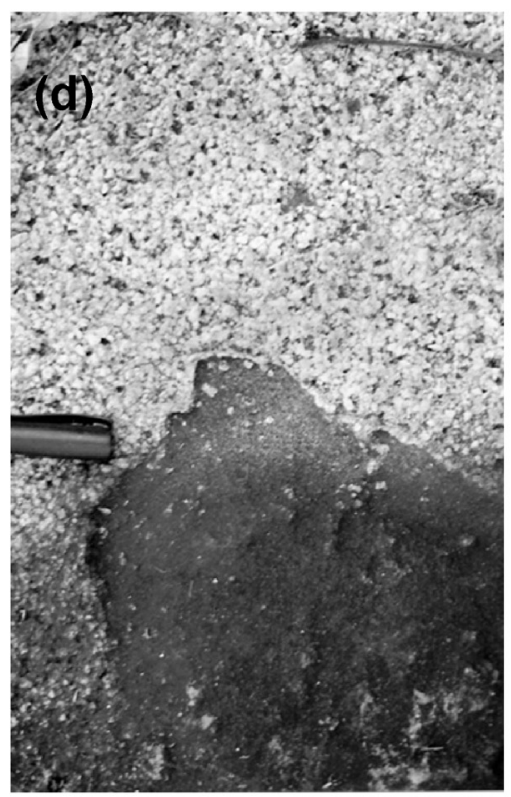
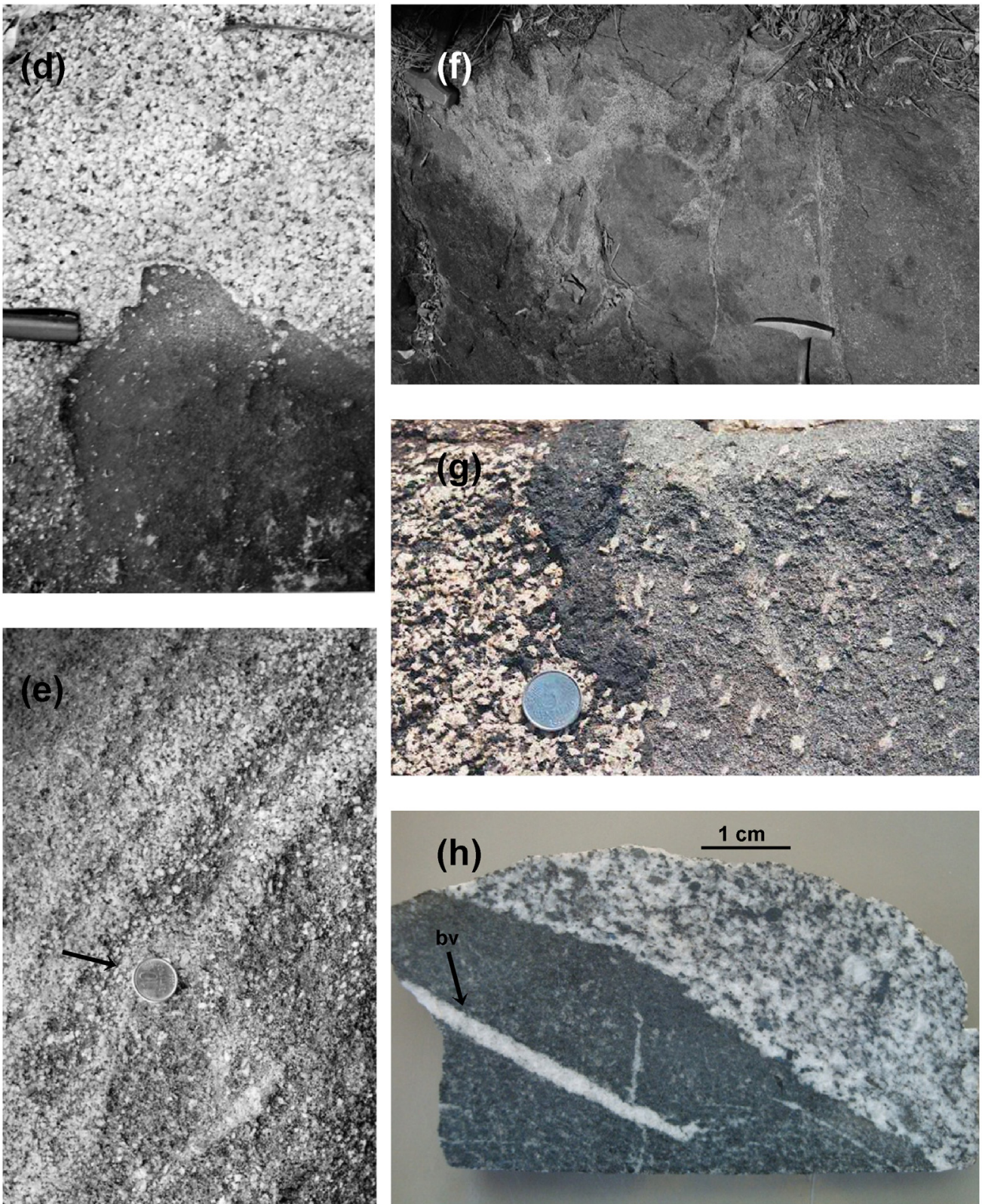

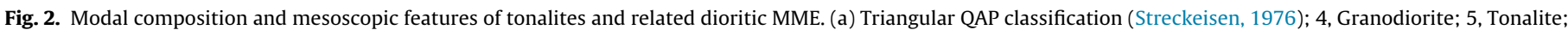

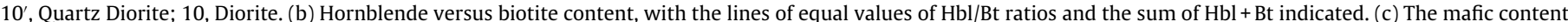

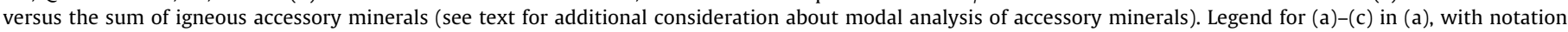

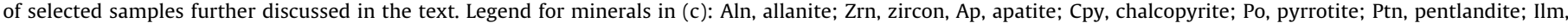

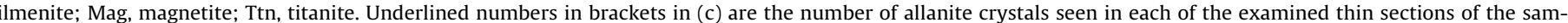

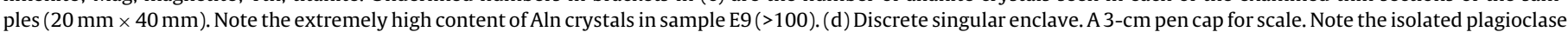


Table 1

Modal composition of selected samples of the investigated granitoids and MME, Alto Maranhão suite.

\begin{tabular}{|c|c|c|c|c|c|c|c|c|c|c|c|c|c|c|c|}
\hline \multirow{2}{*}{$\begin{array}{l}\text { Sector }^{\mathrm{a}} \\
\text { Sample }\end{array}$} & \multicolumn{2}{|c|}{ Southeastern } & \multicolumn{3}{|c|}{ Centre-south } & \multicolumn{2}{|c|}{ Northern } & \multicolumn{2}{|c|}{ Northern } & \multicolumn{2}{|c|}{ Western } & \multirow{2}{*}{$\begin{array}{l}\text { NW } \\
\text { T1 }\end{array}$} & \multirow{2}{*}{$\begin{array}{l}\text { Eastern } \\
\text { T2 }\end{array}$} & \multirow{2}{*}{$\begin{array}{l}\text { Western } \\
\text { T9 }\end{array}$} & \multirow{2}{*}{$\begin{array}{l}\text { South } \\
\text { T12 }\end{array}$} \\
\hline & E1 & T3 & E3 & E5 & T6 & E7 & $\mathrm{T} 7$ & E9 & T15 & E8 & $\mathrm{T} 8$ & & & & \\
\hline Qtz & 2.0 & 16.8 & 1.5 & 5.0 & 17.0 & 4.0 & 19.0 & 2.3 & 25.0 & 0.0 & 18.0 & 12.5 & 17.5 & 17.9 & 21.0 \\
\hline $\mathrm{Pl}$ & 49.0 & 43.5 & 46.4 & 40.5 & 51.0 & 34.3 & 46.0 & 28.6 & 48.5 & 38.5 & 50.0 & 51.1 & 46.0 & 54.0 & 48.0 \\
\hline $\mathrm{Kf}$ & 0.0 & 2.0 & 0.0 & 0.0 & 1.9 & 0.0 & 2.0 & 0.0 & 2.5 & 0.0 & 0.0 & 0.0 & 0.0 & 0.0 & 0.0 \\
\hline $\mathrm{Hbl}$ & 41.9 & 19.5 & 42.0 & 33.3 & 14.5 & 37.0 & 15.0 & 40.0 & 10.5 & 43.4 & 14.1 & 21.5 & 17.6 & 12.4 & 14.0 \\
\hline $\mathrm{Bt}$ & 5.5 & 16.5 & 7.8 & 18.0 & 13.0 & 20.0 & 16.5 & 24.0 & 12.2 & 17.5 & 15.2 & 13.4 & 15.7 & 13.0 & 15.0 \\
\hline Class. & bhd & bht & bhd & bhqd & bht & bhqd & hbt & bhqd & hbt & hbd & hbt & bht & bht & hbt & hbt \\
\hline $\mathrm{Hbl}+\mathrm{Bt}$ & 47.4 & 36.0 & 49.8 & 51.3 & 27.5 & 57.0 & 31.5 & 64.0 & 22.7 & 60.9 & 29.2 & 34.9 & 33.3 & 25.3 & 29.0 \\
\hline $\mathrm{Hbl} / \mathrm{Bt}$ & 7.6 & 1.2 & 5.4 & 1.9 & 1.1 & 1.9 & 0.9 & 1.7 & 0.9 & 2.5 & 0.9 & 1.6 & 1.1 & 1.0 & 0.9 \\
\hline \multicolumn{16}{|c|}{ Accessory minerals } \\
\hline $\mathrm{Zrn}^{*}$ & 0.03 & 0.05 & 0.05 & 0.05 & 0.04 & 0.08 & 0.02 & 0.11 & 0.03 & 0.06 & 0.04 & 0.04 & 0.05 & 0.04 & 0.04 \\
\hline Ap* & 0.65 & 0.75 & 1.30 & 1.10 & 0.80 & 2.80 & 0.68 & 2.60 & 0.45 & 2.30 & 0.57 & 0.90 & 0.75 & 0.50 & 0.45 \\
\hline Aln* & 0.07 & 0.22 & 0.13 & 0.25 & 0.17 & 0.34 & 0.12 & 0.60 & 0.06 & 0.26 & 0.07 & 0.15 & 0.27 & 0.06 & 0.07 \\
\hline Aln (M) & $\mathrm{P}$ & A & A & A & A & A & A & A & $\mathrm{C}$ & $\mathrm{P}$ & A & $\mathrm{C}$ & A & $\mathrm{P}$ & A \\
\hline Aln $(n)$ & 1 & 7 & 8 & 26 & 5 & 12 & 5 & 200 & 3 & 1 & 6 & 4 & 11 & 1 & 10 \\
\hline $\begin{array}{l}\text { Euh. Ttn } \\
\text { Opaque m }\end{array}$ & no & no & $\mathrm{P}$ & $\mathrm{C}$ & $\mathrm{C}$ & no & no & no & no & no & no & no & no & C & no \\
\hline $\mathrm{Op}(\mathrm{M})$ & A & A & A & $\mathrm{P}$ & $\mathrm{P}$ & A & $\mathrm{P}$ & A & $\mathrm{P}$ & A & $\mathrm{P}$ & A & $\mathrm{P}$ & A & $\mathrm{P}$ \\
\hline Op phase & $\mathrm{Ilm}$ & $\mathrm{Ilm}$ & $\mathrm{S} 1$ & $\mathrm{Ilm}+\mathrm{S} 1$ & $\mathrm{Ilm}$ & $\mathrm{S} 2$ & S3 & $\mathrm{S} 2$ & S3 & $\mathrm{S} 1^{*}$ & $\mathrm{~S} 2$ & $\mathrm{~S} 2$ & S3 & Mag & S3 \\
\hline $\mathrm{OP}(n)$ & 186 & 286 & 156 & $<15$ & $<15$ & 250 & $<15$ & 285 & $<15$ & 200 & $<15$ & 58 & $<15$ & 51 & 8 \\
\hline
\end{tabular}

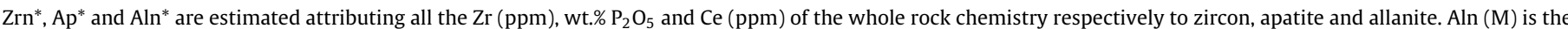

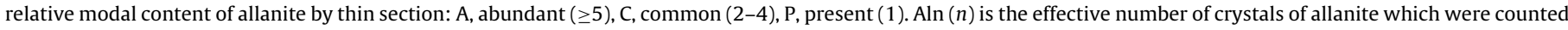

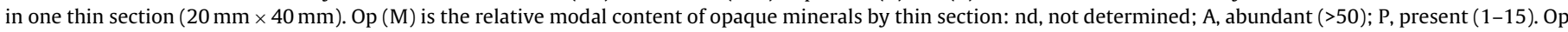

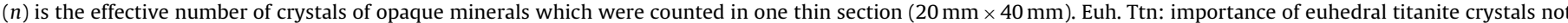

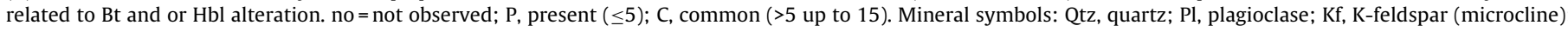

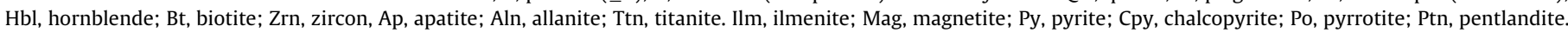

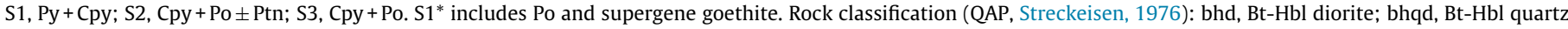
diorite; bht, Bt-Hbl tonalite; hbt, Hbl-Bt tonalite.

a Reference with the sample localities in Fig. 1c. Note couples granitoids/enclaves are presented together.

[hornblende + biotite], presenting $\mathrm{Hbl} / \mathrm{Bt}$ ratios from $\sim 7.6$ (E1) to 1.5 (Fig. 2b) and with subordinate or no quartz (Fig. 2a). Eventually some amphibole-rich clots associated to the MME attain an ultramafic composition (e.g. centre of Fig. 2 g). It can be noted that, excepting for the enclaves E1, E2 and E3, which are richer in hornblende, for all the other enclaves their vol.\% biotite content is greater than the biotite content of the tonalites (Fig. 2b). Zircon, apatite and allanite are ubiquitous accessory igneous minerals and were found in each one of the samples of this study. An approximative estimative of the relative proportion of the sum of these three accessory minerals between enclaves and tonalites is shown in Fig. 2c. The estimative is based on the chemical composition of the rocks, attributing to these minerals respectively all the content of $\mathrm{Zr}(\mathrm{ppm})$, wt.\% $\mathrm{P}_{2} \mathrm{O}_{5}$ and $\mathrm{Ce}(\mathrm{ppm})$. From this picture, excepting samples E1/E2, all other enclaves must be comparatively richer than the tonalites in these accessory minerals. The relatively higher dimension of allanite than the other phases (i.e., apatite and zircon) permits to test this assertive by counting the number of crystals by thin section $(20 \mathrm{~mm} \times 40 \mathrm{~mm})$. The results of modal counting of allanite crystals are shown in Fig. $2 \mathrm{c}$ and corroborates the estimated higher content of allanite in the enclaves based in the Ce (ppm) content of the rocks, with notably high vol.\% of allanite for some samples (e.g. samples E7, E5, E6 and E9, with respectively $12,25,26$ and $>100$ allanite crystals in the same thin section). In addition, sulphides, Fe-Ti oxides, titanite and epidote are variably distributed between the samples (Fig. 2c, see also Section 4.1.).

\section{Results}

\subsection{Mineral chemistry}

Representative mineral compositions of the Alto Maranhão suite are presented in Table 2. Microprobe data were obtained from tonalite samples T1, T3, T4, T5, T7, T9 and T15, and from dioritic MME samples E4, E5, E7, and E9 (Fig. 1c). The main body of the data was presented in Seixas (2000). A synthesis of compositional and/or textural features of the various minerals analysed is shown in Fig. 3. Amphibole is the main mafic mineral of the suite. It forms euhedral, frequently twinned crystals, partially replaced by late magmatic biotite. The main composition of amphibole is magnesiohornblende $\left[\mathrm{Mg} /\left(\mathrm{Mg}+\mathrm{Fe}^{2+}\right) \sim 0.55-0.72\right]$, with normal and reverse zonation (Fig. 3a, nomenclature after Leake et al., 1997). Locally, magnesiohornblende is partially to wholly recrystallized to retromorphic actinolite (Fig. 2a). Application of aluminium-in-hornblende geobarometer (Schmidt, 1992) to the magnesiohornblende compositions presenting the suitable range of $\mathrm{Fe} / \mathrm{Fe}+\mathrm{Mg}$ of $0.40-0.65$ (Anderson and Smith, 1995 - compositions which correspond to the amphiboles with Mg-number $\leq 0.61$ in Fig. 3a) indicates that the tonalitic magma crystallized under pressures varying from 0.59 to $0.42 \mathrm{GPa}$ (Table 2). These pressures are compatible to mid-crustal depths. Biotite is a latter phase in relation to magnesiohornblende, with relatively homogeneous compositions and $\mathrm{Mg} /\left(\mathrm{Mg}+\mathrm{Fe}^{2+}\right) \sim 0.55$ (Fig. 3b). The biotite composition plots in the field of calc-alkaline

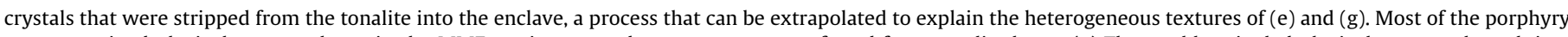

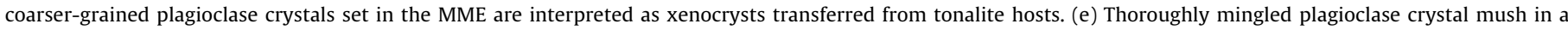

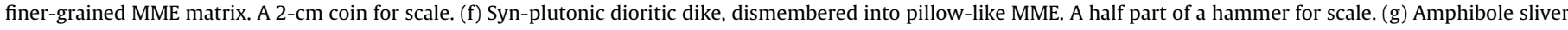

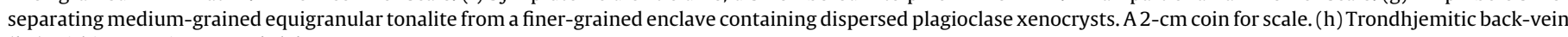
(bv) within MME in a sawed slab. 
Table 2

Selected mineral compositions from the tonalites and dioritic MME, Alto Maranhão suite. ${ }^{\text {a }}$

\begin{tabular}{|c|c|c|c|c|c|c|c|c|c|c|c|c|c|c|c|c|c|c|c|}
\hline \multirow{2}{*}{$\begin{array}{l}\mathrm{Bt} \\
\mathrm{Ox} .\end{array}$} & & \multirow{2}{*}{\multicolumn{3}{|c|}{$\begin{array}{l}\mathrm{Hbl} \\
\mathrm{Ox} .\end{array}$}} & \multicolumn{3}{|l|}{ Plg } & \multicolumn{6}{|l|}{ Aln } & \multicolumn{3}{|l|}{ Ap } & \multicolumn{3}{|l|}{$\mathrm{Zrn}$} \\
\hline & & & & & Oxide & Core & Rim & Oxide & Core & Rim & Cation & Core & Rim & Oxide & Acicul. & Short & Oxide & Core & Rim \\
\hline $\mathrm{SiO}_{2}$ & 36.41 & $\mathrm{SiO}_{2}$ & 44.77 & 46.40 & $\mathrm{SiO}_{2}$ & 62.5 & 64.2 & $\mathrm{SiO}_{2}$ & 30.37 & 30.91 & $\mathrm{Si}$ & 3.000 & 2.983 & $\mathrm{SiO}_{2}$ & 0.75 & 0.17 & $\mathrm{SiO}_{2}$ & 32.60 & 32.70 \\
\hline $\mathrm{TiO}_{2}$ & 1.02 & $\mathrm{TiO}_{2}$ & 0.65 & 1.16 & $\mathrm{Al}_{2} \mathrm{O}_{3}$ & 24.5 & 23.6 & $\mathrm{TiO}_{2}$ & 1.17 & 0.78 & $\mathrm{Al}^{\mathrm{IV}}$ & 0.000 & 0.017 & $\mathrm{FeO}_{\mathrm{t}}$ & 0.04 & 0.59 & $\mathrm{ZrO}_{2}$ & 66.10 & 64.19 \\
\hline $\mathrm{Al}_{2} \mathrm{O}_{3}$ & 17.55 & $\mathrm{Al}_{2} \mathrm{O}_{3}$ & 10.53 & 8.75 & $\mathrm{FeO}_{\mathrm{t}}$ & 0.0 & 0.1 & $\mathrm{ZrO}_{2}$ & 0.00 & 0.00 & Tot. $^{\text {IV }}$ & 3.000 & 3.000 & $\mathrm{MnO}$ & 0.03 & 0.03 & $\mathrm{HfO}_{2}$ & 0.87 & 2.02 \\
\hline $\mathrm{FeO}_{\mathrm{t}}$ & 16.74 & $\mathrm{FeO}_{\mathrm{t}}$ & 17.97 & 16.16 & $\mathrm{CaO}$ & 5.29 & 4.11 & $\mathrm{Al}_{2} \mathrm{O}_{3}$ & 15.29 & 16.77 & $\mathrm{Al}^{\mathrm{VI}}$ & 1.779 & 1.890 & $\mathrm{CaO}$ & 54.53 & 54.62 & $\mathrm{Al}_{2} \mathrm{O}_{3}$ & 0.17 & 0.04 \\
\hline $\mathrm{MnO}$ & 0.24 & $\mathrm{MnO}$ & 0.40 & 0.53 & $\mathrm{Na}_{2} \mathrm{O}$ & 7.86 & 9.41 & $\mathrm{Fe}_{2} \mathrm{O}_{3}{ }^{*}$ & 1.63 & 2.56 & $\mathrm{Ti}$ & 0.087 & 0.056 & $\mathrm{Na}_{2} \mathrm{O}$ & 0.01 & 0.02 & $\mathrm{FeO}_{\mathrm{t}}$ & 0.17 & 0.14 \\
\hline $\mathrm{MgO}$ & 12.13 & $\mathrm{MgO}$ & 9.03 & 11.13 & $\mathrm{~K}_{2} \mathrm{O}$ & 0.19 & 0.05 & $\mathrm{FeO}^{*}$ & 9.67 & 8.73 & $\mathrm{Zr}$ & 0.000 & 0.000 & $\mathrm{P}_{2} \mathrm{O}_{5}$ & 40.84 & 41.64 & $\mathrm{Y}_{2} \mathrm{O}_{3}$ & 0.29 & 0.21 \\
\hline $\mathrm{CaO}$ & 0.16 & $\mathrm{CaO}$ & 11.49 & 11.59 & Total & 100.4 & 101.4 & $\mathrm{MnO}$ & 0.28 & 0.27 & $\mathrm{Fe}^{3+}$ & 0.121 & 0.185 & $\mathrm{Y}_{2} \mathrm{O}_{3}$ & 0.73 & 0.13 & $\mathrm{La}_{2} \mathrm{O}_{3}$ & nd & nd \\
\hline $\mathrm{Na}_{2} \mathrm{O}$ & 0.04 & $\mathrm{Na}_{2} \mathrm{O}$ & 0.93 & 1.08 & $\% A n$ & 26.8 & 19.4 & $\mathrm{MgO}$ & 1.11 & 0.93 & $\mathrm{Fe}^{2+}$ & 0.799 & 0.705 & $\mathrm{La}_{2} \mathrm{O}_{3}$ & $<0.19$ & na & $\mathrm{Ce}_{2} \mathrm{O}_{3}$ & 0.06 & nd \\
\hline $\mathrm{K}_{2} \mathrm{O}$ & 9.42 & $\mathrm{~K}_{2} \mathrm{O}$ & 1.00 & 0.73 & & & & $\mathrm{CaO}$ & 10.84 & 11.70 & $\mathrm{Mn}$ & 0.024 & 0.022 & $\mathrm{Ce}_{2} \mathrm{O}_{3}$ & 0.29 & $<0.06$ & $\mathrm{Pr}_{2} \mathrm{O}_{3}$ & nd & nd \\
\hline Total & 93.71 & Total & 96.77 & 97.56 & $\mathrm{Ilm}$ & & & $\mathrm{ThO}_{2}$ & 2.08 & 1.43 & $\mathrm{Mg}$ & 0.163 & 0.134 & $\mathrm{Nd}_{2} \mathrm{O}_{3}$ & 0.51 & 0.17 & $\mathrm{Nd}_{2} \mathrm{O}_{3}$ & nd & nd \\
\hline $\mathrm{Si}$ & 5.567 & $\mathrm{Si}$ & 6.729 & 6.844 & $\mathrm{SiO}_{2}$ & 0.01 & 0.02 & $\mathrm{Y}_{2} \mathrm{O}_{3}$ & 0.10 & 0.27 & Tot. M & 2.973 & 2.992 & $\mathrm{Sm}_{2} \mathrm{O}_{3}$ & 0.24 & nd & $\mathrm{Sm}_{2} \mathrm{O}_{3}$ & nd & nd \\
\hline $\mathrm{Al}^{\mathrm{IV}}$ & 2.433 & $\mathrm{Al}^{\mathrm{IV}}$ & 1.271 & 1.156 & $\mathrm{TiO}_{2}$ & 52.14 & 52.48 & $\mathrm{La}_{2} \mathrm{O}_{3}$ & 5.53 & 4.53 & $\mathrm{Ca}$ & 1.147 & 1.210 & $\mathrm{Eu}_{2} \mathrm{O}_{3}$ & 0.14 & na & $\mathrm{Eu}_{2} \mathrm{O}_{3}$ & nd & nd \\
\hline $\mathrm{Al}^{\mathrm{VI}}$ & 0.730 & $\mathrm{Al}^{\mathrm{VI}}$ & 0.594 & 0.364 & $\mathrm{Al}_{2} \mathrm{O}_{3}$ & 0.03 & 0.04 & $\mathrm{Ce}_{2} \mathrm{O}_{3}$ & 11.42 & 9.90 & $\mathrm{Y}$ & 0.005 & 0.014 & $\mathrm{Gd}_{2} \mathrm{O}_{3}$ & 0.31 & nd & $\mathrm{Gd}_{2} \mathrm{O}_{3}$ & nd & nd \\
\hline $\mathrm{Ti}$ & 0.117 & $\mathrm{Ti}$ & 0.073 & 0.129 & $\mathrm{FeO}_{\mathrm{t}}$ & 43.09 & 42.63 & $\mathrm{Pr}_{2} \mathrm{O}_{3}$ & 1.07 & 1.24 & $\mathrm{La}$ & 0.201 & 0.161 & $\mathrm{Dy}_{2} \mathrm{O}_{3}$ & $<0.02$ & na & $\mathrm{MgO}$ & 0.03 & nd \\
\hline $\mathrm{Fe}_{\mathrm{t}}$ & 2.141 & $\mathrm{Fe}^{3+}$ & 0.368 & 0.427 & $\mathrm{MnO}$ & 3.51 & 3.80 & $\mathrm{Nd}_{2} \mathrm{O}_{3}$ & 3.87 & 4.46 & $\mathrm{Ce}$ & 0.413 & 0.350 & $\mathrm{~F}$ & 2.61 & 2.53 & $\mathrm{Th}_{2} \mathrm{O}_{3}$ & nd & nd \\
\hline Mn & 0.032 & $\mathrm{Fe}^{2+}$ & 1.891 & 1.566 & $\mathrm{MgO}$ & 0.16 & 0.17 & $\mathrm{Sm}_{2} \mathrm{O}_{3}$ & 0.25 & 0.32 & $\operatorname{Pr}$ & 0.039 & 0.044 & $\mathrm{Cl}$ & nd & 0.06 & $\mathrm{UO}_{2}$ & nd & nd \\
\hline $\mathrm{Mg}$ & 2.765 & $\mathrm{Mn}$ & 0.051 & 0.066 & $\mathrm{CaO}$ & 0.36 & 0.39 & $\mathrm{Gd}_{2} \mathrm{O}_{3}$ & 0.90 & 1.06 & $\mathrm{Nd}$ & 0.137 & 0.154 & $-\mathrm{O}=\mathrm{Cl}, \mathrm{F}$ & 1.10 & 1.08 & Total & 100.29 & 99.30 \\
\hline Tot.Y & 5.784 & $\mathrm{Mg}$ & 2.023 & 2.448 & Total & 99.30 & 99.53 & $\mathrm{Dy}_{2} \mathrm{O}_{3}$ & 0.00 & 0.00 & $\mathrm{Sm}$ & 0.008 & 0.011 & Total & 100.12 & 98.94 & $\mathrm{RE}+\mathrm{Y}_{2} \mathrm{O}_{3} \%$ & 0.36 & 0.21 \\
\hline $\mathrm{Ca}$ & 0.027 & $\mathrm{Ca}$ & 1.850 & 1.830 & $\mathrm{Si}$ & 0.000 & 0.001 & Total $^{*}$ & 95.58 & 95.88 & Gd & 0.029 & 0.034 & $\mathrm{RE}_{2} \mathrm{O}_{3} \%$ & 2.41 & 0.48 & $\mathrm{Si}$ & 3.984 & 4.040 \\
\hline $\mathrm{Na}$ & 0.011 & $\mathrm{Na}$ & 0.150 & 0.170 & $\mathrm{Ti}$ & 0.994 & 0.998 & $\mathrm{RE}_{2} \mathrm{O}_{3} \%$ & 23.14 & 21.78 & Dy & 0.000 & 0.000 & $\mathrm{P}$ & 2.957 & 3.019 & $\mathrm{Al}^{\mathrm{IV}}$ & 0.016 & 0.000 \\
\hline K & 1.837 & $\mathrm{Na}$ & 0.121 & 0.140 & $\mathrm{Al}$ & 0.001 & 0.001 & $\mathrm{Ce}_{\mathrm{N}} / \mathrm{Y}_{\mathrm{N}}$ & 270 & 89 & Th & 0.047 & 0.031 & $\mathrm{Si}$ & 0.064 & 0.014 & $\mathrm{Al}^{\mathrm{VI}}$ & 0.009 & 0.005 \\
\hline Tot.X & 1.874 & $\mathrm{~K}$ & 0.192 & 0.138 & $\mathrm{Fe}^{3+}$ & 0.010 & 0.001 & $\mathrm{Nd}_{\mathrm{N}} / \mathrm{Gd}_{\mathrm{N}}$ & 1.8 & 1.8 & Tot. A & 2.027 & 2.008 & $\mathrm{Fe}^{2+}$ & 0.003 & 0.042 & $\mathrm{Zr}$ & 3.939 & 3.867 \\
\hline Tot. & 15.66 & Tot. & 15.31 & 15.28 & $\mathrm{Fe}^{2+}$ & 0.903 & 0.900 & & & & Tot. $^{\mathrm{VI}}$ & 5.000 & 5.000 & $\mathrm{Mn}$ & 0.002 & 0.002 & $\mathrm{Hf}$ & 0.030 & 0.071 \\
\hline \multirow[t]{14}{*}{ Mg\# } & 0.56 & Mg\# & 0.52 & 0.61 & $\mathrm{Mn}$ & 0.075 & 0.081 & & & & Tot. RE & 0.833 & 0.767 & $\mathrm{Ca}$ & 4.996 & 5.012 & $\mathrm{Fe}_{\mathrm{t}}$ & 0.017 & 0.015 \\
\hline & & $\mathrm{Al}_{\mathrm{t}}$ & 1.865 & 1.520 & $\mathrm{Mg}$ & 0.006 & 0.006 & & & & Cations & 8.000 & 8.000 & $\mathrm{Na}$ & 0.001 & 0.003 & $\mathrm{Y}$ & 0.019 & 0.014 \\
\hline & & $\mathrm{P}_{\mathrm{GPa}}$ & 0.59 & 0.42 & $\mathrm{Ca}$ & 0.010 & 0.011 & & & & $\mathrm{Sm} / \mathrm{Nd}$ & 0.062 & 0.070 & $\mathrm{Y}$ & 0.033 & 0.006 & $\mathrm{La}$ & - & - \\
\hline & & & & & Tot. & 2.000 & 2.000 & & & & Ps & 0.06 & 0.09 & $\mathrm{La}$ & $<0.006$ & & $\mathrm{Ce}$ & 0.003 & - \\
\hline & & & & & $\mathrm{FeO}^{*}$ & 42.61 & 42.58 & & & & & & & $\mathrm{Ce}$ & 0.009 & $<0.00$ & $\operatorname{Pr}$ & - & - \\
\hline & & & & & $\mathrm{Fe}_{2} \mathrm{O}_{3}$ & 0.53 & 0.06 & & & & & & & $\mathrm{Nd}$ & 0.015 & 0.005 & $\mathrm{Nd}$ & - & - \\
\hline & & & & & Total* & 99.35 & 99.54 & & & & & & & $\mathrm{Sm}$ & 0.007 & & $\mathrm{Sm}$ & - & - \\
\hline & & & & & $\mathrm{X}_{\mathrm{ILM}}$ & 0.995 & 0.999 & & & & & & & $\mathrm{Eu}$ & 0.004 & & Eu & - & - \\
\hline & & & & & $\mathrm{X}_{\mathrm{HEM}}$ & 0.005 & 0.001 & & & & & & & Gd & 0.009 & - & $\mathrm{Gd}$ & - & - \\
\hline & & Tot.Cat. & 8.023 & 8.093 & $\mathrm{Mg}$ & 0.006 & - & & & & & & & & & & & & \\
\hline & & Tot.RE & 0.084 & 0.013 & Th & - & - & & & & & & & & & & & & \\
\hline & & $\mathrm{F}$ & 0.706 & 0.684 & $\mathrm{U}$ & - & - & & & & & & & & & & & & \\
\hline & & $\mathrm{Cl}$ & & 0.008 & Tot.Cations & 8.023 & 8.012 & & & & & & & & & & & & \\
\hline & & $\mathrm{OH}^{*}$ & 0.293 & 0.307 & Tot. RE & 0.022 & 0.014 & & & & & & & & & & & & \\
\hline
\end{tabular}

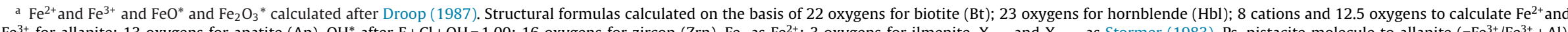
$\mathrm{Fe}^{3+}$ for allanite; 13 oxygens for apatite (Ap), $\mathrm{OH}^{*}$ after $\mathrm{F}+\mathrm{Cl}+\mathrm{OH}=1.00 ; 16$ oxygens for zircon ( $\left.\mathrm{Zrn}\right), \mathrm{Fe}_{\mathrm{t}}$ as $\mathrm{Fe}^{2+} ; 3$ oxygens for ilmenite, $\mathrm{X}_{\mathrm{IM}}$ and $\mathrm{X}_{\mathrm{H}}$

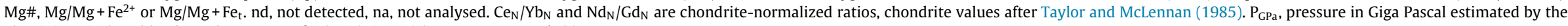
aluminium-in-hornblende geobarometer of Schmidt $(1992)\left(\mathrm{P}_{\mathrm{Kb}}=-3.01+4.76^{*} \mathrm{Al}_{\mathrm{t}}\right)$. 
(a) Amphibole

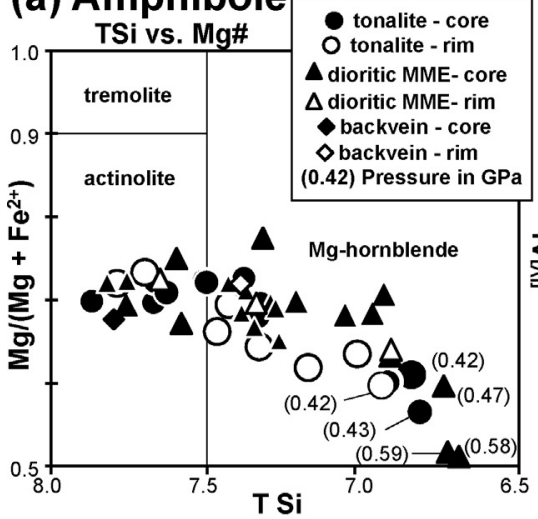

(c) Plagioclase

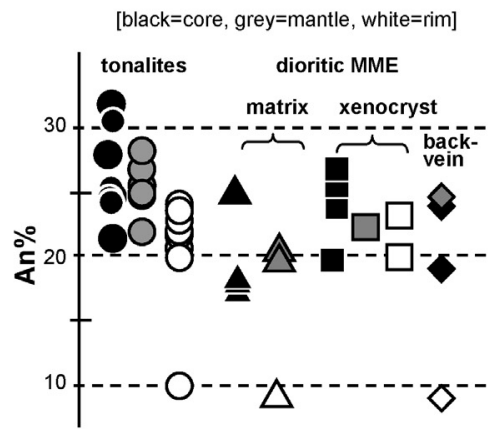

(e) Ilmenite
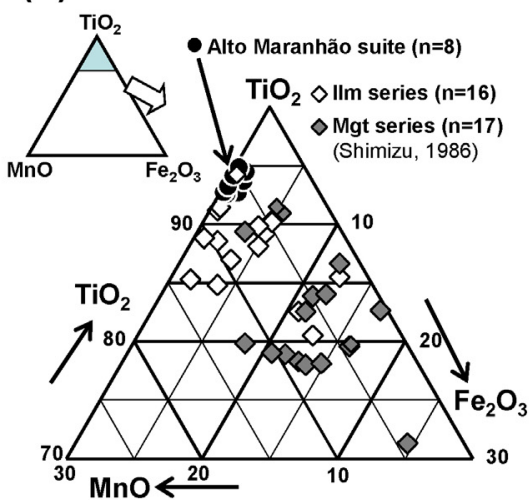

(h) Ttn+Qtz symplectite

[Backscattered image]

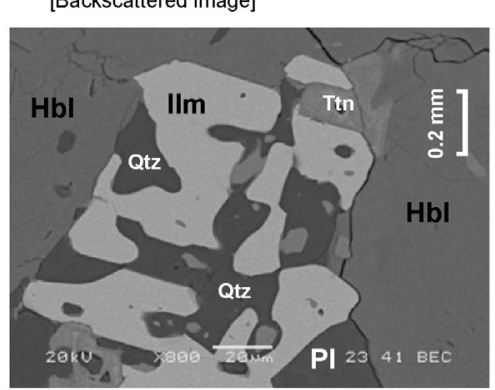

(b) Biotite
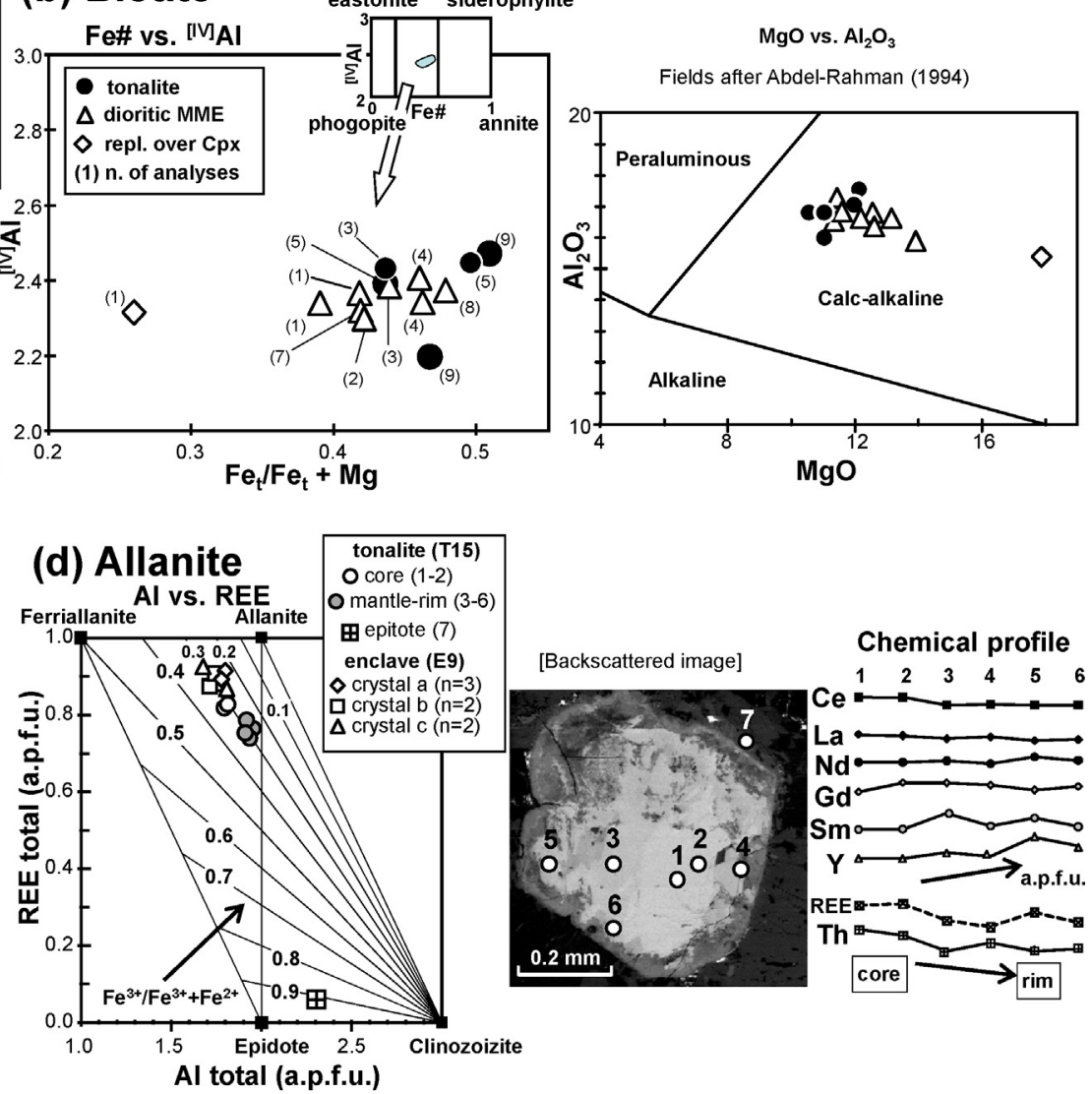

(f) Zircon
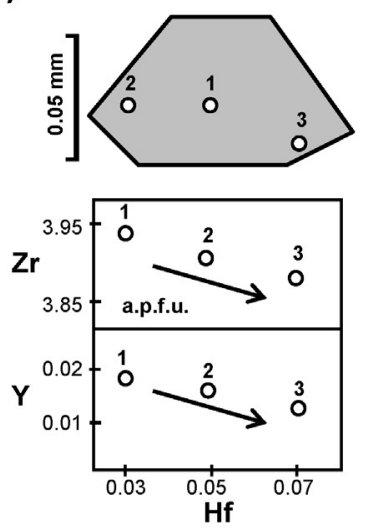

(g) Apatite [transmitted light]

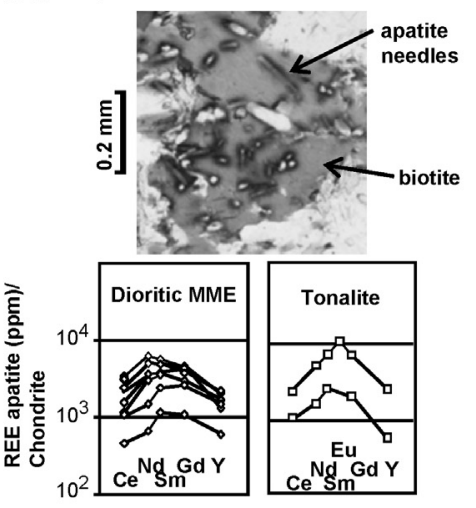

(i) Fe-Cu-Ni sulphides

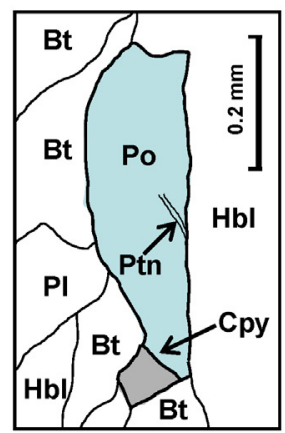

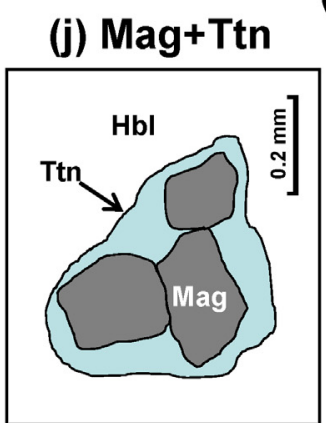

(k) Euhedral Ep+Ttn

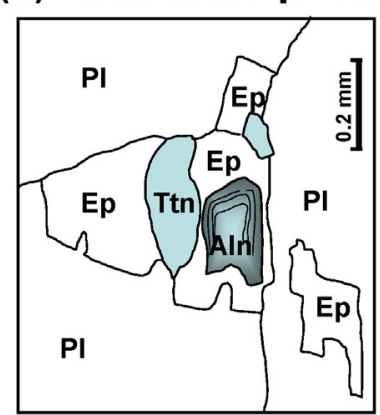

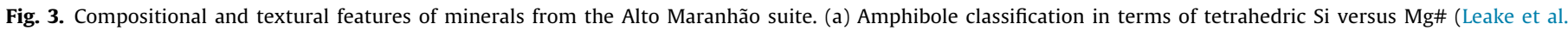

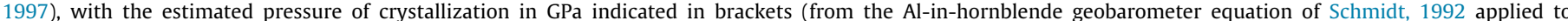

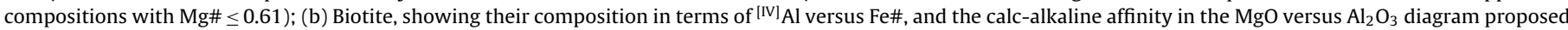

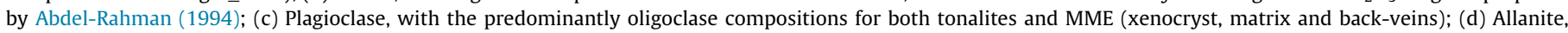


magmas in the $\mathrm{MgO}$ versus $\mathrm{Al}_{2} \mathrm{O}_{3}$ diagram of Abdel-Rahman (1994, Fig. $3 \mathrm{~b}$ ). Plagioclase in the tonalites forms euhedral to subeuhedral tabular and oscillatory zoned crystals, generally with $>2$ up to $8 \mathrm{~mm}$ long dimension. Oligoclase is the dominant plagioclase composition (from $\mathrm{An}_{27}$ in the core to $\mathrm{An}_{19}$ in the rim, Table 2), however locally with andesine core composition $\left(\mathrm{An}_{32}\right)$, and albite rims (Fig. 3c). Plagioclase in MME is fine grained $(<2 \mathrm{~mm})$ and anhedral, with the same range of compositions as tonalite hosts (Fig. 3c). Xenocrysts of plagioclase transferred from tonalites into MME can be distinguished by larger sizes, euhedral forms and oscillatory zoning, occurring either as individual crystals (Fig. 2d and g), or as clusters of crystals (Fig. 2e). Magnesiohornblende is included in plagioclase, thus indicating early crystallization.

Selected textural and compositional features of the accessory minerals are shown in Fig. 3d-k. The common occurrence of apatite, zircon and allanite within biotite, hornblende and/or plagioclase for both tonalites and MME indicates that these accessory minerals have crystallized early. Allanite is ubiquitous in both tonalites and MME (Table 1 and Fig. 2c). Its grain size matches the grain size of the host-rock, i.e. allanite is generally coarser in tonalites (up to $1 \mathrm{~mm}$, Fig. $3 \mathrm{~d}$ ) than in MME $(<0.2 \mathrm{~mm})$. This indicates that allanite nucleated as an independent phase in each of the magmas. Allanite is found commonly as euhedral zoned crystals, most of the grains displaying epidote coronas. Allanite crystals from the couple tonalite T15 and dioritic MME E9 show similar range of compositions in the space of the cationic REE versus Al diagram (Fig. 3d). Core compositions of three homogeneous fine crystals $(\leq 0.1 \mathrm{~mm})$ of the enclave and the core-to-rim composition of the coarser $(\sim 0.6 \mathrm{~mm})$ zoned crystal of the tonalite host plot at the same line of estimated Fe-oxidation state $\left(\mathrm{Fe}^{3+} / \mathrm{Fe}^{3+}+\mathrm{Fe}^{2+}\right.$ value of $\sim 0.3$, analyses of crystals a, b and c of sample E9, and analyses 1 to 6 of the crystal of the sample T15, Fig. 3d). The epidote corona of the crystal from the tonalite by contrast is $\mathrm{Fe}^{2+}$ - and REE-free (analysis 7, Fig. 3d). The chemical zonation observed from the core to the rim of the allanite crystal of the tonalite is marked by a slightly increase of Sm and Y, however retaining an overall decrease in REE total + Th. Using yttrium as a proxy for the behaviour of heavy REE (Rollinson, 1993), the Ce/Y decrease from core to rim of the zoned crystal indicates that allanite fractionation must have played a major role in changing light/heavy REE ratios in the different rocks of the suite. Zircon occurs as small $(<0.1 \mathrm{~mm})$ euhedral crystals included in magnesiohornblende, biotite and/or plagioclase, and yields commonly pleochroic haloes. Fig. 3f illustrates the chemical zonation of a zoned euhedral zircon included in a plagioclase from the tonalite of $\mathrm{T} 7$ work station. The zonation is characterized by decreasing $\mathrm{Zr} / \mathrm{Hf}$ and $\mathrm{Y} / \mathrm{Hf}$ ratios towards the rim of crystal. Apatite displays two basic textural types: (i) strongly acicular habit, characteristic of magma mingling textures (Fig. $3 \mathrm{~g}$ ), or (ii) short prism, typical of cumulus crystals. The microprobe analyses of thirteen apatite grains from the tonalite $\mathrm{T}$, plus from a tonalitic schlieren and from the dioritic MME E7 and E9 have revealed that the apatites from the granitoid hosts and enclaves have the same range of compositions, being classified as fluorapatites (with 1.65-3.22 wt.\% F), and containing relatively high contents of middle REE [e.g. 0.4-2.4 wt.\% of
$\left.\left(\mathrm{REE}_{2} \mathrm{O}_{3}+\mathrm{Y}_{2} \mathrm{O}_{3}\right)\right]$. Representative analyses are presented in Table 2 and chondrite-normalized REE patterns in Fig. $3 \mathrm{~g}$.

Opaque phases have variable distribution over the different lithologies and over the investigated sectors of the suite (Fig. 2c). Although a minutious investigation of these minerals is beyond the scope of this work, some preliminary notes could be addressed. The opaque phases are comprised by the Fe-Ti oxides ilmenite and magnetite and the sulphides chalcopyrite, pyrrotite, pyrite and pentlandite. Apparently magnetite and ilmenite are distributed over different sectors of the suite. Magnetite was found in the elongated pluton of the western sector of the suite in the sample T9 (Fig. 1c). They form isometric homogeneous crystals included in hornblende $(<0.25 \mathrm{~mm}$, average $0.1 \mathrm{~mm} \times 0.1 \mathrm{~mm})$, some of them surrounded by titanite coronas (Fig. $3 \mathrm{j}$ ). EDS analyses have identified small percentages of $\mathrm{TiO}_{2}$ and $\mathrm{Cr}_{2} \mathrm{O}_{3}$ (0.2-0.3\% for each oxide). The percentage of magnetite is considered important ( $\sim 50$ grains in the thin section). The main occurrences of ilmenite are found in the tonalites and enclaves of the southeastern sector (E1 and T3 samples). In these rocks it can be counted more than 150 crystals by thin section. The crystals occur mainly as inclusions in amphibole or occupying interstices between the silicate phases (greater crystals with $0.35 \mathrm{~mm}$, commonly $<0.18 \mathrm{~mm}$ ). In the latter situation symplectite subsolidus quartz + titanite formation are common at the expense of hornblende + ilmenite (Fig. $3 \mathrm{~h}$ ). Ilmenite also was characterized in the northern sector of the suite in samples of tonalites around T15 work station. It occurs in lower percentages (generally $<15$ grains by thin section), commonly as small inclusions in magnesiohornblende $(<0.1 \mathrm{~mm})$. Titanite coronas are common. Representative composition of ilmenite is presented in Table 2. They are poor in $\mathrm{Mg}$ and $\mathrm{Fe}^{3+}\left(\mathrm{X}_{\mathrm{HEM}}<0.005\right)$. The chemical composition of ilmenites from both situations are plotted in the triangular diagram of $\mathrm{MnO}-\mathrm{TiO}_{2}-\mathrm{Fe}_{2} \mathrm{O}_{3}$ (Fig. 3e) and compared with ilmenite compositions from ilmenite- and magnetite-series of granitic rocks of Japan (Ishihara, 1977; data from Shimizu, 1986). Ilmenite compositions of the Alto Maranhão suite are closer to ilmenites from ilmenite-series granites. Significative occurrences of the sulphide assemblage of chalcopyrite + pyrrotite \pm pentlandite are found in the northern sector of the suite, in the samples E4/E7/E9 and corresponding tonalite hosts $\mathrm{T} 7$ and $\mathrm{T} 15$. The same paragenesis is also important in the tonalite $\mathrm{T} 1$ (northwestern sector). In the enclave samples E7/E9 more than 250 grains are found in the same thin section, in T1 tonalite $\sim 50$ grains. In the enclaves E4, E7 and E9 the sulphide content corresponds to respectively 123,247 and $821 \mathrm{ppm}$ of copper in the chemical analysis of these samples. The sulphides are or inclusions in the silicates or interstitial phases (larger grains with $\sim 0.4 \mathrm{~mm}$, average $\leq 0.13 \mathrm{~mm}$ ). Textural example is presented in the Fig. 3i. The same paragenesis of Cpy + Po and/or with Py is also found in enclaves E1/E3/E5/E6 and associated tonalites hosts. In the E3 enclave Py + Cpy are abundant (>150 grains). The other accessory phases include epidote and titanite, which are found either as euhedral coarse crystals, frequently mantling allanite (epidote) and ilmenite and/or magnetite (titanite), or as small secondary crystals growing in cores of zoned plagioclase (epidote) and in cleavage planes of biotite and magnesiohornblende (titanite). The former textural types (example in Fig. 3h) are preliminarily interpreted

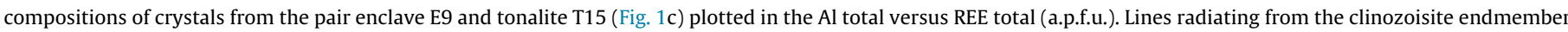

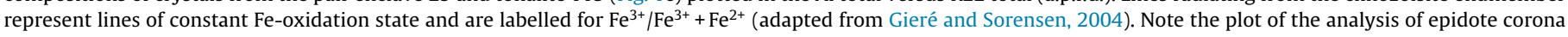

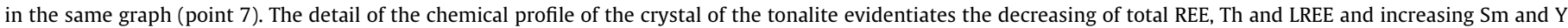

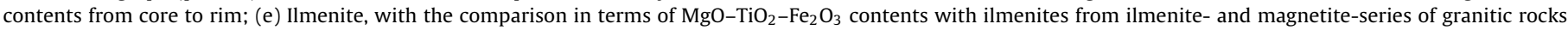

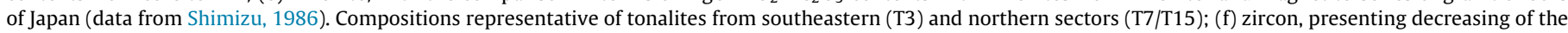

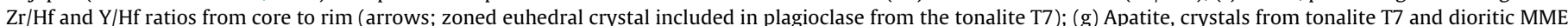

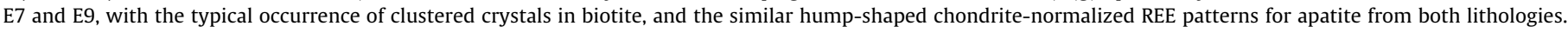

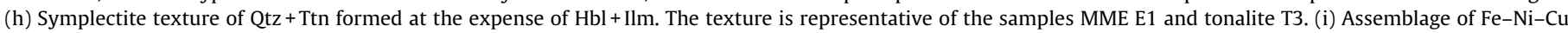

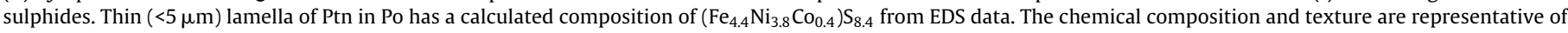

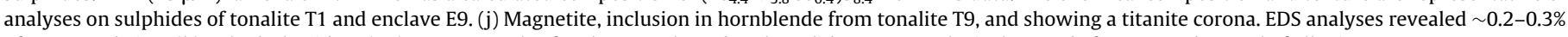
of $\mathrm{Cr}_{2} \mathrm{O}_{3}$ and $\mathrm{TiO}_{2}$. (k) Euhedral epidote (Ep) + Ttn. Crystals of Ep have nucleated at the solid state over plagioclase and after a zoned crystal of allanite. 

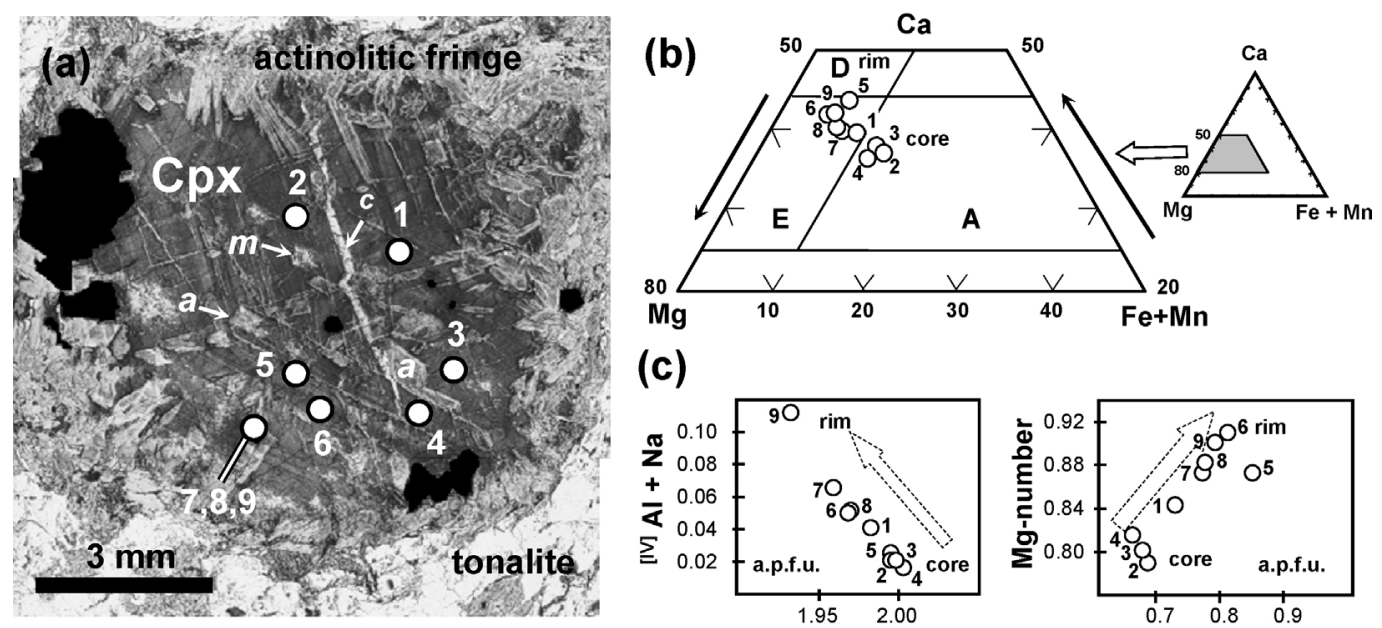

(c)
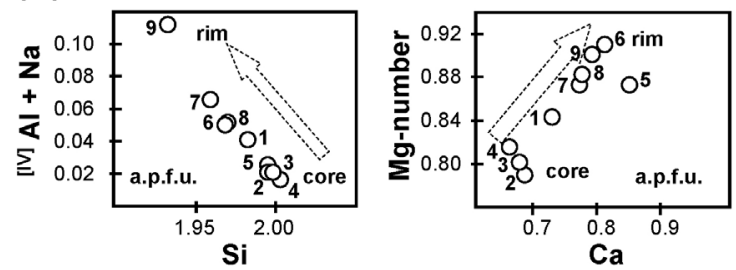

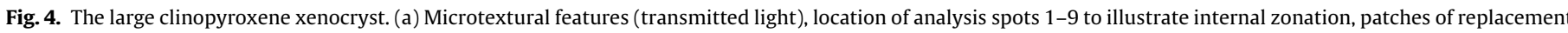

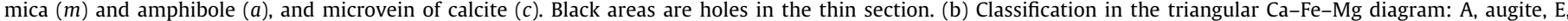

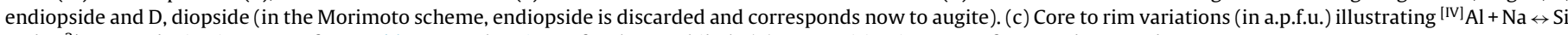
and $\mathrm{Fe}^{2+} \leftrightarrow$ Ca substitutions. Data from Table 2. See also Fig. 12 for the amphibole (a) composition in terms of $\mathrm{Mg}$ - and $\mathrm{Cr}-\mathrm{number}$.

as supra- to subsolidus minerals, according to the various studies concerning the occurrence of epidote in calc-alkaline magmas (Schmidt and Thompson, 1996; Schmidt and Poli, 2004), as also in the case of the titanites, the $\mathrm{U}-\mathrm{Pb}$ ages of titanites in tonalites of the region (see also Section 4.2. U-Pb geochronology). The fine grained textural types are considered retromorphic.

A rare occurrence of clinopyroxene was found in the form of a centimetric monocrystal enclave in a tonalite from the T7 sample site (location in Fig. 1c). The clinopyroxene is isolated from the felsic magma by a fringe of actinolitic amphibole, which prevented complete assimilation of the crystal and preserved its primary microscopic and compositional features (Fig. 4a). The clinopyroxene composition corresponds to chromian augite to magnesium-rich augite (Fig. $4 \mathrm{~b}$ and Table 3, nomenclature after Morimoto, 1988), with 0.6-1.1 wt.\% $\mathrm{Cr}_{2} \mathrm{O}_{3}$ and $\mathrm{Mg}$-number ranging from 0.79 to 0.91 . Internally, the clinopyroxene shows a complex chemical pattern, with an observed core-to-rim zonation due to the ${ }^{[\mathrm{IV}]} \mathrm{Al}+\mathrm{Na} \leftrightarrow 2 \mathrm{Si}$ substitution (i.e. jadeite molecule), and a positive covariation of Mg-number and Ca (Fig. 4c). Moreover, the clinopyroxene is altered internally into patches of secondary amphibole and black mica (phlogopitic mica with Mg-number $=0.74$, Table 3 ), as well as by calcite microveins that do not crosscut the tonalite host (Fig. 4a). Four analytical points in the amphibole of the internal replacements over the clinopyroxene (labelled $a$ in Fig. 4) have revealed composition equivalent of a calcic (tremolitic) amphibole, with low-aluminium (2.03-1.51 wt.\% $\mathrm{Al}_{2} \mathrm{O}_{3}$ ) and high Mg-number ( $\geq 0.78-0.84$ ) and $\mathrm{Cr}$ content (wt.\% $\mathrm{Cr}_{2} \mathrm{O}_{3}$ of 1.0-1.3, and an anomalous result of $6 \%$, data from Seixas, 2000).

\section{2. $U-P b$ geochronology}

Table 4 lists the results of new zircon U-Pb (ID-TIMS) dates for the Alto Maranhão suite (tonalite sample T3, Fig. 1c). The data are plotted in the Concordia diagram of Fig. 5. The analysed zircon grains are colourless to pink, short to long prismatic and bipyramidal. A discordia line drawn through all four multi-grain fractions (fractions A-D; Fig. 5) yields an upper intercept age of $2128 \pm 9.9 \mathrm{Ma}(\mathrm{MSWD}=2.9)$. This age is in agreement with the previous $2130 \pm 2$ Ma age obtained on zircon grains from the tonalite of sample locality T15 (sample N22 from Noce, 1995), which is located $\sim 35 \mathrm{~km}$ farther northwest. Taking into account these two $\mathrm{U}-\mathrm{Pb}$ zircon data, it is safe to assume the ca. $2130 \mathrm{Ma}$ age is the crystallization age of all investigated samples. In addition, it must be mentioned the $\mathrm{U}-\mathrm{Pb}$ age of $2124 \pm 2$ Ma of euhedral titanites from a hornblende-biotite tonalite placed between the T15 and T2/T5 work stations at the eastern sector of the suite (Fig. 1c, data from Noce, 1995 and Noce et al., 2000). The belonging of this tonalite - and other labelled miscellaneous biotite \pm hornblende tonalites with $T_{\mathrm{DM}}$ ages of $\sim 2.3-2.5 \mathrm{Ga}$ from the Fig. $1 \mathrm{c}$ ) to the Alto Maranhão suite as defined in this paper is matter of current research.

\subsection{Nd isotope composition}

Table 5 reports $\mathrm{Nd}$ isotope compositions of eight tonalite samples and four MME samples of the Alto Maranhão suite. The samples are distributed over a broad area to represent the entire suite (Fig. 1c). In the $\varepsilon_{\mathrm{Nd}}(t=2130 \mathrm{Ma}$ ) versus time diagram (Fig. 6), tonalites and dioritic MME yield similar ranges of Nd isotope compositions. $T_{\mathrm{DM}}$ model ages range from 2.3 to $2.4 \mathrm{Ga}$ and $\varepsilon_{\mathrm{Nd}}(t)$ values from -1.0 to +0.9 . Fig. 6 also shows Nd isotopic composition of rocks representative of surrounding older (presumably Archaean) crust, one sample of tholeiitic metabasaltic amphibolite

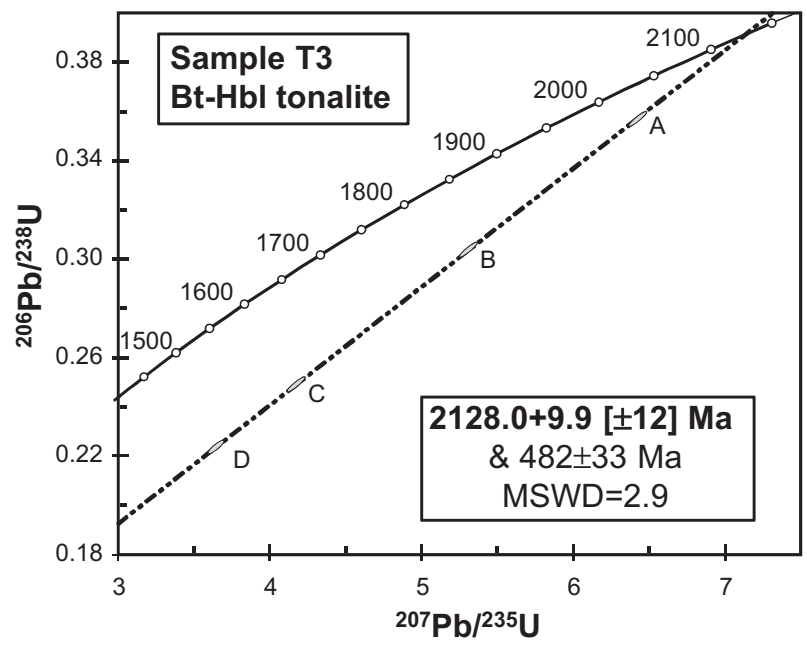

Fig. 5. Concordia diagram showing $\mathrm{U}-\mathrm{Pb}$ isotopic data for zircon fractions from sample T3. Error ellipses are at $2 \kappa$ level. 
Table 3

Clinopyroxene xenocrystal analyses and associated black mica replacements, Alto Maranhão suite.

\begin{tabular}{|c|c|c|c|c|c|c|c|c|c|c|c|}
\hline \multirow{2}{*}{$\begin{array}{l}\text { Cpx } \\
\text { Analysis }\end{array}$} & \multicolumn{3}{|l|}{ Core } & \multicolumn{4}{|c|}{ Mantle } & \multicolumn{2}{|l|}{ Rim } & \multicolumn{2}{|l|}{ Black mica } \\
\hline & 1 & 2 & 3 & 4 & 5 & 6 & 7 & 8 & 9 & Ox. & \\
\hline $\mathrm{SiO}_{2}$ & 54.02 & 53.84 & 54.53 & 54.55 & 54.54 & 53.38 & 53.94 & 54.45 & 53.02 & $\mathrm{SiO}_{2}$ & 38.48 \\
\hline $\mathrm{TiO}_{2}$ & 0.16 & 0.07 & 0.11 & 0.17 & 0.11 & 0.15 & 0.18 & 0.18 & 0.28 & $\mathrm{TiO}_{2}$ & 0.67 \\
\hline $\mathrm{Al}_{2} \mathrm{O}_{3}$ & 1.77 & 1.27 & 1.91 & 1.71 & 0.91 & 1.38 & 1.48 & 1.49 & 2.62 & $\mathrm{Al}_{2} \mathrm{O}_{3}$ & 15.39 \\
\hline $\mathrm{FeO}_{\mathrm{t}}$ & 5.64 & 7.90 & 7.35 & 6.97 & 4.32 & 3.21 & 4.84 & 4.42 & 3.58 & $\mathrm{FeO}_{\mathrm{t}}$ & 11.19 \\
\hline $\mathrm{Cr}_{2} \mathrm{O}_{3}$ & 0.88 & 1.07 & 0.82 & 0.69 & 0.67 & 0.63 & 0.64 & 0.56 & 0.81 & $\mathrm{Cr}_{2} \mathrm{O}_{3}$ & 1.64 \\
\hline $\mathrm{MnO}$ & 0.24 & 0.32 & 0.30 & 0.36 & 0.33 & 0.12 & 0.19 & 0.10 & 0.09 & $\mathrm{MnO}$ & 0.16 \\
\hline $\mathrm{MgO}$ & 17.19 & 16.61 & 16.70 & 17.21 & 16.60 & 18.59 & 18.77 & 18.63 & 18.13 & $\mathrm{MgO}$ & 17.87 \\
\hline $\mathrm{CaO}$ & 18.57 & 17.31 & 17.48 & 16.92 & 21.75 & 20.35 & 19.70 & 19.83 & 20.32 & $\mathrm{CaO}$ & 0.00 \\
\hline $\mathrm{Na}_{2} \mathrm{O}$ & 0.32 & 0.24 & 0.25 & 0.23 & 0.31 & 0.26 & 0.35 & 0.33 & 0.64 & $\mathrm{Na}_{2} \mathrm{O}$ & 0.05 \\
\hline $\mathrm{K}_{2} \mathrm{O}$ & 0.13 & 0.09 & 0.14 & 0.12 & 0.04 & 0.01 & 0.02 & 0.00 & 0.00 & $\mathrm{~K}_{2} \mathrm{O}$ & 8.80 \\
\hline $\mathrm{F}$ & 0.17 & 0.10 & 0.00 & 0.00 & 0.04 & 0.03 & 0.02 & 0.13 & 0.05 & $\mathrm{~F}$ & 0.54 \\
\hline $\mathrm{Cl}$ & 0.00 & 0.00 & 0.00 & 0.00 & 0.00 & 0.00 & 0.00 & 0.00 & 0.01 & $\mathrm{Cl}$ & 0.00 \\
\hline$-\mathrm{O}=\mathrm{F}, \mathrm{Cl}$ & 0.07 & 0.04 & 0.00 & 0.00 & 0.02 & 0.01 & 0.01 & 0.05 & 0.02 & $-\mathrm{O}=\mathrm{F}, \mathrm{Cl}$ & 0.23 \\
\hline Total & 98.83 & 98.66 & 99.58 & 98.94 & 99.56 & 98.05 & 100.10 & 99.94 & 99.46 & Total & 94.57 \\
\hline $\mathrm{Si}$ & 1.982 & 1.995 & 1.996 & 2.003 & 1.996 & 1.968 & 1.959 & 1.970 & 1.932 & $\mathrm{Si}$ & 5.685 \\
\hline $\mathrm{Al}^{\mathrm{IV}}$ & 0.018 & 0.005 & 0.004 & 0.000 & 0.004 & 0.032 & 0.041 & 0.030 & 0.068 & $\mathrm{Al}^{\mathrm{IV}}$ & 2.315 \\
\hline $\mathrm{Al}^{\mathrm{VI}}$ & 0.058 & 0.050 & 0.078 & 0.074 & 0.035 & 0.028 & 0.022 & 0.034 & 0.045 & $\mathrm{Al}^{\mathrm{VI}}$ & 0.364 \\
\hline $\mathrm{Ti}$ & 0.004 & 0.002 & 0.003 & 0.005 & 0.003 & 0.004 & 0.005 & 0.005 & 0.008 & $\mathrm{Ti}$ & 0.074 \\
\hline $\mathrm{Cr}$ & 0.025 & 0.031 & 0.024 & 0.020 & 0.019 & 0.018 & 0.018 & 0.016 & 0.023 & $\mathrm{Cr}$ & 0.190 \\
\hline $\mathrm{Fe}_{\mathrm{t}}$ & 0.173 & 0.245 & 0.225 & 0.214 & 0.132 & 0.099 & 0.147 & 0.134 & 0.109 & $\mathrm{Fe}_{\mathrm{t}}$ & 1.383 \\
\hline $\mathrm{Mn}$ & 0.007 & 0.010 & 0.009 & 0.011 & 0.010 & 0.004 & 0.006 & 0.003 & 0.003 & $\mathrm{Mn}$ & 0.020 \\
\hline $\mathrm{Mg}$ & 0.940 & 0.917 & 0.911 & 0.942 & 0.905 & 1.022 & 1.016 & 1.005 & 0.985 & $\mathrm{Mg}$ & 3.936 \\
\hline $\mathrm{Ca}$ & 0.730 & 0.687 & 0.685 & 0.665 & 0.853 & 0.804 & 0.767 & 0.769 & 0.793 & Tot.Y & 5.969 \\
\hline $\mathrm{Na}$ & 0.022 & 0.017 & 0.018 & 0.017 & 0.022 & 0.018 & 0.025 & 0.023 & 0.045 & $\mathrm{Ca}$ & 0.000 \\
\hline K & 0.006 & 0.004 & 0.007 & 0.006 & 0.002 & 0.001 & 0.001 & 0.000 & 0.000 & $\mathrm{Na}$ & 0.015 \\
\hline Tot. Cat. & 3.97 & 3.96 & 3.96 & 3.96 & 3.98 & 4.00 & 4.01 & 3.99 & 4.01 & K & 1.658 \\
\hline $\mathrm{F}$ & 0.020 & 0.012 & 0.000 & 0.000 & 0.005 & 0.004 & 0.002 & 0.015 & 0.005 & Tot.X & 1.673 \\
\hline $\mathrm{Cl}$ & 0.000 & 0.000 & 0.000 & 0.000 & 0.000 & 0.000 & 0.000 & 0.000 & 0.001 & Tot. Cat. & 15.64 \\
\hline En & 50.80 & 49.34 & 49.77 & 51.41 & 47.65 & 52.98 & 52.49 & 52.61 & 52.11 & $\mathrm{~F}$ & 0.254 \\
\hline Wo & 39.44 & 36.95 & 37.43 & 36.31 & 44.87 & 41.69 & 39.61 & 40.22 & 41.97 & $\mathrm{Cl}$ & 0.001 \\
\hline Fs & 9.76 & 13.71 & 12.80 & 12.29 & 7.49 & 5.33 & 7.90 & 7.16 & 5.92 & Mg-no. & 0.74 \\
\hline Mg-no. & 0.84 & 0.79 & 0.80 & 0.82 & 0.87 & 0.91 & 0.87 & 0.88 & 0.90 & Calculated as in Table 1. & \\
\hline Classif. & A-E & A & A & A & A-D & $\mathrm{E}$ & $\mathrm{E}$ & $\mathrm{E}$ & $\mathrm{E}$ & & \\
\hline
\end{tabular}

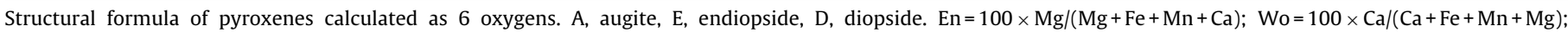
$\mathrm{Fs}=100 \times(\mathrm{Fe}+\mathrm{Mn}) /(\mathrm{Fe}+\mathrm{Mn}+\mathrm{Ca}+\mathrm{Mg})$.

and three samples of intermediate quartz diorite to felsic trondhjemite orthogneisses; as also the Nd isotopic composition of the 2350 Ma Lagoa Dourada suite, these latter rocks representing juvenile high-aluminium TTG crust issued from melting of tholeiitic source rocks in the beginning of the Paleoproterozoic in the Mineiro Belt (data from Seixas et al., 2012, location of samples in Fig. 1c). As far as Nd isotopic compositions are concerned, all the presumably Archaean rocks differ markedly to the Alto Maranhão suite by showing more negative $\varepsilon_{\mathrm{Nd}}(t=2130 \mathrm{Ma})$ values (respectively -2.1 for amphibolite, and -10 to -13.6 for orthogneisses). Thus, it can be postulated that both tonalites and dioritic MME of the Alto Maranhão suite were issued from a similar juvenile source, with no important signs of assimilation of these older crustal rocks. By contrast, there is a gently superposition between the $\varepsilon \mathrm{Nd}$ of the Alto Maranhão suite rocks $(-1.0$ to +0.9$)$ with the line of evolution of the $\varepsilon \mathrm{Nd}$ isotopic composition of the rocks of the Lagoa Dourada suite at $t=2130 \mathrm{Ma}(-0.3$ to -1.8$)$. This aspect is further explorated in Sections 5.1 and 5.3.

\subsection{Whole rock geochemistry}

The chemical compositions of tonalites and dioritic MME of the Alto Maranhão suite are listed in Table 6. Classification diagrams are presented in Fig. 7. In the AFM diagram (Fig. 7a) the tonalites and MME are calc-alkaline rocks. Most of the tonalitic rocks sampled for this study have $\geq 10 \%$ normative quartz and plot in the tonalite-granodiorite field of the Ab-An-Or normative diagram (Fig. 7b; samples T1-T4 with $8 \% \leq$ normative quartz $<10 \%$ were also included). The cluster of points in the granodiorite field in this diagram reflects mainly $\mathrm{K}_{2} \mathrm{O}$ contained within modal biotite and amphibole and not $\mathrm{K}$-feldspar. In the cationic $\mathrm{Na}-\mathrm{K}-\mathrm{Ca}$ triangular diagram, the tonalites plot closer to the tonalitic-trondhjemitic trend (Fig. 7c). The position of the granitoids of the Alto Maranhão suite aside of the calc-alkaline trend in Fig. 7c, which characterizes the sanukitoid suites, is due to its lack of monzodioritic and K-feldspar porphyritic granodioritic terms. The tonalites are intermediate to slightly acid (59.7 to $66.4 \mathrm{wt} . \% \mathrm{SiO}_{2}$ ), dominantly medium- $\mathrm{K}\left(\mathrm{K}_{2} \mathrm{O} / \mathrm{Na}_{2} \mathrm{O} \leq 0.7\right.$, Fig. $7 \mathrm{~d}$ and e) and metaluminous (Fig. 7f). The dioritic MME are basic to intermediate (47.7-54.6 wt.\% $\mathrm{SiO}_{2}$ ), medium- and high-K (Fig. 7d and e) and metaluminous (Fig. 7f). $\mathrm{K}_{2} \mathrm{O}$ contents and $\mathrm{K}_{2} \mathrm{O} / \mathrm{Na}_{2} \mathrm{O}$ weight ratios are the highest in the MME $\left(0.97 \leq \mathrm{K}_{2} \mathrm{O} \leq 3.6 \mathrm{wt} . \%\right.$ and $\left.0.2 \leq \mathrm{K}_{2} \mathrm{O} / \mathrm{Na}_{2} \mathrm{O} \leq 1.2\right)$ that have the lowest contents of $\mathrm{SiO}_{2}$ (Fig. $7 \mathrm{~d}$ and e). Last, $\mathrm{A} / \mathrm{CNK}$ values $\left[\mathrm{A} / \mathrm{CNK}=\right.$ molar $\left.\mathrm{Al}_{2} \mathrm{O}_{3} /\left(\mathrm{CaO}+\mathrm{Na}_{2} \mathrm{O}+\mathrm{K}_{2} \mathrm{O}\right)\right]$ are the highest in the most siliceous compositions in both tonalites and MME (Fig. 7f).

Harker-like diagrams for major, compatible, LIL and HFS elements are shown in Fig. 8. Tonalites display a well-defined negative correlation between silica and $\mathrm{CaO}, \mathrm{MgO}, \mathrm{Fe}_{2} \mathrm{O}_{3 \mathrm{t}}, \mathrm{P}_{2} \mathrm{O}_{5}$ and $\mathrm{TiO}_{2}$ oxides, and with $\mathrm{Cr}, \mathrm{V}, \mathrm{Sr}, \mathrm{Ba}, \mathrm{Th}, \mathrm{Nb}, \mathrm{Zr}$ and $\mathrm{Y}$ trace elements. On the contrary, silica is positively correlated with $\mathrm{Na}_{2} \mathrm{O}$ and $\left[\left(\mathrm{Na}_{2} \mathrm{O}+\mathrm{K}_{2} \mathrm{O}\right) / \mathrm{CaO}\right] . \mathrm{Al}_{2} \mathrm{O}_{3}, \mathrm{~K}_{2} \mathrm{O}$ (Fig. $7 \mathrm{~d}$ ), $\mathrm{Rb}$ and $\mathrm{U}$ do not show well defined correlations with silica. MME diorites display the same correlations as tonalites, e.g., negative correlation of silica with $\mathrm{MgO}$, $\mathrm{Fe}_{2} \mathrm{O}_{3 \mathrm{t}}, \mathrm{P}_{2} \mathrm{O}_{5}$ and $\mathrm{TiO}_{2}$ oxides and $\mathrm{Cr}, \mathrm{V}, \mathrm{Ba}, \mathrm{Th}, \mathrm{Nb}, \mathrm{Zr}$ and $\mathrm{Y}$ trace elements, and positive correlation with $\mathrm{Na}_{2} \mathrm{O}$. In contrast to the tonalites, they yield a well defined negative correlation of silica with $\mathrm{K}_{2} \mathrm{O}$ (Fig. 7c), $\mathrm{Rb}$ and $\mathrm{U}$, while correlations with silica of $\mathrm{CaO}$, $\mathrm{Al}_{2} \mathrm{O}_{3}$ and $\mathrm{Sr}$ are less well defined. 


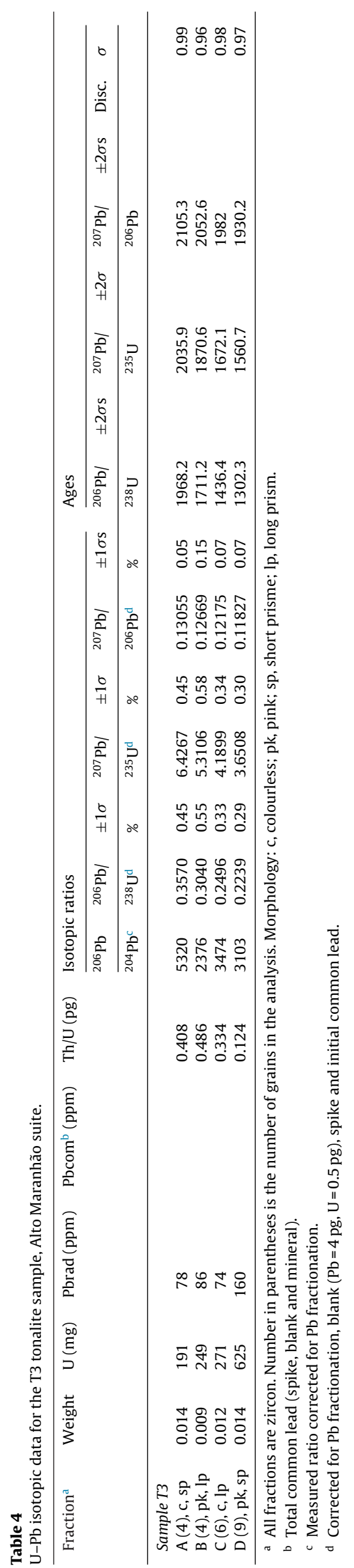

Chondrite-normalized REE patterns, correlations of $\mathrm{SiO}_{2}$ with $\mathrm{Ce}, \mathrm{Yb}$, and correlations of $\mathrm{La}_{\mathrm{N}} / \mathrm{Yb}_{\mathrm{N}}$ and $\mathrm{Eu} / \mathrm{Eu}^{*}$ ratios with EREE (ppm) are presented in Fig. 9. As a whole, tonalites show REE patterns characterized by: (i) low heavy REE contents (Yb<1.8 ppm, Fig. 9d); (ii) highly fractionated light/heavy REE ratios $\left(\mathrm{La}_{\mathrm{N}} / \mathrm{Yb}_{\mathrm{N}} \geq 12\right.$ up to 80 , Fig. 9a and e); (iii) negative correlations of $\mathrm{SiO}_{2}$ with light (Ce) and heavy (Yb) REE (Fig. 9c and d), and a positive correlation between $(\mathrm{La} / \mathrm{Yb})_{\mathrm{N}}$ ratios and $\Sigma \mathrm{REE}(\mathrm{ppm})$ (Fig. 9e); and (iv) slightly negative to clearly positive europium anomalies $\left(0.75 \leq \mathrm{Eu} / \mathrm{Eu}^{*} \leq 1.41\right.$, Fig. 9 f). Tonalites with neutral or positive $\mathrm{Eu} / \mathrm{Eu}^{*}$ ratios correspond to samples with higher silica and lower $\Sigma$ REE (ppm) (Fig. 9e and f). Chondrite-normalized REE patterns, total REE contents and $(\mathrm{La} / \mathrm{Yb})_{\mathrm{N}}$ ratios of MME overlap with those of the tonalites (Fig. 9a-f), except for the more pronounced negative $\mathrm{Eu} / \mathrm{Eu}^{*}$ anomaly for MME samples $\mathrm{E} 7$ and $\mathrm{E} 9$ $\left(\mathrm{Eu} / \mathrm{Eu}^{*}=0.62\right.$ and 0.36 , respectively; Fig. 9f). Indeed, these two samples have the highest REE contents ( 740 and 1240 ppm, respectively) compared to both tonalites and the other MME. In primitive mantle-normalized diagrams (Fig. 10), tonalites and MME exhibit the following common characteristics: (i) negative slopes from LILE to HFSE; (ii) negative spikes of $\mathrm{Nb}-\mathrm{Ta}$, $\mathrm{P}$ and Ti relative to their neighbouring elements; and (iii) highly fractionated light-toheavy REE. Moreover, Ba is always enriched relative to $\mathrm{Rb}$ (except sample E9 due to its highest Rb content); Th may be either enriched or depleted relative to $\mathrm{Ba}$ and $\mathrm{K}$; as well as $\mathrm{Sr}$ relatively to light REE Ce and Nd.

\section{Discussion}

In this section, field, mineralogical, geochemical and isotopic data are discussed in terms of source rocks, parental magmas, magmatic evolution and petrotectonic setting. Table 7 gives a summary of selected petrochemical parameters of tonalites and dioritic MME of the Alto Maranhão suite.

\subsection{Source rocks}

Tonalites and dioritic MME of the Alto Maranhão suite both have high Mg-numbers [Mg-number $=100 \times \mathrm{mol}$ $\left.\mathrm{MgO} /\left(\mathrm{MgO}+\mathrm{FeO}_{\mathrm{t}}\right) \geq 46\right]$ and $\mathrm{Cr}$ contents $(\mathrm{Cr} \geq 55 \mathrm{ppm}$, Tables 6 and 7 ). These parameters preclude mafic infracrustal (e.g., basaltic) precursor source materials (Evans and Hanson, 1997; Rapp, 1997). In addition, the suite has high contents in LILE (Ba, Sr), light REE and highly incompatible HFSE (Th and U). As all of these elements (with the exception of $U$ for tonalites) show negative correlation with silica (Figs. 8 and 9c), enrichment in incompatible trace elements was not an artefact of the degree of fractionation of the most siliceous members of the suite, but must have been related to an originally enriched source (Martin et al., 2010). These geochemical attributes coupled with the arc-like signatures (Kelemen et al., 2004) of the primitive mantle-normalized diagrams (Fig. 10) point towards an arc-related origin for the suite. Furthermore, the similar near-chondritic $\varepsilon_{\mathrm{Nd}}(t)$ values for both tonalites and dioritic MME attest to the relatively juvenile origin of the magmas. Thus, the most probable source for the Alto Maranhão suite was a metasomatised mantle wedge above a Paleoproterozoic subduction zone. In fact, the apparent significantly older $T_{\mathrm{DM}}$ ages (between 2.3 and $2.4 \mathrm{Ga}$ ) than the crystallization age of the suite - as established by the zircon U-Pb data (i.e., 2.13 Ga) already presented, must be seen with caution. Pimentel and Charnley (1991) have demonstrated that granitoid suites that fractionate allanite could increase the $\mathrm{Sm} / \mathrm{Nd}$ ratios and hence the $T_{\mathrm{DM}}$ values with progressive differentiation. The microprobe data of the zoned allanite from the tonalite T15 sample (Fig. 3d) show a slightly increase of $\mathrm{Sm}$ from the core to the rim of the crystal, however 
Table 5

$\mathrm{Nd}$ isotope composition of tonalites and dioritic MME, Alto Maranhão suite.

\begin{tabular}{|c|c|c|c|c|c|c|c|c|c|}
\hline Sample & Age $(\mathrm{Ga})^{\mathrm{a}}$ & $\mathrm{Sm}(\mathrm{ppm})^{\mathrm{b}}$ & $\mathrm{Nd}(\mathrm{ppm})^{\mathrm{b}}$ & ${ }^{147} \mathrm{Sm} /{ }^{144} \mathrm{Nd}^{\mathrm{b}}$ & ${ }^{143} \mathrm{Nd} /{ }^{144} \mathrm{Nd}^{\mathrm{c}}$ & $2 \sigma$ & $\varepsilon_{\mathrm{Nd}}(0)$ & $\varepsilon_{\mathrm{Nd}}(t)^{\mathrm{d}}$ & $T_{\mathrm{DM}}(\mathrm{Ga})^{\mathrm{e}}$ \\
\hline \multicolumn{10}{|c|}{ Tonalites } \\
\hline $\mathrm{T} 1$ & 2.130 & 9.00 & 51.0 & 0.1071 & 0.511376 & 13 & -24.6 & -0.1 & 2.4 \\
\hline $\mathrm{T} 2$ & 2.130 & 14.0 & 104 & 0.0812 & 0.511065 & 8 & -30.7 & +0.9 & 2.3 \\
\hline T3 & 2.130 & 10.7 & 73.2 & 0.0886 & 0.511070 & 7 & -30.6 & -1.0 & 2.4 \\
\hline $\mathrm{T} 4$ & 2.130 & 9.30 & 56.7 & 0.0990 & 0.511284 & 11 & -26.4 & +0.2 & 2.3 \\
\hline T5 & 2.130 & 8.59 & 48.8 & 0.1064 & 0.511354 & 9 & -25.0 & -0.4 & 2.4 \\
\hline $\mathrm{T} 7$ & 2.130 & 7.43 & 45.1 & 0.0995 & 0.511279 & 9 & -26.5 & +0.1 & 2.3 \\
\hline $\mathrm{T} 12$ & 2.130 & 4.56 & 24.9 & 0.1108 & 0.511394 & 18 & -24.3 & -0.8 & 2.4 \\
\hline T13 & 2.130 & 5.35 & 32.3 & 0.0999 & 0.511302 & 16 & -26.1 & +0.3 & 2.3 \\
\hline \multicolumn{10}{|c|}{ Dioritic MME } \\
\hline E1 & 2.130 & 6.49 & 34.8 & 0.1126 & 0.511427 & 5 & -23.6 & -0.6 & 2.4 \\
\hline E5 & 2130 & 12.9 & 88.2 & 0.0883 & 0.511150 & 10 & -29 & +0.6 & 2.3 \\
\hline E7 & 2.130 & 32.3 & 176 & 0.1107 & 0.511438 & 9 & -23.4 & +0.1 & 2.4 \\
\hline E9 & 2.130 & 40.8 & 242 & 0.1018 & 0.511319 & 8 & -25.7 & +0.2 & 2.3 \\
\hline
\end{tabular}

a Crystallization age based on sample tonalite T3, this study.

b $\mathrm{Sm}$ and Nd concentrations and ${ }^{147} \mathrm{Sm} /{ }^{144} \mathrm{Nd}$ ratios accurate to within $0.5 \%$.

c ${ }^{143} \mathrm{Nd} /{ }^{144} \mathrm{Nd}$ normalized to ${ }^{146} \mathrm{Nd} /{ }^{144} \mathrm{Nd}=0.7219$.

d $\varepsilon_{\mathrm{Nd}}(t)$ values from crystallization age and chondritic ratios of ${ }^{143} \mathrm{Nd} /{ }^{144} \mathrm{Nd}=0.512638$ and ${ }^{147} \mathrm{Sm} /{ }^{144} \mathrm{Nd}=0.1966$. Maximum error is $0.5 \varepsilon_{\mathrm{Nd}}$ units.

e Nd model ages calculated using depleted mantle model of DePaolo (1981).

retaining an overall decrease in REE total + Th. Although these data are not conclusive, the effect of allanite fractionation cannot be discarded in increasing the calculated $T_{\mathrm{DM}}$ age of some members of the Alto Maranhão suite. Indeed, the calculated $T_{\mathrm{DM}}$ ages of 2.3-2.4Ga of the tonalites and MME have the only meaning to indicate both rocks have maximum age of extraction of the magma from the ultimate mantle source during the Paleoproterozoic. The most important information comes from the $\varepsilon \mathrm{Nd}$ values and the geochemistry of the rocks that indicate the most probable source was the metasomatised mantle.

The geochemistry and petrography of the Alto Maranhão suite are discussed below in an effort to constrain the origin of the mantle wedge metasomatism, i.e. slab-derived dehydration fluids versus slab-derived melts. Fluids derived from slab dehydration may enrich the mantle wedge in LILE $(\mathrm{K}, \mathrm{Rb}, \mathrm{Sr}, \mathrm{Ba})$, while slab-derived melts can introduce not only LILE, but also light REE and highly incompatible HFSE (Th), but are depleted in Ta-Nb and heavy REE (Martin et al., 2010; Rapp et al., 2010). In the first case, the derivative magmas form the calc-alkaline basalt-andesite-dacite-riolite (BADR) volcanic suites (and plutonic counterparts), whereas, in the latter case, melting of the metasomatised mantle wedge may produce primary magmas of high-Mg andesitic composition (Kelemen et al., 2004), with the corresponding plutonic counterparts represented by high-Mg (sanukitoid) dioritic to granodioritic granitoid suites. Martin et al. (2010) suggested the (Nb/Y) versus
(La/Yb) diagram to discriminate between these two possibilities (Fig. 11a). In this diagram, the Alto Maranhão suite is akin to igneous suites derived from a mantle source metasomatised by slab-derived melts. The geochemistry of these rocks is envisaged to have occurred as a consequence of the interaction of slab-derived melts with the mantle wedge. The whole process implies: (i) a subduction zone; (ii) downgoing slab material; (iii) melting of the tholeiitic mafic slab left behind garnet amphibolites to amphibole eclogitic residues; (iv) reaction between the slab-derived melts with the overlying mantle; and (v) melting of the metasomatised mantle. The parental magmas of the high-Mg granitoid suites are envisaged to have been generated in the steps (iv) or (v). Furthermore, after an extensive compilation of the geochemistry of the sanukitoid suites, Martin et al. (2010) have noted two main groups based in the Ti-contents of the rocks. The diagram of Fig. 11b shows that the Alto Maranhão suite can be ascribed to the Low-Ti group, for which it is proposed the generation as a consequence of the reaction and/or assimilation of slab-derived melts with the mantle wedge, i.e., the stage (iv) above (the one-stage process of Martin et al., 2010). Evidence of previous tholeiitic source, probably slabderived melts in the petrotectonic history of the Mineiro Belt is found in the recently discovered $2.35 \mathrm{Ga}$ high-aluminium Lagoa Dourada TTG suite (Seixas et al., 2012, see Fig. 1c for geographical location). The gently superposition of the $\varepsilon \mathrm{Nd}$ of this suite for the time $t=2130 \mathrm{Ma}$ (Fig. 6) with the Nd composition of the Alto
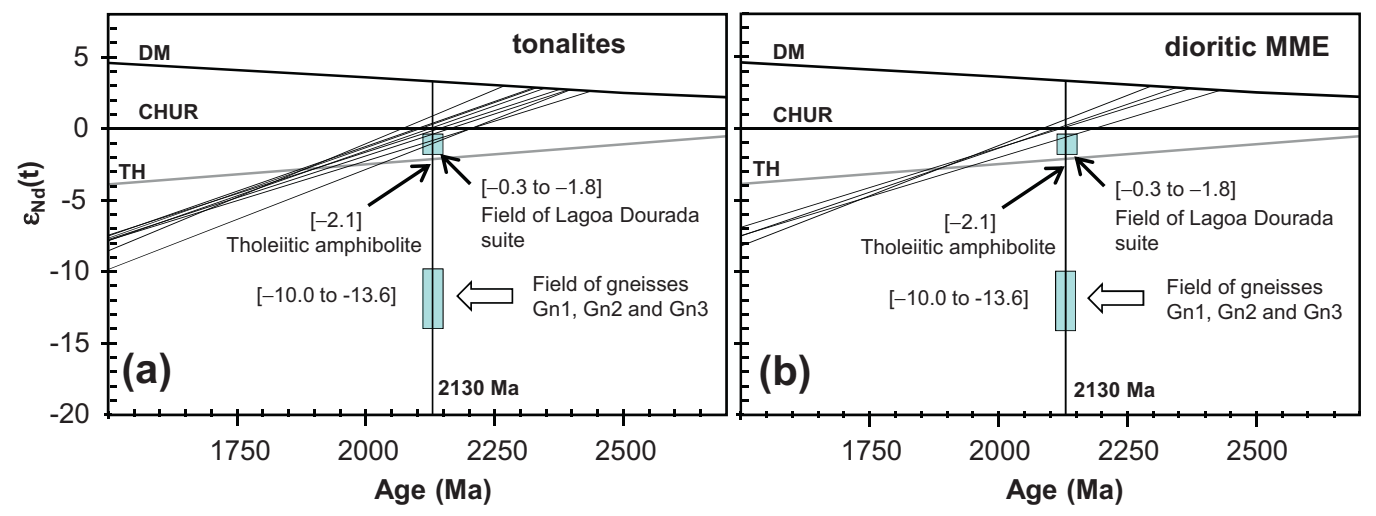

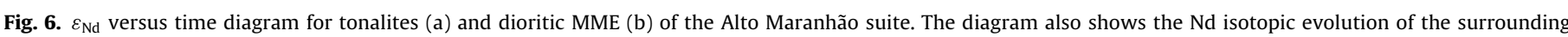

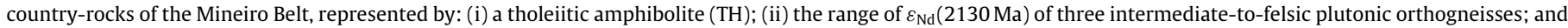

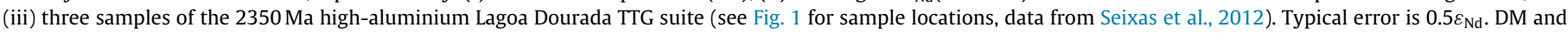
CHUR denote depleted mantle (after DePaolo, 1981) and chondritic uniform reservoir, respectively. 
Table 6

Major and trace element data of the investigated tonalites and dioritic MME, Alto Maranhão suite.

\begin{tabular}{|c|c|c|c|c|c|c|c|c|c|c|c|c|c|c|c|c|}
\hline \multirow[t]{2}{*}{ Sample } & \multicolumn{16}{|l|}{ Tonalites } \\
\hline & T1 & $\mathrm{T} 2$ & T3 & $\mathrm{T} 4$ & T5 & T6 & T7 & T8 & T9 & T10 & T11 & $\mathrm{T} 12$ & T13 & T14 & T15 & Range \\
\hline $\mathrm{SiO}_{2}$ & 59.65 & 60.10 & 60.59 & 60.78 & 61.58 & 61.81 & 62.52 & 62.75 & 62.92 & 63.07 & 63.26 & 63.56 & 63.71 & 63.75 & 66.39 & $59.7-66.4$ \\
\hline $\mathrm{TiO}_{2}$ & 0.68 & 0.70 & 0.70 & 0.73 & 0.64 & 0.78 & 0.59 & 0.69 & 0.63 & 0.68 & 0.63 & 0.66 & 0.70 & 0.56 & 0.47 & $0.47-0.78$ \\
\hline $\mathrm{Al}_{2} \mathrm{O}_{3}$ & 15.68 & 15.31 & 15.34 & 15.29 & 15.30 & 16.02 & 14.67 & 16.19 & 15.96 & 16.30 & 15.38 & 15.52 & 15.86 & 15.25 & 14.65 & $14.7-16.3$ \\
\hline $\mathrm{Fe}_{2} \mathrm{O}_{3 \mathrm{t}}$ & 6.05 & 6.20 & 5.84 & 5.88 & 5.37 & 5.48 & 5.43 & 5.18 & 5.69 & 4.86 & 5.67 & 5.30 & 4.77 & 5.05 & 4.13 & $4.1-6.2$ \\
\hline $\mathrm{MnO}$ & 0.09 & 0.09 & 0.08 & 0.09 & 0.07 & 0.02 & 0.08 & 0.08 & 0.09 & 0.06 & 0.09 & 0.02 & 0.02 & 0.08 & 0.06 & $0.02-0.09$ \\
\hline $\mathrm{MgO}$ & 4.57 & 4.16 & 3.97 & 4.08 & 3.73 & 2.82 & 3.74 & 2.84 & 2.47 & 2.48 & 2.58 & 3.56 & 2.97 & 3.21 & 2.60 & $2.5-4.6$ \\
\hline $\mathrm{CaO}$ & 5.12 & 5.28 & 5.13 & 5.13 & 4.62 & 4.60 & 4.06 & 4.09 & 4.90 & 4.08 & 4.55 & 4.60 & 4.24 & 3.52 & 3.38 & $3.4-5.3$ \\
\hline $\mathrm{Na}_{2} \mathrm{O}$ & 4.63 & 4.08 & 4.14 & 4.01 & 4.35 & 4.54 & 4.12 & 4.54 & 4.48 & 4.77 & 4.33 & 4.26 & 4.62 & 4.52 & 4.51 & $4.0-4.8$ \\
\hline $\mathrm{K}_{2} \mathrm{O}$ & 1.66 & 2.39 & 2.63 & 2.71 & 2.47 & 1.86 & 2.71 & 2.11 & 1.41 & 2.10 & 1.88 & 2.04 & 1.79 & 2.29 & 2.47 & $1.7-2.7$ \\
\hline $\mathrm{P}_{2} \mathrm{O}_{5}$ & 0.37 & 0.32 & 0.33 & 0.34 & 0.28 & 0.35 & 0.28 & 0.23 & 0.20 & 0.29 & 0.19 & 0.21 & 0.30 & 0.23 & 0.18 & $0.18-0.37$ \\
\hline LOI & 1.10 & 0.90 & 0.80 & 0.50 & 1.10 & 1.07 & 1.14 & 0.90 & 0.90 & 0.98 & 1.10 & 0.67 & 0.65 & 1.10 & 0.97 & $0.5-1.14$ \\
\hline Total & 99.60 & 99.53 & 99.55 & 99.54 & 99.51 & 99.35 & 99.34 & 99.60 & 99.65 & 99.67 & 99.66 & 100.40 & 99.62 & 99.56 & 99.81 & $99.3-100.4$ \\
\hline $\mathrm{Rb}$ & 47 & 84 & 90 & 94 & 87 & 49 & 70 & 58 & 40 & 58 & 52 & 55 & 52 & 63 & 77 & $40-94$ \\
\hline $\mathrm{Ba}$ & 1222 & 1339 & 1234 & 1331 & 1388 & 1169 & 1573 & 1016 & 858 & 1021 & 878 & 841 & 1334 & 1184 & 863 & $841-1573$ \\
\hline $\mathrm{Sr}$ & 1259 & 886 & 888 & 860 & 1097 & 1062 & 861 & 957 & 783 & 927 & 680 & 806 & 1136 & 971 & 728 & $728-1259$ \\
\hline Th & 13.9 & 20.0 & 18.0 & 21.0 & 18.0 & 9.8 & 14.4 & 9.9 & 4.8 & 6.5 & 7.2 & 7.5 & 11.6 & 12.9 & 9.4 & $4.8-21$ \\
\hline $\mathrm{U}$ & 1.9 & 1.8 & 2.7 & 2.5 & 3.7 & 1.9 & 2.0 & 1.8 & 0.5 & 1.9 & 1.5 & 1.9 & 2.8 & 2.8 & 4.7 & $0.5-3.7$ \\
\hline $\mathrm{Ta}$ & 0.3 & 0.3 & 0.4 & 0.5 & 0.5 & 0.4 & 0.3 & 0.6 & 0.7 & 0.4 & 0.8 & 0.5 & 0.4 & 0.7 & 0.6 & $0.3-0.8$ \\
\hline $\mathrm{Nb}$ & 5 & 7 & 8 & 8 & 8 & 6 & 5 & 5 & 6 & 5 & 6 & 7 & 4 & 4 & 5 & $4.0-8.0$ \\
\hline $\mathrm{Zr}$ & 197 & 223 & 237 & 231 & 238 & 204 & 182 & 175 & 171 & 169 & 171 & 174 & 161 & 156 & 150 & $150-238$ \\
\hline $\mathrm{Hf}$ & 5 & 7 & 7 & 6 & 7 & 4 & 4 & 5 & 5 & 4 & 4 & 4 & 4 & 4 & 4 & $3.6-6.9$ \\
\hline Y & 16 & 20 & 19 & 19 & 20 & 17 & 13 & 13 & 19 & 13 & 19 & 15 & 11 & 13 & 11 & $11.0-20.0$ \\
\hline $\mathrm{Cr}$ & 246 & 144 & 137 & 144 & 137 & 70 & 180 & 82 & 55 & 73 & 62 & 110 & 90 & 144 & 112 & $55-246$ \\
\hline $\mathrm{Ni}$ & 101 & 84 & 66 & 56 & 62 & 20 & 72 & 40 & 20 & 30 & 20 & 70 & 30 & 58 & 53 & $20-101$ \\
\hline $\mathrm{v}$ & 109 & 108 & 109 & 112 & 94 & 82 & 83 & 73 & 90 & 73 & 87 & 88 & 79 & 78 & 64 & $64-112$ \\
\hline La & 79 & 170 & 110 & 77 & 60 & 79 & 59 & 26 & 28 & 37 & 42 & 33 & 35 & 24 & 31 & $24-170$ \\
\hline $\mathrm{Ce}$ & 145 & 257 & 200 & 128 & 122 & 155 & 108 & 64 & 57 & 70 & 59 & 60 & 78 & 48 & 59 & $48-257$ \\
\hline $\operatorname{Pr}$ & 15.8 & 29.1 & 19.9 & 15.5 & 13.6 & 17.3 & 11.8 & 6.8 & 7.0 & 7.9 & 8.6 & 7.8 & 9.0 & 5.1 & 7.3 & $5.1-29.1$ \\
\hline $\mathrm{Nd}$ & 59 & 109 & 71 & 59 & 55 & 50 & 45 & 26 & 28 & 31 & 30 & 25 & 28 & 19 & 26 & 19-109 \\
\hline $\mathrm{Sm}$ & 9.4 & 14.4 & 10.1 & 10.0 & 9.1 & 9.0 & 7.2 & 4.9 & 5.1 & 5.8 & 5.4 & 4.7 & 5.2 & 4.3 & 4.9 & $4.3-14.4$ \\
\hline $\mathrm{Eu}$ & 3.1 & 2.9 & 2.3 & 2.1 & 2.0 & 2.7 & 2.3 & 1.5 & 1.5 & 1.8 & 1.5 & 1.4 & 2.1 & 1.5 & 1.5 & $1.4-3.1$ \\
\hline $\mathrm{Gd}$ & 6.4 & 8.0 & 6.1 & 6.0 & 5.9 & 6.2 & 4.7 & 3.8 & 4.2 & 4.0 & 4.3 & 3.7 & 3.4 & 3.5 & 3.4 & $3.4-8.0$ \\
\hline $\mathrm{Tb}$ & 0.81 & 0.98 & 0.79 & 0.88 & 0.77 & 0.80 & 0.60 & 0.50 & 0.64 & 0.52 & 0.65 & 0.50 & 0.50 & 0.53 & 0.42 & $0.42-0.98$ \\
\hline Dy & 3.87 & 4.19 & 3.87 & 3.99 & 3.82 & 3.40 & 2.78 & 2.46 & 3.17 & 2.70 & 3.51 & 2.90 & 2.10 & 2.60 & 2.20 & $2.10-4.19$ \\
\hline Ho & 0.55 & 0.63 & 0.56 & 0.63 & 0.62 & 0.60 & 0.49 & 0.46 & 0.63 & 0.43 & 0.61 & 0.50 & 0.40 & 0.41 & 0.37 & $0.37-0.63$ \\
\hline $\mathrm{Er}$ & 1.36 & 1.47 & 1.43 & 1.49 & 1.58 & 1.50 & 1.19 & 1.17 & 1.66 & 1.14 & 1.81 & 1.40 & 0.90 & 1.04 & 0.94 & $0.90-1.47$ \\
\hline $\mathrm{Tm}$ & 0.18 & 0.22 & 0.24 & 0.23 & 0.23 & 0.19 & 0.16 & 0.17 & 0.26 & 0.17 & 0.27 & 0.21 & 0.13 & 0.17 & 0.12 & $0.12-0.22$ \\
\hline $\mathrm{Yb}$ & 1.09 & 1.44 & 1.43 & 1.33 & 1.45 & 1.10 & 0.95 & 1.06 & 1.62 & 1.02 & 1.68 & 1.30 & 0.80 & 1.08 & 0.88 & $0.80-1.45$ \\
\hline $\mathrm{Lu}$ & 0.16 & 0.19 & 0.21 & 0.22 & 0.22 & 0.15 & 0.16 & 0.15 & 0.24 & 0.15 & 0.26 & 0.19 & 0.11 & 0.16 & 0.14 & $0.11-0.24$ \\
\hline \multicolumn{17}{|l|}{ Locality } \\
\hline UTM N & $7,726,750$ & $7,712,649$ & $7,710,291$ & $7,709,100$ & $7,715,283$ & $7,717,635$ & $\begin{array}{l}7 \\
, 728,300\end{array}$ & $7,717,508$ & $7,712,545$ & $7,723,300$ & $7,711,026$ & $7,710,456$ & $7,718,899$ & $7,717,341$ & $7,727,050$ & \\
\hline UTM E & 608,500 & 637,590 & 648,554 & 643,300 & 638,375 & 615,680 & 618,300 & 601,123 & 603,504 & 613,800 & 602,389 & 615,456 & 616,500 & 599,486 & 621,000 & \\
\hline Laboratory & CRPG & ACME & ACME & ACME & ACME & ACTL & CRPG & ACME & ACME & CRPG & ACME & ACTL & ACTL & ACME & CRPG & \\
\hline
\end{tabular}


Table 6 (continued).

\begin{tabular}{|c|c|c|c|c|c|c|c|c|c|c|c|c|c|c|}
\hline \multirow[t]{2}{*}{ Sample } & \multicolumn{10}{|c|}{ Dioritic MME } & \multicolumn{4}{|l|}{ Averages } \\
\hline & E1 & E2 & E3 & E4 & E5 & E6 & E7 & E8 & E9 & Range & T1-T15 & T1-T6 & T7-T15 & E1-E9 \\
\hline $\mathrm{SiO}_{2}$ & 54.60 & 53.43 & 53.63 & 53.62 & 53.28 & 51.37 & 51.62 & 50.53 & 47.66 & $47.7-54.6$ & 62.4 & 60.8 & 63.5 & 50.89 \\
\hline $\mathrm{TiO}_{2}$ & 0.80 & 0.90 & 0.67 & 0.79 & 1.06 & 1.17 & 1.07 & 1.02 & 1.13 & $0.67-1.13$ & 0.7 & 0.7 & 0.6 & 1.09 \\
\hline $\mathrm{Al}_{2} \mathrm{O}_{3}$ & 16.36 & 15.87 & 14.41 & 13.72 & 14.47 & 14.77 & 14.15 & 10.78 & 13.87 & $10.8-16.4$ & 15.5 & 15.5 & 15.5 & 13.61 \\
\hline $\mathrm{Fe}_{2} \mathrm{O}_{3 \mathrm{t}}$ & 7.85 & 8.23 & 10.69 & 8.72 & 9.02 & 9.26 & 9.05 & 9.03 & 12.49 & $7.8-12.5$ & 5.4 & 5.8 & 5.1 & 9.77 \\
\hline $\mathrm{MnO}$ & 0.12 & 0.13 & 0.23 & 0.18 & 0.14 & 0.03 & 0.16 & 0.15 & 0.18 & $0.12-0.23$ & 0.1 & 0.1 & 0.1 & 0.13 \\
\hline $\mathrm{MgO}$ & 5.77 & 6.86 & 4.94 & 7.82 & 7.39 & 7.95 & 6.09 & 11.68 & 7.51 & $4.9-11.7$ & 3.3 & 3.9 & 2.9 & 8.12 \\
\hline $\mathrm{CaO}$ & 7.08 & 7.23 & 8.81 & 6.95 & 6.76 & 7.40 & 9.51 & 7.83 & 7.04 & $6.8-9.5$ & 4.5 & 5.0 & 4.2 & 7.71 \\
\hline $\mathrm{Na}_{2} \mathrm{O}$ & 4.62 & 3.96 & 3.91 & 3.85 & 3.58 & 3.68 & 3.25 & 2.60 & 2.97 & $2.6-4.6$ & 4.4 & 4.3 & 4.5 & 3.22 \\
\hline $\mathrm{K}_{2} \mathrm{O}$ & 0.97 & 1.31 & 1.16 & 2.40 & 2.24 & 2.31 & 2.50 & 2.79 & 3.55 & $0.97-3.6$ & 2.2 & 2.3 & 2.1 & 2.68 \\
\hline $\mathrm{P}_{2} \mathrm{O}_{5}$ & 0.26 & 0.30 & 0.55 & 0.46 & 0.46 & 0.55 & 1.15 & 0.94 & 1.08 & $0.26-1.15$ & 0.3 & 0.3 & 0.2 & 0.84 \\
\hline LOI & 1.20 & 1.50 & 0.67 & 1.26 & 1.20 & 1.09 & 1.33 & 1.70 & 1.59 & $0.67-1.7$ & 0.9 & 0.9 & 0.9 & 1.4 \\
\hline Total & 99.63 & 99.72 & 99.67 & 99.77 & 99.60 & 99.58 & 99.88 & 99.05 & 99.07 & $99.1-99.9$ & 99.6 & 99.5 & 99.7 & 99.5 \\
\hline $\mathrm{Rb}$ & 28 & 40 & 26 & 78 & 67 & 58 & 69 & 82 & 122 & $26-122$ & 65 & 75 & 58 & 79 \\
\hline Ва & 714 & 941 & 508 & 513 & 1388 & 1573 & 1020 & 1359 & 868 & $508-1573$ & 1150 & 1281 & 1063 & 1242 \\
\hline $\mathrm{Sr}$ & 1062 & 1100 & 694 & 554 & 1319 & 1272 & 800 & 1511 & 600 & $554-1511$ & 927 & 1009 & 872 & 1100 \\
\hline Th & 1.0 & 3.0 & 17.8 & 11.5 & 19.1 & 20.5 & 22.6 & 8.8 & 55.2 & $1.0-55.0$ & 12.3 & 16.8 & 9.3 & 25.2 \\
\hline $\mathrm{U}$ & 0.6 & 1.3 & 3.7 & 2.6 & 2.6 & 2.6 & 6.2 & 2.0 & 8.1 & $0.6-8.1$ & 2.3 & 2.4 & 2.2 & 4.3 \\
\hline Та & 0.2 & 0.2 & 0.3 & 0.4 & 0.4 & 0.7 & 0.5 & 0.2 & 0.4 & $0.2-0.7$ & 0.5 & 0.4 & 0.6 & 0.4 \\
\hline $\mathrm{Nb}$ & 6 & 5 & 6 & 6 & 6 & 8 & 11 & 6 & 11 & $41,583.00$ & 6 & 7 & 5 & 9 \\
\hline $\mathrm{Zr}$ & 133 & 176 & 239 & 205 & 250 & 275 & 393 & 267 & 511 & $133-511$ & 189 & 222 & 168 & 339 \\
\hline $\mathrm{Hf}$ & 3 & 5 & 7 & 5 & 6 & 6 & 9 & 6 & 12 & $3.1-11.7$ & 5 & 6 & 4 & 8 \\
\hline $\mathrm{Y}$ & 19 & 22 & 22 & 25 & 22 & 22 & 43 & 30 & 59 & $19-59$ & 16 & 18 & 14 & 35 \\
\hline $\mathrm{Cr}$ & 178 & 253 & 230 & 383 & 267 & 290 & 189 & 773 & 428 & $176-773$ & 119 & 146 & 101 & 389 \\
\hline $\mathrm{Ni}$ & 65 & 137 & 80 & 233 & 146 & 150 & 30 & 359 & 95 & $65-359$ & 52 & 65 & 44 & 156 \\
\hline V & 152 & 166 & 108 & 125 & 155 & 158 & 184 & 148 & 222 & $108-222$ & 89 & 102 & 79 & 173 \\
\hline La & 26 & 31 & 50 & 65 & 134 & 66 & 156 & 109 & 282 & $26-282$ & 59 & 96 & 35 & 149 \\
\hline $\mathrm{Ce}$ & 64 & 79 & 112 & 127 & 243 & 153 & 309 & 242 & 540 & $64-540$ & 107 & 168 & 67 & 297 \\
\hline $\operatorname{Pr}$ & 7.9 & 9.8 & 14.0 & 15.3 & 25.6 & 19.0 & 38.4 & 31.0 & 68.7 & $7.9-68.7$ & 12.2 & 18.5 & 7.9 & 36.5 \\
\hline $\mathrm{Nd}$ & 34 & 44 & 51 & 59 & 96 & 64 & 160 & 123 & 243 & $34-343$ & 44 & 67 & 29 & 137 \\
\hline $\mathrm{Sm}$ & 6.1 & 8.1 & 11.1 & 11.8 & 13.5 & 12.6 & 30.0 & 23.3 & 44.1 & $6.1-44.1$ & 7.3 & 10.3 & 5.3 & 24.7 \\
\hline $\mathrm{Eu}$ & 2.0 & 2.2 & 1.8 & 1.9 & 3.2 & 3.9 & 5.3 & 5.9 & 4.5 & $1.8-5.9$ & 2.0 & 2.5 & 1.7 & 4.6 \\
\hline Gd & 4.8 & 6.2 & 8.5 & 8.2 & 7.1 & 8.3 & 21.0 & 15.7 & 29.6 & $4.8-29.6$ & 4.9 & 6.4 & 3.9 & 16.3 \\
\hline $\mathrm{Tb}$ & 0.66 & 0.85 & 1.00 & 0.98 & 0.96 & 1.00 & 2.39 & 1.84 & 3.19 & $0.66-3.19$ & 0.66 & 0.84 & 0.54 & 1.88 \\
\hline Dy & 3.42 & 4.37 & 4.50 & 5.19 & 4.58 & 4.70 & 10.57 & 6.82 & 14.31 & $3.42-14.31$ & 3.17 & 3.86 & 2.71 & 8.20 \\
\hline Ho & 0.61 & 0.71 & 0.80 & 0.81 & 0.76 & 0.80 & 1.65 & 1.01 & 1.90 & $0.61-1.90$ & 0.53 & 0.60 & 0.48 & 1.22 \\
\hline $\mathrm{Er}$ & 1.75 & 2.08 & 2.10 & 1.96 & 1.89 & 2.20 & 3.58 & 2.17 & 5.07 & $1.75-5.07$ & 1.34 & 1.47 & 1.25 & 2.98 \\
\hline $\mathrm{Tm}$ & 0.22 & 0.28 & 0.28 & 0.29 & 0.30 & 0.30 & 0.41 & 0.32 & 0.50 & $0.22-0.50$ & 0.20 & 0.21 & 0.18 & 0.37 \\
\hline $\mathrm{Yb}$ & 1.51 & 1.71 & 1.60 & 1.87 & 2.14 & 1.80 & 2.43 & 1.78 & 3.55 & $1.51-3.55$ & 1.22 & 1.31 & 1.15 & 2.34 \\
\hline Lu & 0.26 & 0.25 & 0.23 & 0.31 & 0.27 & 0.24 & 0.38 & 0.24 & 0.52 & $0.26-0.52$ & 0.18 & 0.19 & 0.17 & 0.33 \\
\hline \multicolumn{15}{|l|}{ Locality } \\
\hline UTM N & $7,710,291$ & $7,710,291$ & $7,721,100$ & $7,727,050$ & $7,718,823$ & $7,718,899$ & $7,728,300$ & $7,718,796$ & $7,727,050$ & & & & & \\
\hline UTM E & 648,554 & 648,554 & 617,750 & 621,000 & 616,451 & 616,500 & 618,300 & 598,040 & 621,000 & & & & & \\
\hline Laboratory & ACME & ACME & ACTL. & CRPG & ACTL. & ACTL. & CRPG & ACME & CRPG & & & & & \\
\hline
\end{tabular}



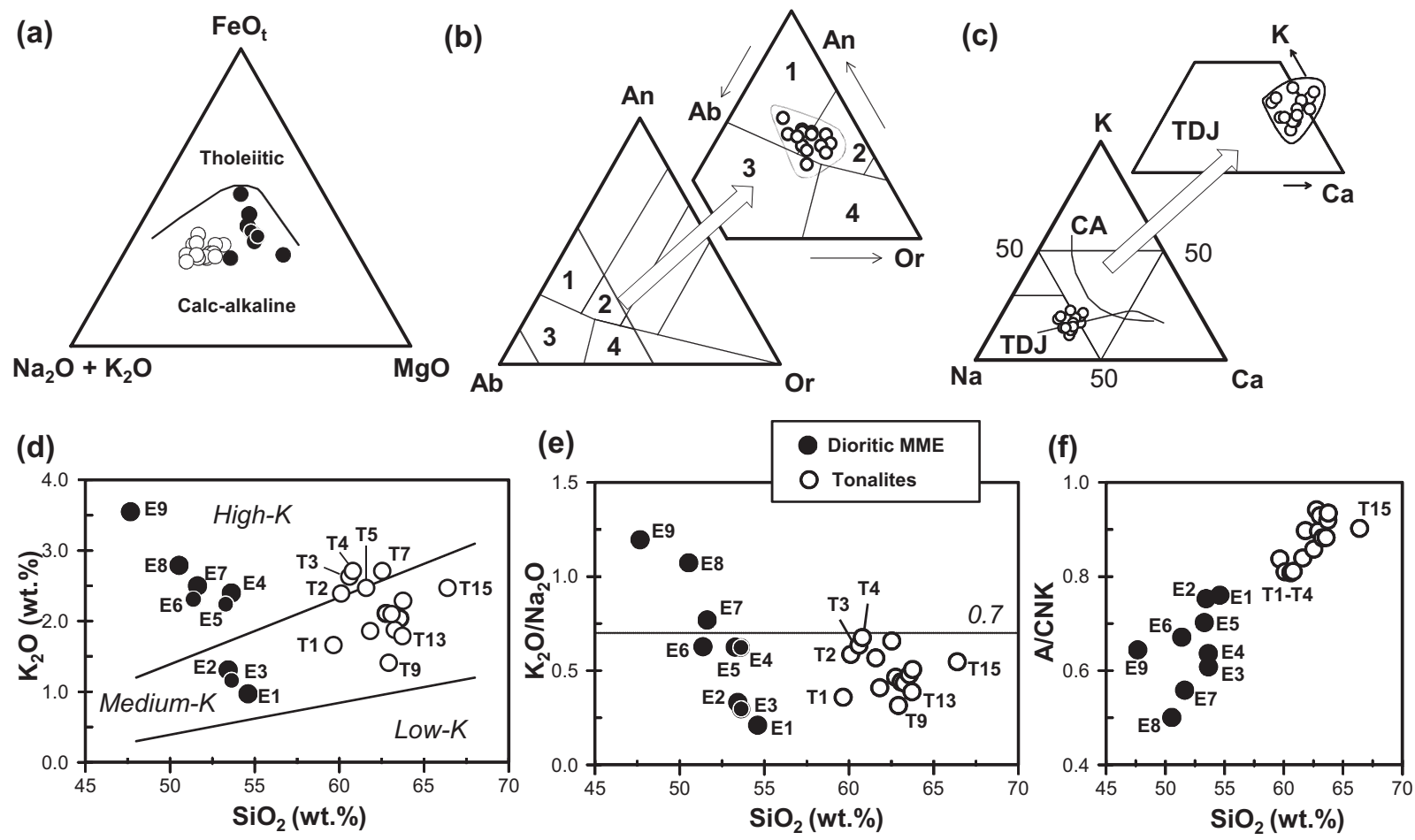

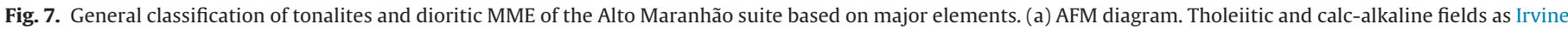

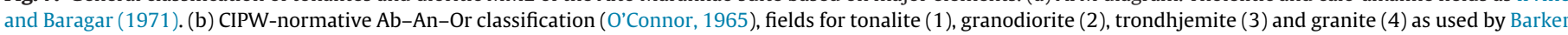

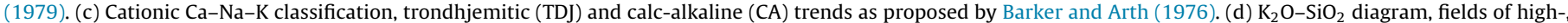
medium- and low-K series from Le Maitre (2002). (e) $\mathrm{K}_{2} \mathrm{O} / \mathrm{Na}_{2} \mathrm{O}$ ratio versus $\mathrm{SiO}_{2}$ and (f) $\mathrm{A} / \mathrm{CNK}$ versus $\mathrm{SiO}_{2}$. Legend in (e).

Maranhão suite indicates that the metasomatism of the mantle source of the latter could have been produced by materials like that of the Lagoa Dourada suite.

Further evidence for a mantle source metasomatised by slabderived melts is tentatively suggested by chemical and textural aspects of the clinopyroxene xenocryst found within tonalite of the T7 work station (Table 3 and Fig. 4). The high Mg-number, high chromium contents, and centimetric size (minimum of $1.3 \mathrm{~cm} \times 1.3 \mathrm{~cm}$; Fig. 4a) suggest that the clinopyroxene megacryst was incorporated as an intratelluric xenocryst into the tonalitic host magma. In that sense, the overall major element composition of the xenocryst is similar to compositions of clinopyroxenes found as xenocrysts incorporated into high-Mg andesites and/or adakites in modern subduction zones. An ultimate origin from a mantle wedge assemblage modified by interaction with slabderived melts was demonstrated for these magmas (Fig. 12 and references therein). In addition, the ${ }^{[\mathrm{IV}]} \mathrm{Al}+\mathrm{Na} \leftrightarrow 2 \mathrm{Si}$ substitution, synchronous with increasing $\mathrm{Mg}$-number and $\mathrm{Ca}$ from core to some external zones (Fig. 4c), may have resulted from reaction with adakitic-like melt (i.e. high-Na/K, high-aluminium, high-Mg, intermediate andesitic-dacitic liquid; see for example Kepezhinskas et al., 1995; Rapp et al., 2010). However, fluids must also have been involved. Internal alteration into high-Mg and high-Cr amphibole patches with phlogopitic mica, and calcite microveins (Fig. 4a) are interpreted as evidence of reaction with potassic fluids bearing volatiles, such as $\mathrm{H}_{2} \mathrm{O}$ and $\mathrm{CO}_{2}$, before being incorporated into the host magma.

\subsection{Parent magmas}

From the above mentioned field, petrographical, mineralogical, geochemical and isotopic (Nd) data, the tonalites and dioritic MME of the Alto Maranhão suite can be considered as cogenetic rocks. In this sense the suite is classified as a high-Mg granitoid (i.e., tonalitic-dioritic) suite akin with the Late-Archaean mantlederived sanukitoids (Shirey and Hanson, 1984; Sutcliffe et al., 1990; Stern and Hanson, 1991; Evans and Hanson, 1997; Stevenson et al., 1999; Smithies and Champion, 2000; Martin et al., 2005; Heilimo et al., 2010; Oliveira et al., 2011), although somewhat atypical because of missing of terms with more abundant k-feldspar (i.e., monzodiorites and k-feldspar porphyritic monzogranites), which are common rock types of the latter. Identifying possible parent magma compositions for the Alto Maranhão suite must take into account the following: First, tonalites and dioritic MME are related in the field mainly by means of mingling (not mixing) structures, thus indicating that these two lithologies evolved from separate batches of magma. This implies that the suite was composed of at least two major parent magmas, a main one for the tonalites and a subsidiary magma for the dioritic MME. Second, petrographic data (e.g., hornblende included in plagioclase; clusters of accessory minerals included in all other phases), mineral chemistry (e.g., chemical zonation within hornblende and plagioclase, as well as within allanite and zircon) and coherent trends on Harker-like diagrams clearly show that the chemical variation observed for both group of lithologies reflects at least partially the effects of magmatic differentiation. Differentiation was most probably controlled by fractional crystallization of early crystallizing phases (i.e. hornblende and accessory minerals), followed by biotite and/or plagioclase - see also next section. Consequently, rock samples with evident geochemical signs of crystal accumulation and/or the most fractionated must be discarded from consideration in constraining the parental magma compositions. Finally, the sampling for this study encompasses more than one tonalite pluton (e.g. samples T9/T11; sample T12; samples T6/T13, and so, Fig. 1c), which although appertaining to the same suite, show in detail slightly different geochemical characteristics. The same must be envisaged 

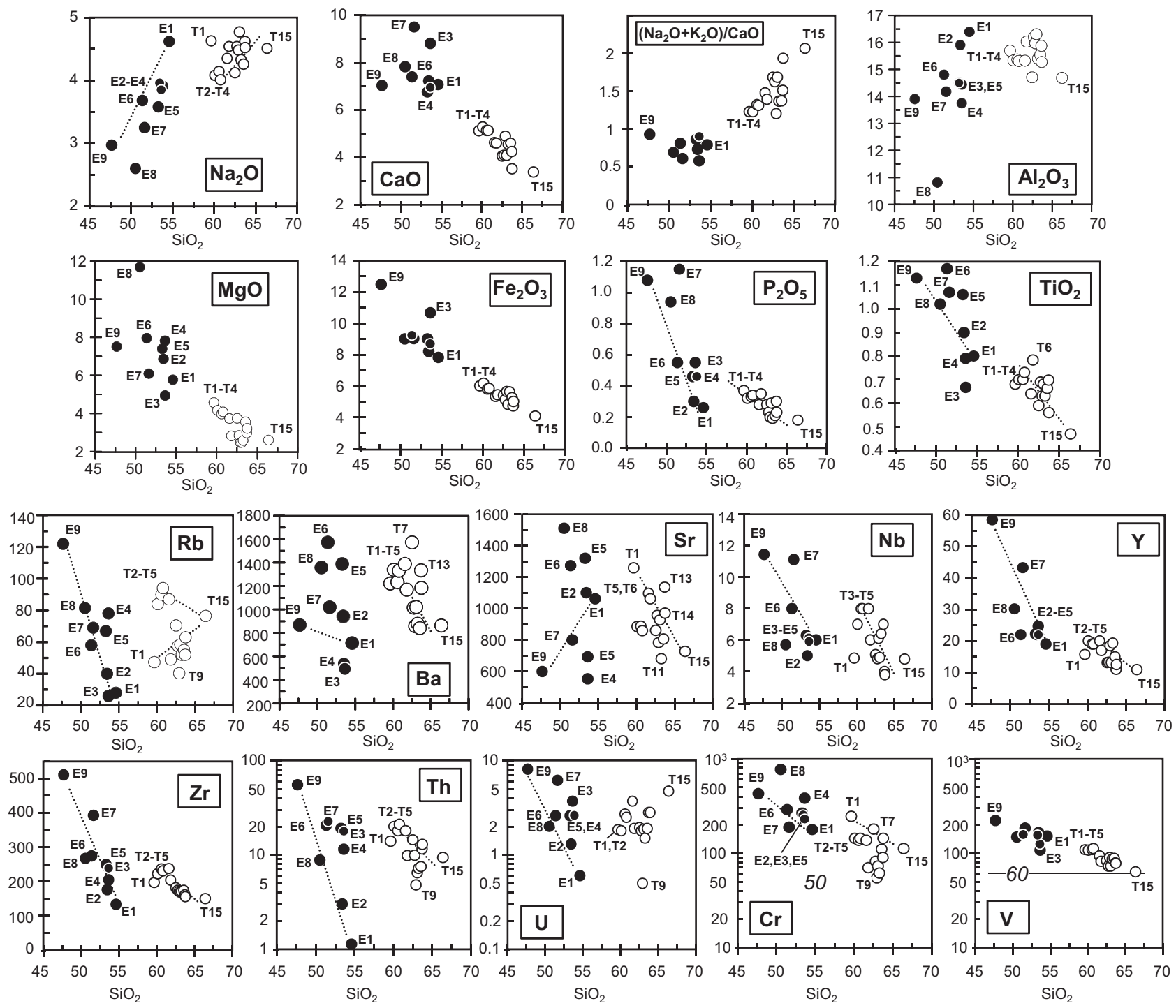

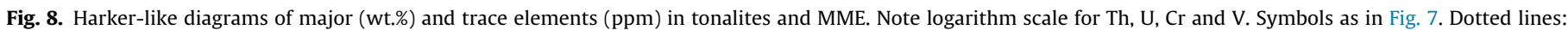
parallel trends discussed in Section 5.3. Magmatic evolution.

for the enclaves. Then, the following discussion is considered only an approximative approach to constrain the nature of the parent magmas of the suite.

Considering the enclaves, the sample E1 was chosen as closest to representing the parent magma. This is simply due to the fact that this sample displays the lowest contents in incompatible trace elements that have $K_{\mathrm{D}} \gg 1$ relative to hornblende, biotite and accessory minerals (i.e., LILE, HFSE and REE, $K_{\mathrm{D}} \mathrm{S}$ as in Rollinson, 1993 and/or in Bédard, 2006). Petrographically, the sample E1 has the lowest mafic and accessory mineral content, and the highest $\mathrm{Hbl} / \mathrm{Bt}$ ratio among the dioritic MME (Fig. 2a-c and Table 1). Simptomatic is the lowest vol.\% of allanite (by modal counting) of the samples E1/E2. The Mg-number (0.59), the $\mathrm{Cr}$ content $(178 \mathrm{ppm})$ and the primitive mantle-normalized profile of sample E1 correspond well to the composition of a primary high-Mg andesite (Fig. 13b). Its silica (54.6 wt.\% $\mathrm{SiO}_{2}$ ) and total alkali (5.6 wt.\% $\mathrm{Na}_{2} \mathrm{O}+\mathrm{K}_{2} \mathrm{O}$ ) contents define a rock on the boundary line between basaltic andesite and basaltic trachyandesite of the TAS classification diagram of volcanic rocks (Le Maitre, 2002, not shown). The REE modelling (Fig. 13d) shows a good fit for $\sim 23 \%$ partial melting of a TTG-metasomatised mantle source ( $50 \%$ TTG/50\% primitive mantle) left behind a websteritic residue composed by $90 \% \mathrm{Opx}+10 \% \mathrm{Cpx}$. This result is in agreement with the proposed source for Archaean high-Mg dioritic suites of Pilbara Craton, Western Australia (e.g. the fine-grained melanodiorite of Jones Well Stock, Smithies and Champion, 2000). The modelling also shows that for generating the other enclave compositions, with the same source, will need unrealistic lower degrees of melting. This is the case of the sample E9, which by contrast with the sample $\mathrm{E} 1$ presents the lowest silica content $\left(47.6 \mathrm{wt} . \% \mathrm{SiO}_{2}\right)$, yields the highest content in both compatible $(\mathrm{Cr}, \mathrm{Ni}, \mathrm{V})$ and incompatible trace elements, i.e., LILE ( $\mathrm{K}$ and $\mathrm{Rb}$, with the exception of $\mathrm{Sr}$ which is depleted relatively to sample E1), REE and HFSE (see the primitive mantle-normalized diagram of Fig. 13b). Therefore, the mechanism proposed to generate the peculiar composition of the sample E9 is not the partial melting process from the same source of the sample E1. It will be postulated this sample to be a result of the accumulation of mafic (hornblende + biotite) and accessory (allanite + apatite + zircon) minerals, in the absence of plagioclase (Sr depletion, see also Section 5.3). This is supported by the peculiar modal composition of the sample E9, with the highest mafic and accessory mineral content, and the lowest $\mathrm{Hbl} / \mathrm{Bt}$ ratio (i.e., the highest vol.\% of biotite) among the dioritic MME (Fig. 2a-c and Table 1). 

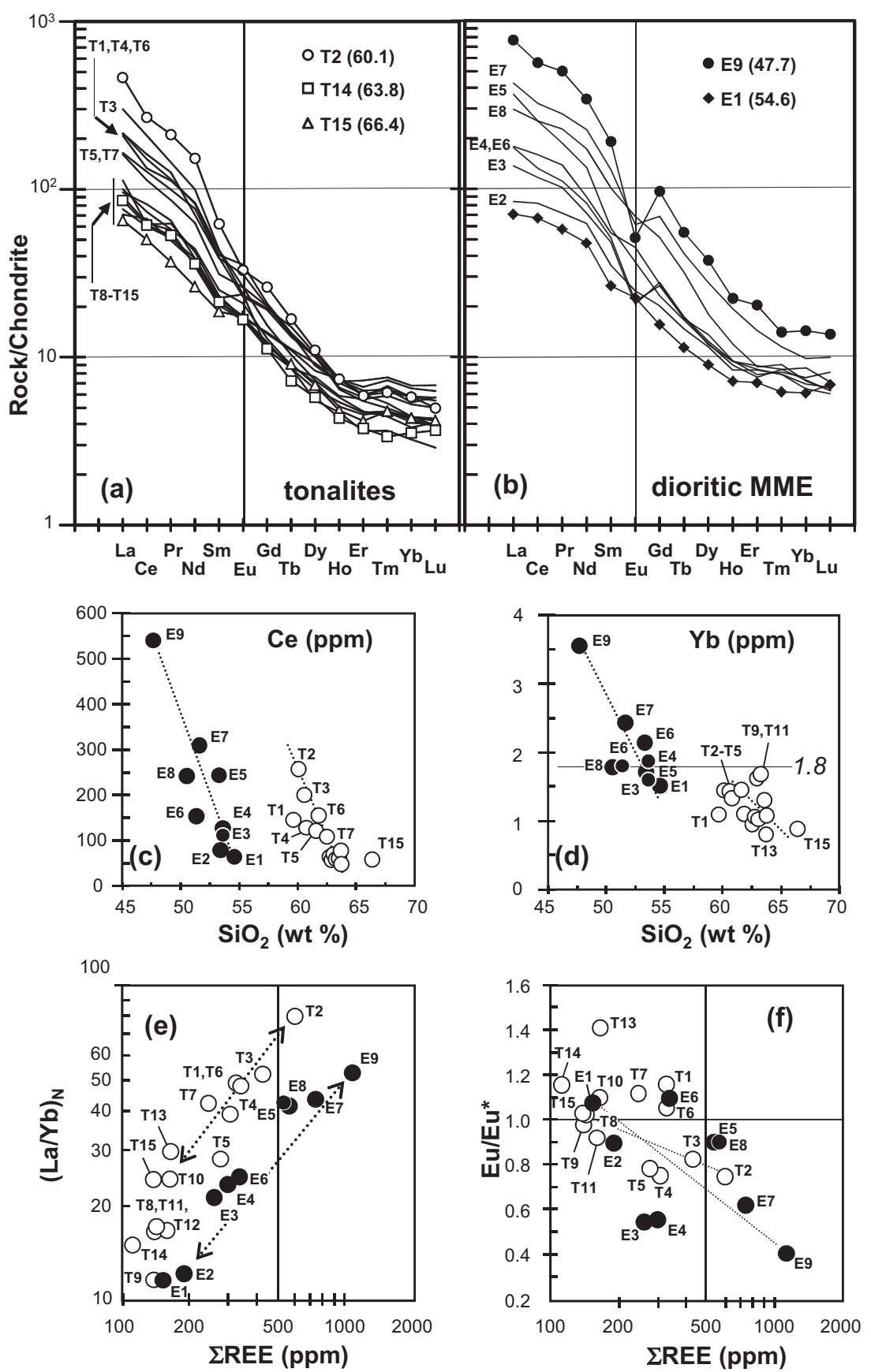

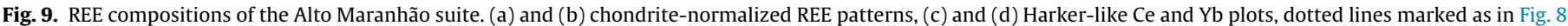

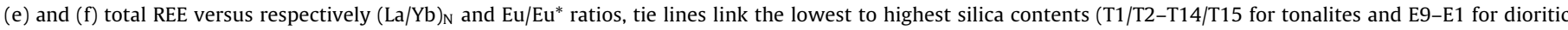
MME). Chondrite values after Taylor and McLennan (1985). Symbols as in Fig. 7. See Section 5.3. Magmatic evolution for discussion.

Now taking in account the tonalite data, the most primitive are the samples T1-T4, with the highest Mg-number $(\geq 0.57-0.60)$, $\mathrm{Cr}(\geq 137-246 \mathrm{ppm})$ and $\mathrm{Ni}(\geq 56-101 \mathrm{ppm})$ contents (Table 5 ). These samples are the tonalites with the highest mafic and accessory mineral content, and with the highest $\mathrm{Hbl} / \mathrm{Bt}$ ratios (i.e., 1.6-1.1, Fig. 2a-c). Furthermore, in the primitive mantlenormalized diagrams, these samples display crossing profiles with respect to the more siliceous samples in terms of $\mathrm{Eu} / \mathrm{Eu}^{*}$, $\mathrm{Sr} / \mathrm{Sr}^{*}$ and $\mathrm{Th} / \mathrm{Th}^{*}$ anomalies (calculated from neighbouring element abundances, Fig. 10). Therefore, they could reflect, at least partially, the effect of mineral accumulation processes. In order to minimize these effects, it was arbitrarily fixed the average of the compositions of the least fractionated tonalitic samples - i.e., T1-T6 samples, all with wt.\% $\mathrm{SiO}_{2}<62$ - as a reference frame for the hypothetical parent magma composition. This composition corresponds to $60.8 \mathrm{wt} . \% \mathrm{SiO}_{2}, \mathrm{Mg}$-number $=0.57$, $\mathrm{Cr}=146 \mathrm{ppm}$, and yields a primitive mantle-normalized pattern similar to the average composition of the low-Ti, least fractionated (plutonic) sanukitoids (Fig. 13a; composition listed in Table 6, sanukitoid data from Martin et al., 2010). REE modelling of this composition shows a good fit for $\sim 13 \%$ partial melting of a TTGmetasomatised mantle source ( $50 \%$ TTG/50\% primitive mantle) left behind a websteritic residue composed by $75 \% \mathrm{Opx}+25 \%$ Olv (Fig. 13c). 

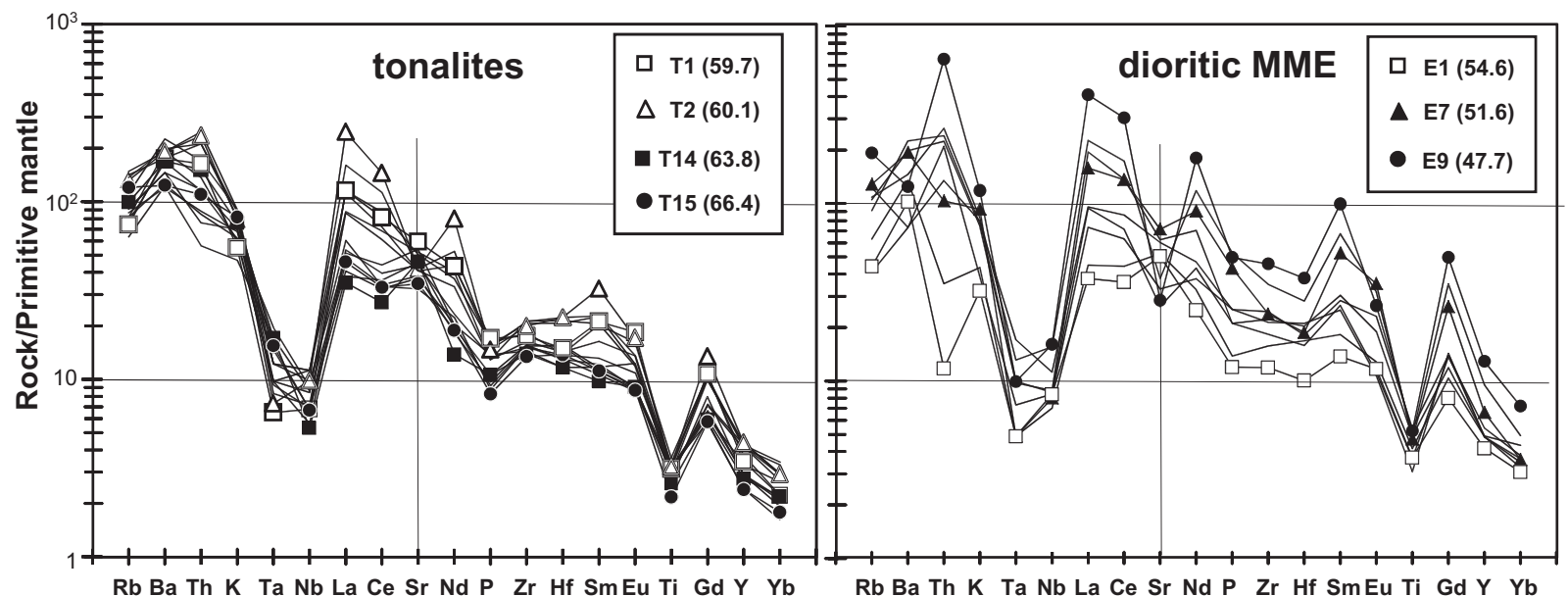

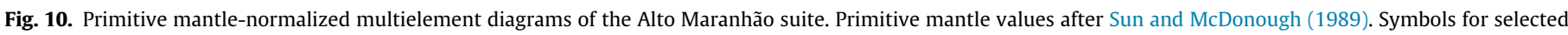
rocks are indicated, with $\mathrm{SiO}_{2}$ contents (wt.\%) in brackets.

Table 7

Summary of selected petrochemical parameters of tonalites and dioritic MME, Alto Maranhão suite.

\begin{tabular}{|c|c|c|}
\hline & Tonalites $(n=15)$ & $\operatorname{MME}^{\mathrm{a}}(n=9)$ \\
\hline Age U-Pb & $2130 \mathrm{Ma}$ & Same as tonalites \\
\hline $\mathrm{Nd}$ isotopes & $\varepsilon_{\mathrm{Nd}}(t) \approx \mathrm{CHUR} \pm 1.0$ & Same as tonalites \\
\hline Rock types & Bt-Hbl To ( \pm QzDi, Grd) & Bt-Hbl Di and QzDi \\
\hline $\mathrm{Ab}-\mathrm{An}-\mathrm{Or}^{\mathrm{b}}$ & To-Grd normative & not applied \\
\hline Acc. minerals & $\begin{array}{l}\text { Zrn, Ap, Ilm, Aln, } \pm \text { Mag, Ttn, } \\
\text { Cpy, Po, Ptn, Py }\end{array}$ & Same as tonalites \\
\hline \multicolumn{3}{|l|}{ Major elements } \\
\hline $\mathrm{SiO}_{2}(\mathrm{wt} . \%)$ & $59.7-66.4$ & $47.7-54.6$ \\
\hline $\mathrm{A} / \mathrm{CNK}$ index & $\begin{array}{l}\text { Metaluminous; } \\
\text { A/CNK incr. with diff. }\end{array}$ & Metaluminous; decr. to BHA \\
\hline $\mathrm{Al}_{2} \mathrm{O}_{3}$ (wt.\%) & $\geq 14.7$ & 16.4 , decr. to 10.8 to $\mathrm{BHA}$ \\
\hline $\mathrm{K}_{2} \mathrm{O}$ versus $\mathrm{SiO}_{2}{ }^{\mathrm{c}}$ & Medium-K & Medium-K, high-K to BHA \\
\hline $\mathrm{K}_{2} \mathrm{O} / \mathrm{Na}_{2} \mathrm{O}$ & $\leq 0.7 ;$ scatt. with diff. & $0.2 ;$ incr. to 1.2 to $\mathrm{BHA}$ \\
\hline $\mathrm{Na}_{2} \mathrm{O}$ (wt.\%) & $\geq 4.0$ & 4.6; decr. to 2.6 to BHA \\
\hline Plag. comp. & oligoclase to albite & oligoclase \\
\hline $\mathrm{MgO}(w \mathrm{t} . \%)$ & $\geq 2.5$ & $\geq 5.8$ \\
\hline Mg-number & $0.46 \leq \mathrm{Mg}$-number $\leq 0.60$ & $0.48 \leq \mathrm{Mg}$-number $\leq 0.72$ \\
\hline \multicolumn{3}{|l|}{ Trace elements } \\
\hline $\mathrm{Cr}(\mathrm{ppm})$ & $\geq 55$ to 246 ; decr. with diff. & $\geq 178$; incr. up to 772 to $\mathrm{BHA}$ \\
\hline LILE (ppm) & $\begin{array}{l}\mathrm{Rb}(\leq 94 \text { to } 40), \mathrm{Ba}(\geq 841 \text { to } 1573), \mathrm{Sr} \\
(\geq 728 \text { to } 1259)\end{array}$ & $\begin{array}{l}\mathrm{Rb}(\leq 122 \text { to } 26), \mathrm{Ba}(\geq 508 \text { to } 1573) \\
\mathrm{Sr}(\geq 554 \text { to } 1511) .\end{array}$ \\
\hline $\mathrm{Rb} / \mathrm{Sr}$ & $0.04-0.11 ;$ scatt. with diff. & $\begin{array}{l}0.03 \text {; incr. up to } 0.20 \\
\text { to BHA }\end{array}$ \\
\hline $\mathrm{K} / \mathrm{Rb}$ & 236-319; scatt. with diff. & $\begin{array}{l}\text { High } \geq 242 \\
\text { incr. up to } 371 \text { to BHA }\end{array}$ \\
\hline $\mathrm{Sr} / \mathrm{Ba}$ & $0.55-1.03$; scatt.with diff. & 1.5 ; decr. to 0.7 to BHA \\
\hline REE total (ppm) & 111-599; decr. with diff. & 153 ; incr. up to 1240 to BHA \\
\hline HREE (Yb ppm) & $1.45-0.88$; decr. with diff. & 1.5 ; incr. up to 3.6 to $\mathrm{BHA}$ \\
\hline$(\mathrm{La} / \mathrm{Yb})_{\mathrm{N}}$ & 80-12; decr. with diff. & $12 ;$ incr. up to 54 to BHA \\
\hline$(\mathrm{La} / \mathrm{Sm})_{\mathrm{N}}$ & 7.4-2.3; decr. with diff. & 2.4 ; incr. up to 6.3 to $\mathrm{BHA}$ \\
\hline$(\mathrm{Gd} / \mathrm{Yb})_{\mathrm{N}}$ & 4.7-2.1; decr. with diff. & 2.6 ; incr. up to 7.1 to $\mathrm{BHA}$ \\
\hline HFSE (ppm) & $\begin{array}{l}\text { Th (21-6.5), Nb (8-4), } \mathrm{Zr}(238-150), \mathrm{Y} \\
(20-11) \text {; } \\
\text { all decr. with diff. }\end{array}$ & $\begin{array}{l}\text { Th }(1.0-55), \mathrm{Nb}(5-11) \\
\mathrm{Zr}(133-511), \mathrm{Y}(19-59) \\
\text { all incr. to BHA }\end{array}$ \\
\hline \multicolumn{3}{|l|}{ LILE/HFSE } \\
\hline $\mathrm{Ba} / \mathrm{La}$ & $8-49$; incr. with diff. & 28; decr. up to 3 to $\mathrm{BHA}$ \\
\hline Th/La & $0.1-0.5$; scatt. with diff. & 0.04 ; incr. up to 0.4 to $\mathrm{BHA}$ \\
\hline $\mathrm{Sr} / \mathrm{Nd}$ & $8-52 ;$ incr. with diff. & $31 ;$ decr. to 2 to $\mathrm{BHA}$ \\
\hline $\mathrm{La} / \mathrm{Sm}$ & 12-5; decr. with diff. & 4 ; incr. up to 10 to $\mathrm{BHA}$ \\
\hline $\mathrm{Sr} / \mathrm{Y}$ & $35-103$; incr. or decr. with diff. & 56; decr. to 10 to $\mathrm{BHA}$ \\
\hline
\end{tabular}

a BHA refers to dioritic MME crystallized with accumulative biotite + hornblende + accessory minerals, allanite, zircon, apatite and ilmenite/titanite. Sample E1 is assumed to be non cumulus and to represent the parental magma of the dioritic MME (see discussion text). This sample is used as the reference for the other compositions.

b Classification according to Barker (1979): To, tonalite; Grd, granodiorite.

c Classification according to Le Maitre (2002). 


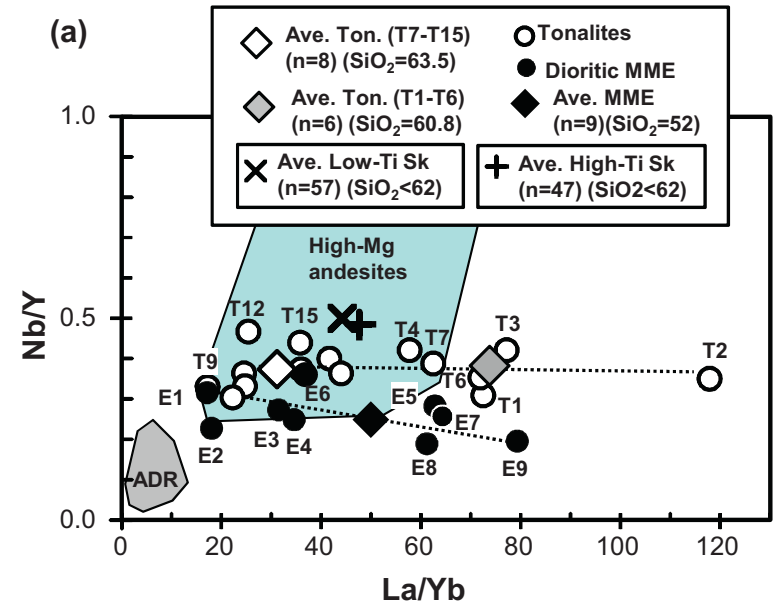

(b)

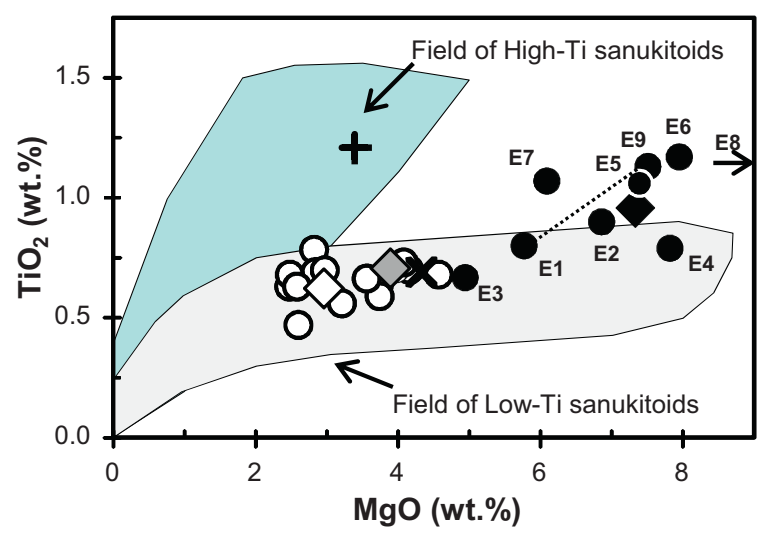

Fig. 11. (a) $\mathrm{Nb} / \mathrm{Y}$ versus $\mathrm{La} / \mathrm{Yb}$ and (b) $\mathrm{wt} \% \mathrm{TiO}_{2}$ versus wt.\% $\mathrm{MgO}$ plot of tonalites and dioritic MME of the Alto Maranhão suite. Tie lines as in Fig. 8. In (a) $\mathrm{ADR}=$ andesite-dacite-rhyolite, field of arc magmas generated by melting of mantle peridotite metasomatised by fluids. High-Mg andesites: field of modern high-Mg andesites considered to be generated by melting of mantle peridotite metasomatised by felsic melts. Average of low- $(n=57)$ and high-Ti $(n=47)$ sanukitoids (Sk) are indicated (see also Section 5.2. Parent magmas). Adapted from Martin et al. (2010).

\subsection{Magmatic evolution}

Two remarkable aspects of the geochemistry of the Alto Maranhão suite are the gap in the silica contents (between $\sim 54.6$ and $59.6 \mathrm{wt} . \% \mathrm{SiO}_{2}$ ) and the parallel trends, with approximately similar slopes, in Harker-like diagrams for some major and trace element (e.g., $\mathrm{Na}_{2} \mathrm{O}, \mathrm{MgO}, \mathrm{P}_{2} \mathrm{O}_{5}, \mathrm{TiO}_{2}, \mathrm{Rb}, \mathrm{Ba}, \mathrm{Sr}, \mathrm{Nb}, \mathrm{Y}, \mathrm{Zr}, \mathrm{Th}, \mathrm{Cr}$, Ce and $\mathrm{Yb}$; Figs. 8 and 9). They reinforce the previous arguments that dioritic MME and tonalite hosts are not related by mixing (i.e., there are no hybrid compositions), and that their chemical compositions result from independent liquid lines of descent of two discrete parent magmas, although controlled by the same minerals. Microprobe data show that both lithologies have major and accessory minerals with similar compositions. In this sense, the wt.\% $\mathrm{CaO}$ versus Mg-number diagram of Fig. 14 shows that, if there is a $\sim 1.0 \mathrm{wt} \%$ gap in $\mathrm{CaO}$ between tonalites and MME, with MME yielding the maximum values, there is also an overlap in terms of Mg-numbers; even though the higher values are found in MME and the lower values in tonalites. The least siliceous and more mafic dioritic MME were most probably formed by accumulation of mafic minerals, thus explaining why rocks of very different silica contents can have overlapping Mg-numbers. In the context of the geological situation investigated in this study, where the enclaves must reflect different stages of mingling within the felsic chamber, the term "cumulate" is employed in the sense of Kelemen et al. (2004) to mean a

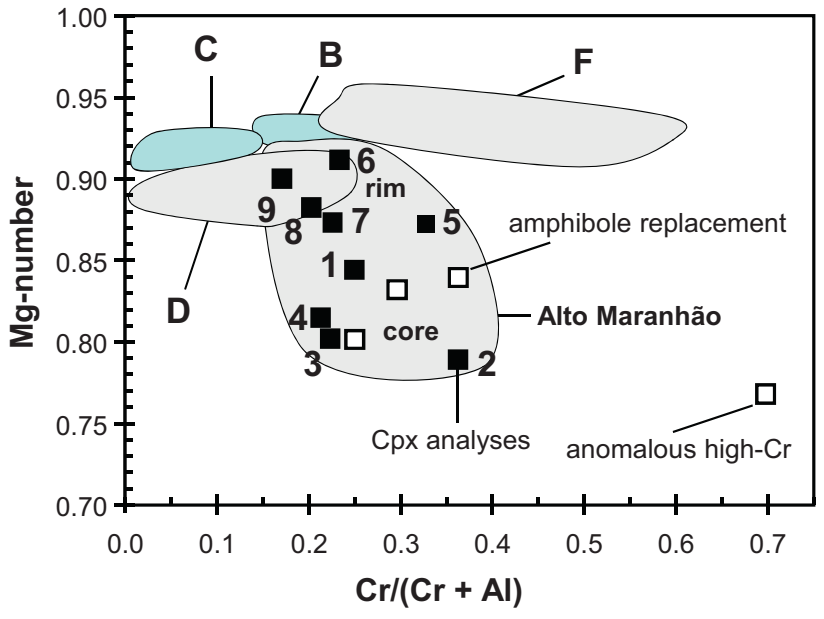

Fig. 12. Composition of the clinopyroxene xenocryst from the Alto Maranhão suite in terms of Mg-number versus $\mathrm{Cr}$-number. The data are compared with compositions of clinopyroxenes within mantle peridotites (F) and within adakites (B and C) and high-Mg andesites (D). Source of data: (F) clinopyroxenes from the Finero complex, a phlogopite-bearing peridotite massif modified by subduction-related metasomatic processes ( $n=15$, from Zanetti et al., 1999, Tables 1 and 2); (B) and (C) clinopyroxene xenocrysts within, respectively, the Burney $(n=5)$ and Cook Island $(n=9)$ Holocenic adakitic andesites, Andean Austral Volcanic Zone (Stern and Kilian, 1996, Fig. 3); (D) clinopyroxene in ultramafic xenoliths and clinopyroxene as xenocrysts incorporated in a Lower Cretaceous high-Mg andesitic dike at Gongen, southern Kitakami, Japan ( $n=14$, from Table 4 of Tsuchiya et al., 2005). For B, C and D occurrences, the clinopyroxenes are attributed to have been derived from the mantle wedge metasomatised by slab-derived melts and which were picked up during the ascent of the host magmas. The labelled analytical points of the Alto Maranhão suite are according to Fig. 4 and Table 3. Grey squares refer to composition of amphibole replacements into the clinopyroxene (labelled as $a$ in Fig. 4), with an anomalous high $\mathrm{Cr}$-result also included.

component formed by partial crystallization of a melt, after which the remaining melt was extracted from the system of interest. Field evidence shows that most of the enclaves do not have medium grained textures typical of layered rocks. By contrary, fine-grained samples predominate, and there is evidence of widespread occurrence of apatite needles typical of quenching liquids (Vernon, 1991). This is also demonstrated by the independent trends of tonalites and MME in diagrams of wt.\% $\mathrm{CaO}$ versus $\mathrm{Rb}, \mathrm{Ce}, \mathrm{P}$ and $\mathrm{Zr}$ (Fig. 15), which reflect the role of, respectively, biotite, allanite, apatite and zircon as either fractionating (in tonalitic magmas), or early crystallized cumulative phases (in dioritic MME). In fact, this graph shows that the most evolved tonalitic samples were "distilled" from the accessory minerals components lefts behind in the primitive samples. By contrary, the least siliceous enclaves have had these same components incorporated after an initial composition like that of the samples E1/E2.

The widespread distribution of mingling structures between tonalite and MME indicates that both materials coexisted in bimodal magmatic chambers composed of intermediate felsic tonalitic magmas recharged episodically by mafic high-Mg dioritic hydrous liquids. Mixing textures observed in the field result from transfer of plagioclase phenocrysts from tonalite to MME (Fig. 2), indicating that plagioclase was probably not a liquidus phase in the dioritic MME magma when it began to crystallize in the tonalitic chamber. This is supported by petrographic evidence of hornblende found as inclusions within plagioclase. Subsequently, tonalitic and MME magmas evolved as independent but cogenetic liquids with limited mixing, mainly by fractional crystallization of hornblende and accessory minerals. The variable proportions of felsic mineralogy (essentially plagioclase) in MME are reflected by scattered distributions of $\mathrm{CaO}, \mathrm{Al}_{2} \mathrm{O}_{3}$ and $\mathrm{Sr}$ in Harker-like diagrams (Fig. 8). Higher $\mathrm{K}_{2} \mathrm{O}$ contents and higher $\mathrm{K}_{2} \mathrm{O} / \mathrm{Na}_{2} \mathrm{O}$ ratios in the least siliceous MME (Fig. 7d and e) reflect higher volumes of 
(a)

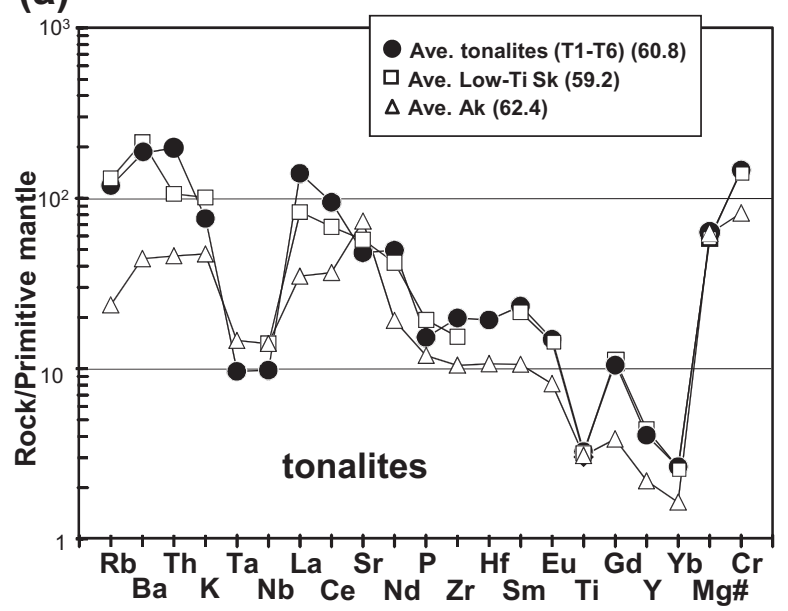

(c)

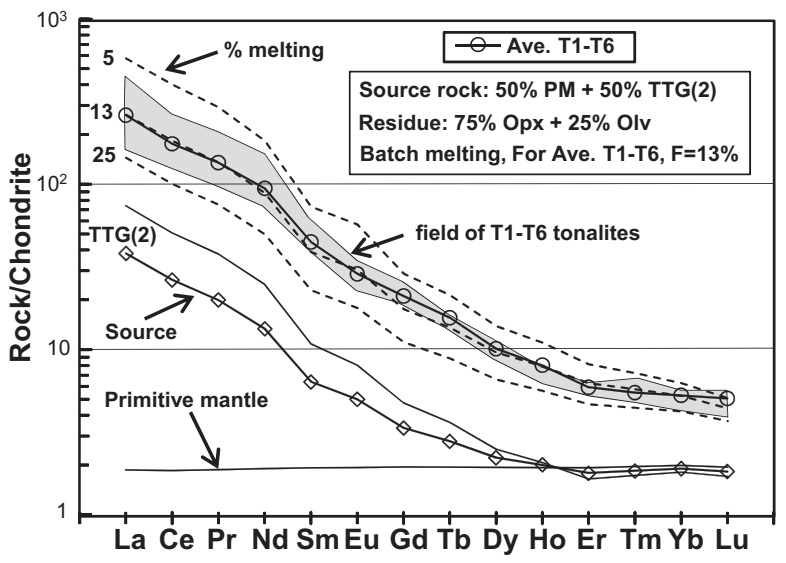

(b)

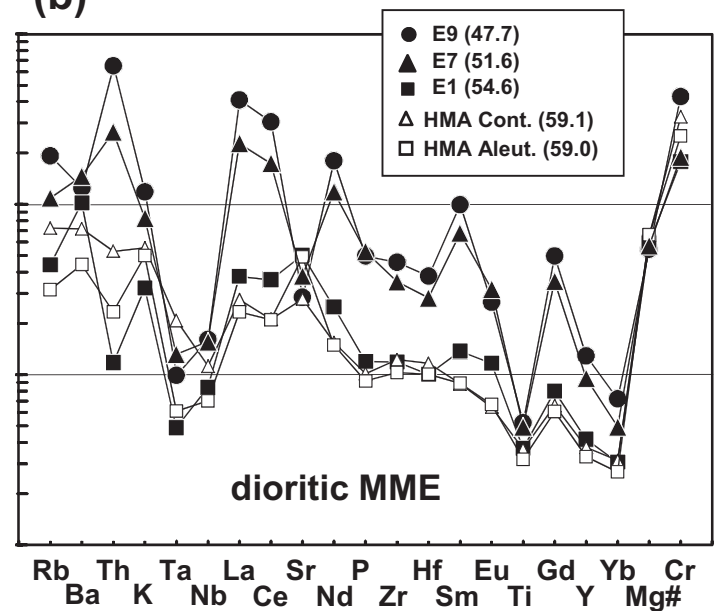

(d)

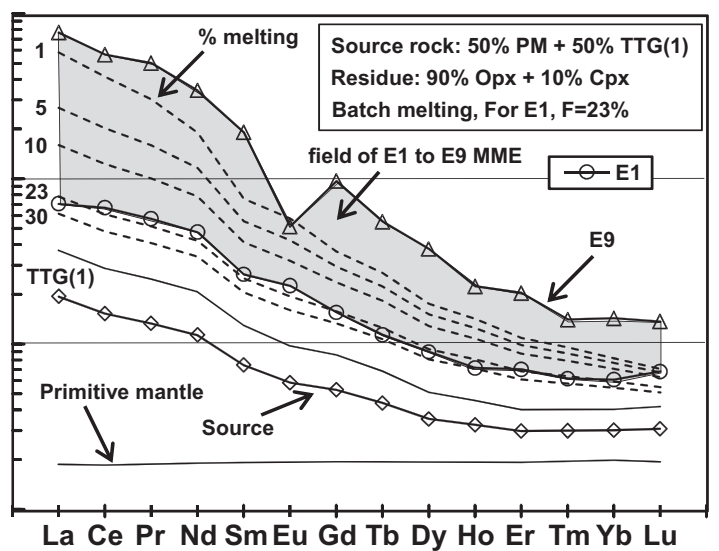

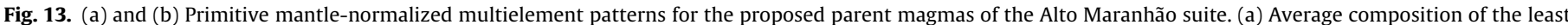

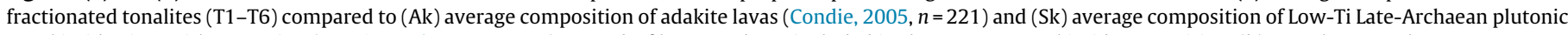

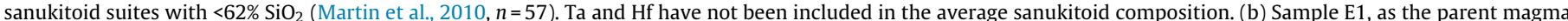

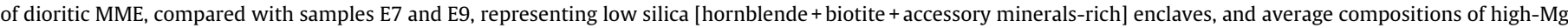

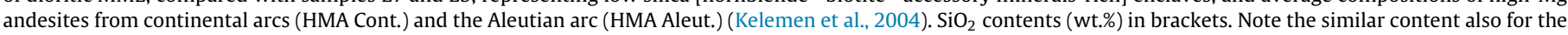

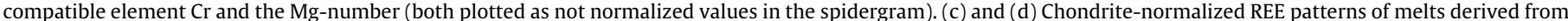

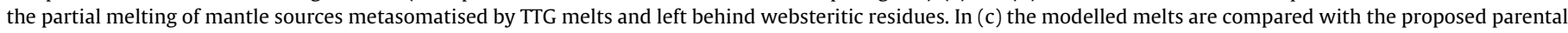

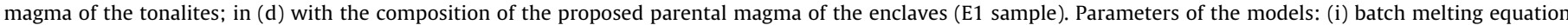

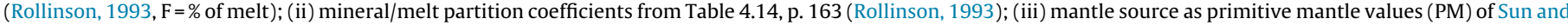

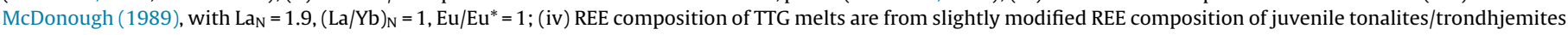

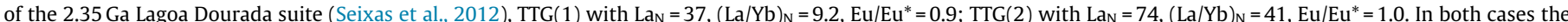

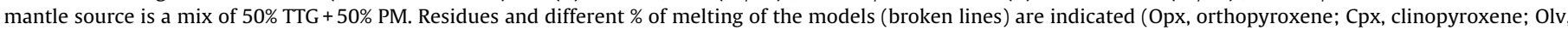
olivine).

biotite \pm mangesiohornblende, and not of plagioclase. The absence of plagioclase as a liquidus phase in the Alto Maranhão suite could be a consequence of the highly hydrous nature of parent magmas, as it was suggested in the case of amphibole-dominated plutonic rocks at the base of subduction-related magmatic arcs (Tatsumi and Ishizaka, 1982; Müntener et al., 2001; Tiepolo and Tribuzio, 2008).

Another particular aspect of the magmatic evolution of the suite is the role exerted by the coupled crystallization of allanite and hornblende. The effect of allanite crystallization is illustrated by chondrite-normalized REE patterns and in light/heavy REE ratios against wt.\% $\mathrm{SiO}_{2}$ and/or $\Sigma$ REE diagrams (Fig. 9a, b and e). For the MME, the observed synchronous increases in $(\mathrm{La} / \mathrm{Yb})_{N}$ ratios and $\Sigma$ REE (ppm) associated with a silica decrease can be attributed to allanite accumulation (Fig. 9b and e, tie samples E1-E9). In the case of tonalites, the effect of fractional crystallization of allanite can be deduced by observed synchronous decreases in $(\mathrm{La} / \mathrm{Yb})_{\mathrm{N}}$ ratio and $\mathrm{REE}$ (ppm) associated with silica increases (Fig. 9a and e, samples
T2-T14 and T15). Likewise, the effect of magnesiohornblende crystallization is illustrated by increasing $\mathrm{A} / \mathrm{CNK}$ indices following silica increases in both tonalites and MME (Fig. 7f), as well as by higher chromium contents in the most mafic MME and tonalites, taking in account the high $K_{\mathrm{D}}$ mineral/melt of chromium to magnesiohornblende in basaltic andesites and andesitic liquids (Rollinson, 1993) and that this mineral is the early crystallized mafic phase in these lithologies (Figs. 2b and 8).

Moreover, Fig. 16 illustrates the effect of simultaneous crystallization of both minerals in the trace elements contents of the suite. The graphs are based in the correlation of the chondrite-normalized $\mathrm{Eu} / \mathrm{Eu}^{*}$ anomalies and of the $\mathrm{Sr} / \mathrm{Sr}^{*}$ anomalies (calculated from neighbouring $\mathrm{Ce}$ and $\mathrm{Nd}$ abundances in primitive mantlenormalized diagrams) plotted against the chondrite-normalized $\mathrm{La} / \mathrm{Sm}$ and $\mathrm{Gd} / \mathrm{Yb}$ ratios (respectively Fig. 16a and b). The figure is complemented by the chondrite-normalized REE (Fig. 16c) and primitive mantle-normalized profiles (Fig. 16d). Two independent 


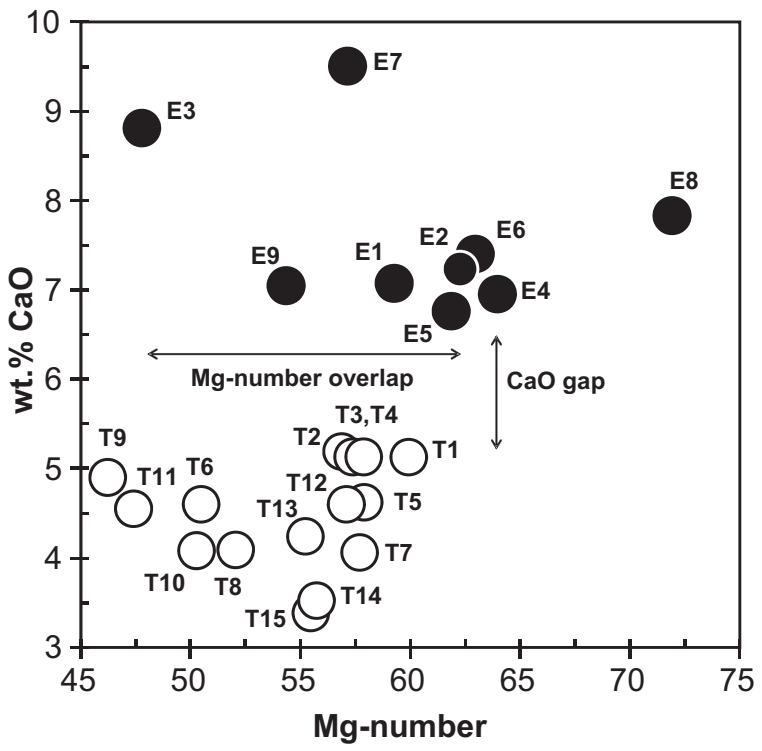

Fig. 14. $\mathrm{CaO}$ (wt.\%) versus Mg-number diagram of tonalites and dioritic MME. Symbols as in Fig. 7. The CaO gap implies that tonalites and dioritic MME are not hybrid terms and have evolved from distinct parent magmas.

liquid lines of descent reflect different starting compositions. The MME trend "progresses" from the sample E1, which is the presumed parent magma, to the most mafic and REE-rich enclaves E7 and E9 attaining higher $(\mathrm{La} / \mathrm{Sm})_{\mathrm{N}}$ and $(\mathrm{Gd} / \mathrm{Yb})_{\mathrm{N}}$ ratios coupled with the change from positive to increasingly negative $\mathrm{Sr} / \mathrm{Sr}{ }^{*}$ and $\mathrm{Eu} / \mathrm{Eu}^{*}$ anomalies (respectively Fig. 16a and b). This trend is interpreted as the result of [hornblende + allanite] accumulation due to the lower $K_{\mathrm{D}}$ mineral/melt of $\mathrm{Sr}$ relative of light REE (i.e. $\mathrm{Nd}$ and $\mathrm{Ce}$ ) and of Eu relative of middle REE (i.e. Sm and Gd) in both minerals (see for example compilation of $K_{\mathrm{D}} \mathrm{S}$ in Rollinson, 1993 and/or in Bédard, 2006). In the case of allanite, any small percentage of crystal accumulation in an already light/heavy REE fractionated magma - as is the E1 parental magma (see Fig. 9b), and not accompanied by increasing volumes of plagioclase - as is indicated by the modal composition of the samples E1, E7 and E9 (Table 1), could be very effective in promoting and/or increasing the negative $\mathrm{Sr} / \mathrm{Sr}^{*}$ and $\mathrm{Eu} / \mathrm{Eu}^{*}$ anomalies because of the much higher $K_{\mathrm{D}}^{\text {allanite-melt }}$ of the light REE relative to $\mathrm{Sr}$, as also of the middle REE relative to Eu. Otherwise, the tonalite trend starts with the most primitive tonalites (average $\mathrm{T} 1-\mathrm{T} 6,60.8 \mathrm{wt} . \% \mathrm{SiO}_{2}$ ) and "progresses" towards the more evolved rocks (average T7-T15, $63.5 \mathrm{wt} . \% \mathrm{SiO}_{2}$ ), which yield lower values of $(\mathrm{La} / \mathrm{Sm})_{\mathrm{N}}$ and $(\mathrm{Gd} / \mathrm{Yb})_{\mathrm{N}}$ ratios, along with $\mathrm{Sr} / \mathrm{Sr}^{*}$ anomalies evolving from negative to positive values. Evolved tonalite compositions are interpreted as representing residual liquids derived from allanite and hornblende fractionation from the most primitive samples, these primitive samples showing higher values of $(\mathrm{La} / \mathrm{Sm})_{\mathrm{N}}$ and $(\mathrm{Gd} / \mathrm{Yb})_{\mathrm{N}}$ ratios and lower values of $\mathrm{Sr} / \mathrm{Sr}^{*}$ anomalies (Fig. 16).

Rayleigh fractional crystallization models based in the REE were applied to test these findings, and are also indicated in Fig. 16a and c. Good fits for the fractional crystallization of the tonalites, from a $L_{0}$ composition represented by the average of the least fractionated (T1-T6) samples to a residual composition $L_{R}$ represented by the average of the most evolved (T7-T15) samples, have been acquired comprising assemblages of cumulates largely dominated by hornblende, with or without biotite [respectively model (b) and model (a)]. In both cases, accessory minerals Aln, Ap and $\mathrm{Zrn}$ are required components. In particular, the presence of allanite in the early precipitated solids contributes to the changing values of $\mathrm{Eu} / \mathrm{Eu}^{*}$ and $\mathrm{Sr} / \mathrm{Sr}^{*}$ anomalies seen in the chondriteand primitive mantle-normalized profiles of the derived liquids (respectively Fig. 16a and c, and Fig. 16b and d). The percentage of fractional crystallization required attains $40 \%$. These models are in accord with fractional crystallization of tonalitic suites containing allanite (e.g., Martin, 1987; Bédard, 2006). The fractional crystallization of the enclaves was tested subtracting from the E1 sample $\left(L_{0}\right)$ a cumulate assemblage which reproduces approximately the modal composition of the sample E9, and the mirroring REE profiles of the residual liquids with the measured enclaves samples corroborate the model and the proposition that the most enriched enclave sample of the collection investigated in this study could result from the early accumulation of mafic (hornblende + biotite) and accessory (allanite + apatite + zircon) minerals, in the absence of plagioclase ( $\mathrm{Sr}$ depletion). Other accessory phases (i.e. ilmenite and $\mathrm{Fe}-\mathrm{Ni}-\mathrm{Cu}$ sulphides) which have also precipitated early from the mafic magma have no major influence in the REE contents of the rocks.

\subsection{Petrotectonic setting}

The Alto Maranhão suite represents a major episode of juvenile, intermediate mafic to felsic, mantle-derived, plutonic addition of crust that occurred ca. $2130 \mathrm{Ma}$ ago in the Mineiro Belt, in the southern margin of the São Francisco craton. The geochemistry and Nd isotopic composition of the suite are consistent with an
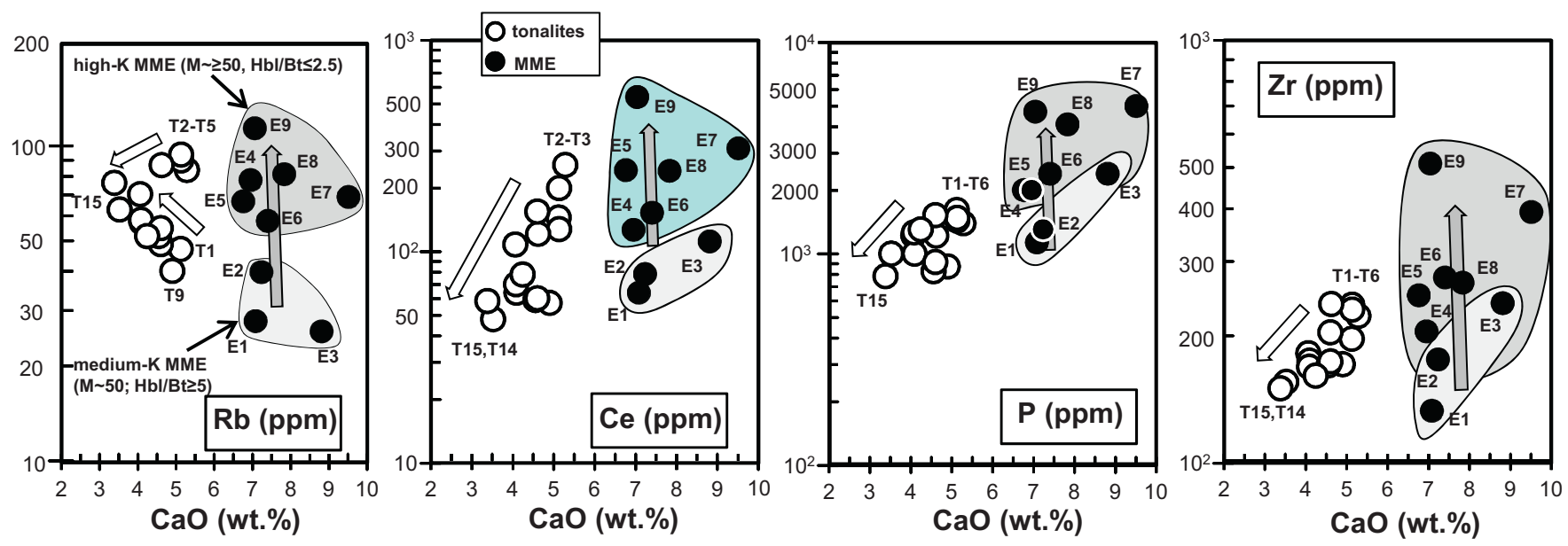

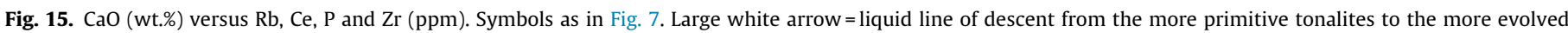
compositions (T15, T14); grey arrow = crystal accumulation trend in dioritic MME from E1 to E9. See text for explanation. 
(a)

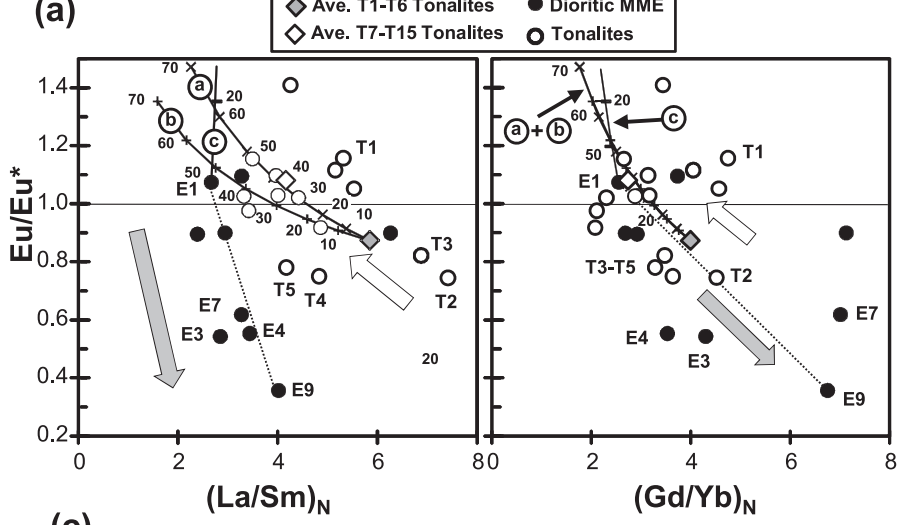

(c)

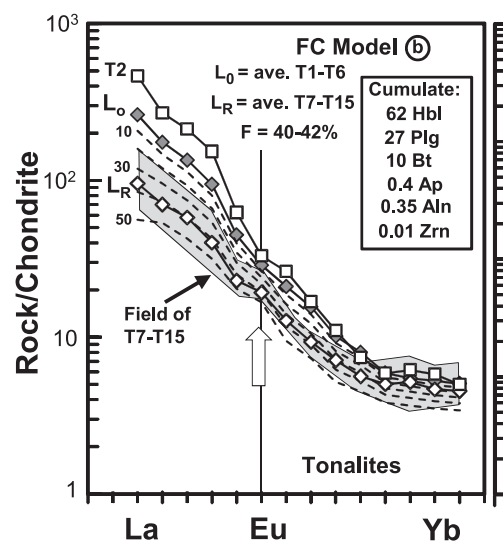

(b)

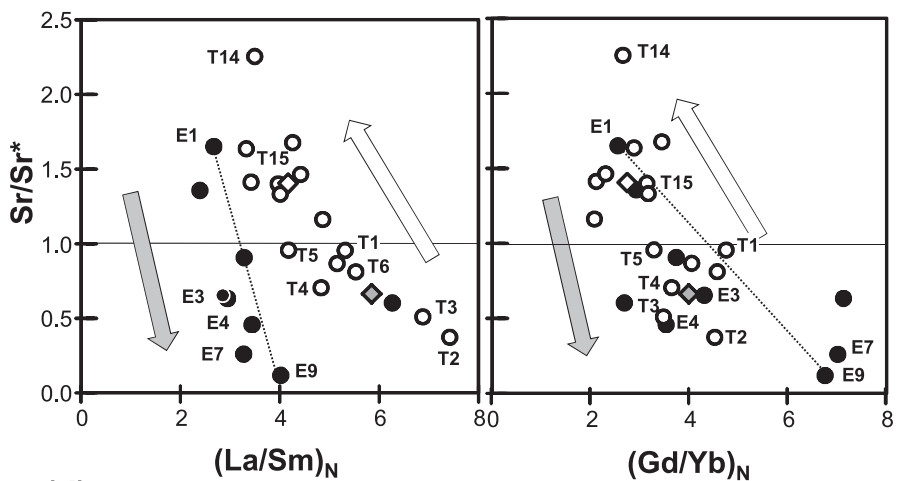

(d)

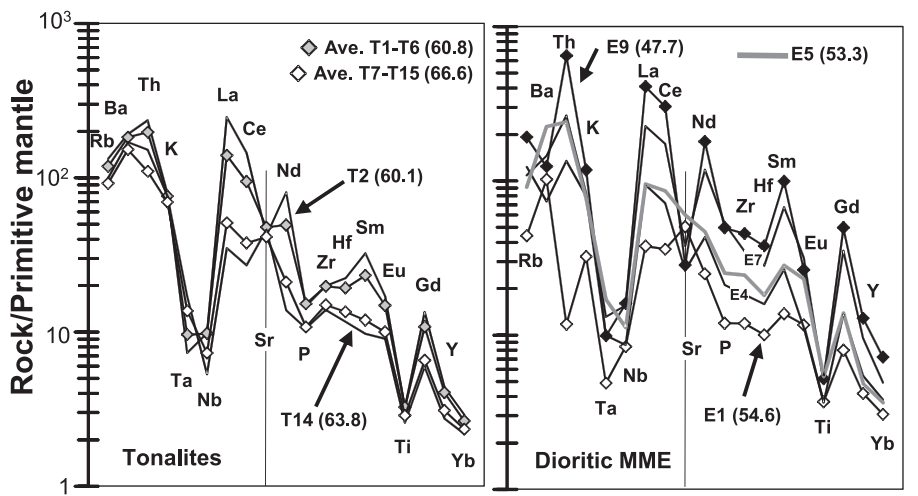

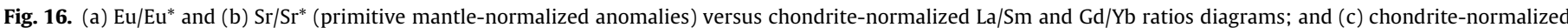

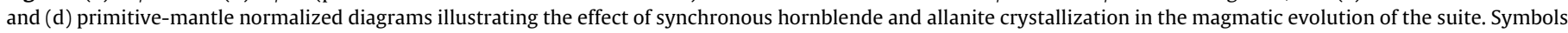

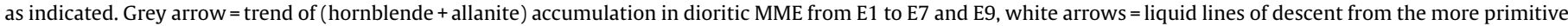

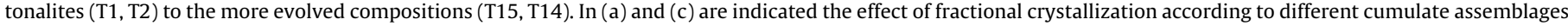

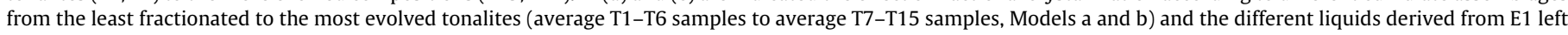

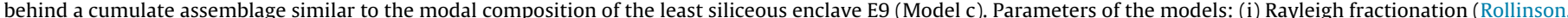

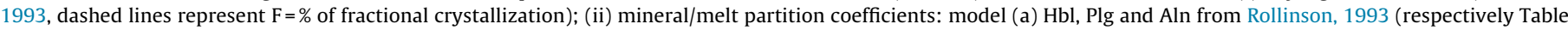

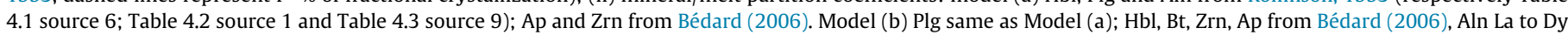

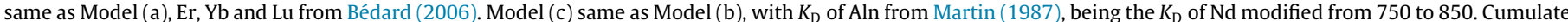

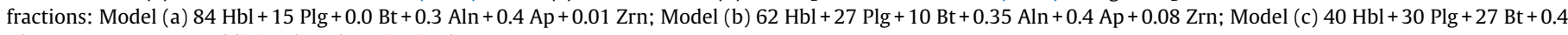
$\mathrm{Aln}+2.6 \mathrm{Ap}+0.1 \mathrm{Zrn}$. Additional explanation in the text.

origin from melting of a metasomatised mantle wedge beneath a volcanic arc, corroborating the hypothesis of subduction-related setting for Rhyacian granite petrogenesis in the region (Alkmim and Marshak, 1998; Noce et al., 2000; Ávila et al., 2010). Geochemical and mineralogical data support a mantle source for the Alto Maranhão suite, which was metasomatised by interaction with liquids derived from the partial melting of tholeiitic oceanic crust (e.g., high-aluminium TTG melts). This scenario reproduces the models adopted for the petrogenesis of Late-Archaean mantle-derived high-Mg granitoid (sanukitoids) suites, in which mantle-derived suites postdate high-aluminium TTG suites (Martin et al., 2010; Rapp et al., 2010). Evidence for an earlier (i.e. >2.13 Ga) juvenile high-aluminium TTG crust formation event in the northern sector of Mineiro Belt includes the ca. 2350 Ma Lagoa Dourada TTG suite (Seixas et al., 2012, see Fig. 1 for location). In fact, the partial melting models which were tested for the proposed metasomatised mantle source of the suite have adopted as the TTG melt components REE compositions like that of the tonalites/trondhjemtites of the Lagoa Dourada TTG suite. The REE partial melting models of these TTG melts suppose garnet amphibolites to amphibole eclogitic residues, and hence that they have been generated at depths greater than 40-60 km (Seixas et al., 2012). At these depths in a convergent setting these melts could readily be the agent of mantle wedge metasomatism (Martin et al., 2010). However, the Lagoa Dourada
TTG suite yields no evidence of assimilation of and/or interaction with the upper mantle during their ascent and emplacement into the crust, suggesting that this suite was formed in an intra-oceanic setting at the early beginning of the Paleoproterozoic orogenies of the Mineiro Belt. Therefore, these two igneous (tonalitic) juvenile suites of the Mineiro Belt could then illustrate a shift from a convergent intra-oceanic tectonic setting at $2.35 \mathrm{Ga}$ (with no mantle wedge imprint in the TTG magmas) to a continental arc setting at $\sim 2.13 \mathrm{Ga}$ (with the effective participation of the mantle wedge in the genesis of the tonalites). This model reproduces the suggested convergent plate boundary setting for the genesis of the sanukitoid suites at the Archaean-Proterozoic transition period (Martin et al., 2010). If these tectonic settings are correct, then the emplacement the Alto Maranhão suite must have occurred after a prolonged period of oceanic crust consumption in the Paleoproterozic.

\section{Conclusions}

The petrogenesis of the ca. 2130 Ma Alto Maranhão suite provides new insights into crustal growth processes related to the 2.2-2.1 Ga Rhyacian orogenesis in the southern São Francisco craton of Brazil. It is proposed that the suite formed by the melting of the mantle wedge below a Paleoproterozoic arc that had been metasomatised by interaction with low-degree partial melts from 
the subducted slabs. The inferred parent magma is a high-Mg tonalitic liquid equivalent to arc-related high-Mg andesites. It mingled locally in a sub-arc environment with more mafic and primitive high-Mg dioritic liquids that crystallized ultimately as fine-grained dioritic mafic magmatic enclaves (MME) and/or synplutonic dikes. Partial melting modelling suggests that the mantle source for both magmas was similar, consisting of primitive mantle metasomatised by TTG-like melts and left behind Opx-rich websteritc residues ( $\pm \mathrm{Cpx}$ or Olv). Igneous emplacement is envisaged to have occurred at mid-crustal depth in a thick-arc crust generated during a protracted period of oceanic crust consumption. Geochemical variations of the members of the suite are likely the result of crystallization under moderate $\mathrm{fO}_{2}$ conditions buffered by assemblages containing $\mathrm{Fe}-\mathrm{Ti}$ oxides $+\mathrm{Fe}-\mathrm{Ni}-\mathrm{Cu}$ sulphides + allanite at low- to mid-crustal depths. Igneous trends were controlled by fractional crystallization of magnesiohornblende, biotite and accessory minerals (allanite, zircon, apatite and Fe-Ti oxides), with plagioclase being a late mineral phase. Late crystallization of plagioclase in the more mafic members of the suite can explain why dioritic MME consist mainly of cumulate [hornblende + biotite + accessory minerals] rocks. This study provides further evidence for a major ca. $2.13 \mathrm{Ga}$ crust forming event that added intermediate to felsic juvenile continental crust to the São Franscico craton.

\section{Acknowledgements}

The first author thanks the staff of the Laboratoire de Pétrographie-Volcanologie/Université Paris-Sud (France) and the GEOTOP/Université du Québec à Montréal (Canada) for providing first-class technical and analytical support. Professor François Bussy (Lausanne University, Switzerland) gently provided microprobe facilities for the REE analyses of allanite, apatite and zircon. This research was partially supported by a CAPES/Brasília-Brazil fellowship (processes 0918-08-0 and 0716-96) and a FAPEMIG/Minas Gerais-Brazil research grant (process CRA 440/02) to LARS. RS was supported by a NSERC Discovery Grant. The first author thanks Prof. Edison Tazava (UFOP) for helping in the opaque mineralogy under the reflection light microscope. The comments and criticism of the two anonymous reviewers have contributed to the improvement of the original version of the manuscript and are gratefully appreciated.

\section{References}

Abdel-Rahman, A.F.M., 1994. Nature of biotites from alkaline, calc-alkaline, and peraluminous magmas. Journal of Petrology 35, 525-541.

Alkmim, F.F., Marshak, S., 1998. Transamazonian orogeny in the southern São Francisco craton region, Minas Gerais, Brazil: evidence for Paleoproterozoic collision and collapse in the Quadrilátero Ferrífero. Precambriam Research 90, $29-58$

Almeida, F.F.M., Neves, B.B.B., Carneiro, C.D.R., 2000. The origin and evolution of the South American platform. Earth Science Reviews 50, 77-111.

Anderson, J.L., Smith, D.R., 1995. The effects of temperature and fO2 on the Al-inhornblende barometer. American Mineralogist 80, 549-559.

Ávila, C.A., Teixeira, W., Cordani, U.G., Moura, C.A.V., Pereira, R.M., 2010. Rhyacian $(2.23-2.20 \mathrm{Ga})$ juvenile accretion in the southern São Francisco craton, Brazil: geochemical and isotopic evidence from the Serrinha magmatic suite, Mineiro Belt. Journal of South American Earth Sciences 29, 464-482.

Barker, F., 1979. Trondhjemite: definition, environment and hypotheses of origin. In: Barker, F. (Ed.), Trondhjemites, Dacites and Related Rocks. Elsevier, New York, pp. $1-12$.

Barker, F., Arth, J.G., 1976. Generation of trondhjemitic-tonalitic liquids and Archaean bimodal trondhjemite-basalt suites. Geology 4, 596-600.

Bédard, J.H., 2006. A catalytic delamination-driven model for coupled genesis of Archaean crust and sub-continental lithospheric mantle. Geochimica and Cosmochimica Acta 70, 1188-1214.

Brito Neves, B.B., 2011. The Paleoproterozoic in the South-American continent: diversity in the geologic time. Journal of South American Earth Sciences 32, 270-286.

Clemens, J.D., Yearron, L.M., Stevens, G., 2006. Barberton (South Africa) TTG magmas: geochemical and experimental constraints on source-rock petrology, pressure of formation and tectonic setting. Precambriam Research 151, 53-78.
Condie, K.C., 2005. TTGs and adakites: are they both slab melts? Lithos 80, 33-44.

Condie, K.C., Belousova, E., Griffin, W.L., Sircombe, K.N., 2009. Granitoid events in space and time: constraints from igneous and detrital zircon age spectra. Gondwana Research 15, 228-242.

Cordani, U.G., Sato, K., 1999. Crustal evolution of the South American Platform, based on Nd isotopic systematics on granitoid rocks. Episodes 22, 167-173.

DePaolo, D.J., 1981. Neodymium isotopes in the Colorado Front Range and crust-mantle evolution in the Proterozoic. Nature 291, 193-196.

Didier, J., Barbarin, B., 1991. Enclaves and Granite Petrology. Elsevier, Amsterdam.

Droop, G.T.R., 1987. A general equation for estimating Fe ${ }^{3+}$ concentrations in ferromagnesian silicates and oxides from microprobe analyses using stoichiometric criteria. Mineralogical Magazine 51, 431-435.

Drummond, M.S., Defant, M.J., 1990. A model for trondhjemite-tonalite-dacite genesis and crustal growth via slab melting: Archean to modern comparisons. Journal of Geophysical Research 95, 21503-21521.

Evans, O.C., Hanson, G.N., 1997. Late- to post-kinematic Archaean granitoids of the S.W. Superior province: derivation through direct mantle melting. In: De Wit, M.J., Ashwal, L.D. (Eds.), Greenstone Belts. Clarendon Press, Oxford, pp. 280-295.

Gieré, R., Sorensen, S.S., 2004. Allanite and other REE-rich epidote-group minerals. Reviews in Mineralogy \& Geochemistry 56, 431-493.

Heilimo, E., Halla, J., Hölttä, P.P., 2010. Discrimination and origin of the sanukitoid series: geochemical constraints from the Neoarchean western Karelian Province (Finland). Lithos 115, 27-39.

Irvine, T.N., Baragar, W.R.A., 1971. A guide to the chemical classification of the common volcanic rocks. Canadian Journal of Earth Sciences 8, 523-548.

Ishihara, S., 1977. The magnetite-series and ilmenite-series granitic rocks. Mining Geology 27, 293-305.

Kelemen, P.B., Hanghoj, K., Greene, A.R., 2004. One view of the geochemistry of subduction-related magmatic arcs, with an emphasis on primitive andesite and lower crust. In: Rudnick, R.L. (Ed.), Treatise on Geochemistry, The Crust. Elsevier, San Diego, pp. 593-659.

Kepezhinskas, P.K., Defant, M.J., Drummond, M.S., 1995. Na metasomatism in the island arc mantle by slab melt-peridotite interaction: evidence from mantle xenoliths in the north Kamchatka arc. Journal of Petrology 36, 1505-1527.

Krogh, T.E., 1973. A low-contamination method for hydrothermal decomposition of zircon and extraction of $\mathrm{U}$ and $\mathrm{Pb}$ for isotopic age determinations. Geochimica and Cosmochimica Acta 37, 485-494.

Leake, B.E., et al., 1997. Nomenclature of amphiboles: report of the subcommittee on amphiboles of the International Mineralogical Association Commission on new minerals and mineral names. Mineralogical Magazine 61, 295-321.

Le Maitre, R.W. (Ed.), 2002. Igneous Rocks, A Classification and Glossary of Terms Recommendations of the International Union of Geological Sciences Subcommission on the Systematics of Igneous Rocks. Cambridge University Press, Cambridge, UK.

Lobach-Zhuchenko, S.B., Rollinson, H.R., Chekulaev, S. V.P., Kovalenko, V.M., Martin, H., Guseva, N.S., Arestova, N.A., 2008. Petrology of a Late Archaean, highly potassic, sanukitoid pluton from the Baltic Shield: insights into Late Archaean mantle metasomatism. Journal of Petrology 49, 393-420.

Ludwig, K.R., 1993. PBDAT. A Computer Program for Processing Pb-U-Th Isotope Data. USGS Open File Report 34., pp. 88-542.

Ludwig, K.R., 2001a. Squid 1.02. A User's Manual. BGC Special Publication 2, Berkeley, pp. 19.

Ludwig, K.R., 2001b. User's Manual for Isoplot/Ex v. 2.47. A Geochronological Toolkit for Microsoft Excel. BGC Special Publication 1a, Berkeley, pp. 55.

Martin, H., 1987. Petrogenesis of Archaean trondhjemites, tonalites and granodiorites from Eastern Finland: major and trace element geochemistry. Journal of Petrology 28, 921-953.

Martin, H., Moyen, J.-F., Rapp, R., 2010. Sanukitoids and the Archaean-Proterozoic boundary. Transactions of the Royal Society of Edinburgh-Earth Sciences 100 15-33.

Martin, H., Smithies, R.H., Rapp, R., Moyen, J.-F., Champion, D., 2005. An overview of adakite, tonalite-trondhjemite-granodiorite (TTG), and sanukitoid: relationships and some implications for crustal evolution. Lithos 79, 1-24.

Moyen, J.-F., Martin, H., Jayananda, M., 2001. Multi-element geochemical modelling of crust-mantle interactions during late-Archaean crustal growth: the Closepet granite (South India). Precambrian Research 112, 87-105.

Morimoto, N., 1988. Nomenclature of pyroxenes. Mineralogical Magazine 52, 535-550.

Müntener, O., Kelemen, P.B., Grove, T.L., 2001. The role of $\mathrm{H}_{2} \mathrm{O}$ during crystallization of primitive arc magmas under uppermost mantle conditions and genesis of igneous pyroxenites: an experimental study. Contributions to Mineralogy and Petrology 141, 643-658.

Noce, C.M., 1995. Geocronologia dos Eventos Magmáticos, Sedimentares e Metamórficos na Região do Quadrilátero Ferrífero, Minas Gerais. Universidade de São Paulo, pp. 128 (PhD thesis).

Noce, C.M., Teixeira, W., Queménéur, J.J.G., Martins, V.T.S., Bolzaquini, E., 2000. Isotopic signatures of Paleoproterozoic granitoids from the southern São Francisco Craton and implications for the evolution of the Transamazonian Orogeny. Journal of South American Earth Sciences 13, 225-239.

O'Connor, J.T., 1965. A Classification for Quartz-rich Igneous Rocks Based on Feldspar Ratios. U.S. Geol. Surv. Prof. Paper 525-B., pp. 79-84.

Oliveira, M.A., Dall'Agnol, R., Almeida, J.A.C., 2011. Petrology of the Mesoarchean Rio Maria suite and the discrimination of sanukitoid series. Lithos 127, 192-209.

Pimentel, M.M., Charnley, N., 1991. Intracrustal REE fractionation and implications for Sm-Nd model age calculations in late-stage granitic rocks: an example from central Brazil. Chemical Geology (Isotope Geoscience Section) 86, 123-138. 
Rapp, R.P., 1997. Heterogeneous source regions for Archaean granitoids: experimental and geochemical evidence. In: De Wit, M.J., Ashwal, L.D. (Eds.), Greenstone Belts. Clarendon Press, Oxford, pp. 267-279.

Rapp, R.P., Norman, M.D., Laporte, D., Yaxley, G.M., Martin, H., Foley, S.F., 2010. Continent formation in the Archean and chemical evolution of the cratonic lithosphere: melt-rock reaction experiments at 3-4 GPa and petrogenesis of Archean Mg-diorites (sanukitoids). Journal of Petrology 51, 1237-1260.

Rapp, R.P., Watson, E.B., 1995. Dehydration melting of metabasalt at 8-32 kbar: implications for continental growth and crust-mantle recycling. Journal of Petrology 36, 891-931.

Richard, P., Shimizu, N., Allègre, C.J., $1976 .{ }^{143} \mathrm{Nd} /{ }^{144} \mathrm{Nd}$, a natural tracer: an application to oceanic basalts. Earth and Planetary Science Letters 31, 269-278.

Rollinson, H., 1993. Using Geochemical Data: Evaluation, Presentation, Interpretation. New York, Longman.

Schmidt, M.W., 1992. Amphibole composition in tonalite as a function of pressure: an experimental calibration of the Al-in-hornblende barometer. Contributions to Mineralogy and Petrology 110, 304-310.

Schmidt, M.W., Poli, S., 2004. Epidote. Reviews in Mineralogy \& Geochemistry 56, 399-430.

Schmidt, M.W., Thompson, A.B., 1996. Epidote in calc-alkaline magmas: an experimental study of stability, phase relationships, and the role of epidote in magmatic evolution. American Mineralogist 81, 462-474.

Seixas, L.A.R., 2000. Pétrologie de la suite TTG de la bordure nord du batholite d'Alto Maranhão et du pluton Congonhas, Minas Gerais, Brésil. Université de Paris-Sud, Orsay, Ph.D. thesis, 202 pp.

Seixas, L.A.R., David, J., Stevenson, R., 2012. Geochemistry, Nd isotopes and U-Pb geochronology of a 2350 Ma TTG suite, Minas Gerais Brazil: implications for the crustal evolution of the southern São Francisco craton. Precambrian Research 196-197, 61-80.

Seixas, L.A.R., Hippertt, J., Bardintzeff, J.-M., Bonin, B., 2000. Petrology of the Alto Maranhão tonalite-granodiorite-trondhjemite batholith and the intruded meta-komatiites, south of Quadrilátero Ferrífero Greenstone Belt, Minas Gerais, Brazil. In: 31st International Geological Congress, Rio de Janeiro, Brazil, August 6-17, 2000.

Shimizu, M., 1986. The Tokuwa Batholith, Central Japan-An Example of Occurrence of Ilmenite-series and Magnetite-series Granitoids in a Batholith. University Museum, University of Tokyo Bulletin, 28, 143p.

Shirey, S.B., Hanson, G.N., 1984. Mantle derived Archaean monzodiorites and trachyandesites. Nature 310, 222-224.

Smithies, R.H., Champion, D.C., 2000. The Archaean high-Mg diorite suite: links to tonalite-trondhjemite-granodiorite magmatism and implications for early Archaean crustal growth. Journal of Petrology 41, 1653-1671.

Stern, R.A., Hanson, G.N., 1991. Archean high-Mg granodiorite: a derivative of light rare earth element-enriched monzodiorite of mantle origin. Journal of Petrology 32, 201-238
Stern, C.R., Kilian, R., 1996. Role of subducted slab, mantle wedge and continental crust in the generation of adakites from the Austral Volcanic Zone. Contributions to Mineralogy and Petrology 123, 263-281.

Stevenson, R.K., Henry, P., Gariépy, C., 1999. Assimilation-fractional crystallization origin of Archean Sanukitoid Suites: Western Superior province, Canada. Precambrian Research 96, 83-99.

Stormer Jr., J.C., 1983. The effects of recalculation on estimates of temperatures and oxygen fugacity from analyses of multicomponent iron-titanium oxides. American Mineralogist 68, 586-594.

Streckeisen, A., 1976. To each plutonic rock its proper name. Earth Science Reviews $12,1-33$.

Sun, S.-S., McDonough, W.F., 1989. Chemical and isotopic systematics of oceanic basalts: implications for mantle compositions and processes. In: Saunders, A.D. Norry, M.J. (Eds.), Magmatism in the Ocean Basins. Geological Society Special Publication, 42. , pp. 313-345.

Sutcliffe, R.H., Smith, A.R., Doherty, W., Barnett, R.I., 1990. Mantle derivation of Archean amphibole-bearing granitoid and associated mafic rocks: evidence from the southern Superior Province, Canada. Contributions to Mineralogy and Petrology 105, 255-274.

Tanaka, T., Togashi, S., Kamioka, H., Amakawa, H., Kagami, H., Hamamoto, T., Yuhara, M., Orihashi, Y., Yoneda, S., Shimizu, H., Kunimaru, T., Takahashi, K., Yanagi, T., Nakano, T., Fujimaki, H., Shinjo, R., Asahara, Y., Tanimizu, M., Dragusanu, C., 2000. JNdi-1: a neodymium isotopic reference in consistency with LaJolla neodymium. Chemical Geology 168, 279-281.

Tatsumi, Y., Ishizaka, K., 1982. Origin of high-magnesian andesites in the Setouchi volcanic belt, southwest Japan. I. Petrographical and chemical characteristics. Earth and Planetary Science Letters 60, 293-304.

Taylor, S.R., McLennan, S.M., 1985. The Continental Crust: Its Composition and Evolution. Oxford, Blackwell.

Tiepolo, M., Tribuzio, R., 2008. Petrology and U-Pb zircon geochronology of amphibole-rich cumulates with sanukitic affinity from Husky Ridge (Northern Victoria Land, Antarctica): insights into the role of amphibole in the petrogenesis of subduction-related magmas. Journal of Petrology 49, 937-970.

Tsuchiya, N., Suzuki, S., Kimura, J.-I., Kagami, H., 2005. Evidence for slab melt/mantle reaction: petrogenesis of Early Cretaceous and Eocene high-Mg andesites from the Kitakami Mountains, Japan. Lithos 79, 179-206.

Vernon, R.H., 1991. Interpretation of microstructures of microgranitoid enclaves. In: Didier, J., Barbarin, B. (Eds.), Enclaves and Granite Petrology, Developments in Petrology, vol. 13. Elsevier, Amsterdam, pp. 277-291.

Zanetti, A., Mazuchelli, M., Rivalenti, G., Vannuci, R., 1999. The Finero phlogopite-peridotite massif: an example of subduction-related metasomatism. Contributions to Mineralogy and Petrology 134, 107-122. 